\title{
GOOD GRIEF!
}

CHILDREN AND COMICS

A COLLECTION OF COMPANION ESSAYS

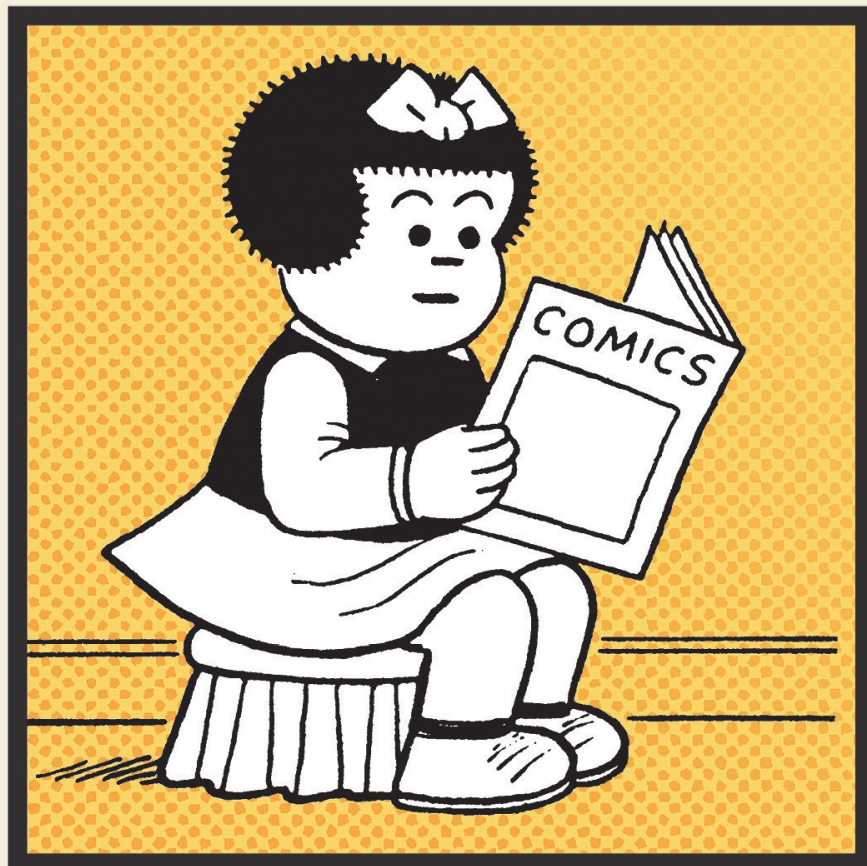

(c) Universal Uclick

To accompany the exhibit at the Billy Ireland Cartoon Library and Museum

June 4 through October 23, 2016

Billy Ireland

CARTOON

Library \& Museum
(1) THE OHIO STATE UNIVERSITY 


\section{Good Grief! Children and Comics}

\section{MICHELLE ANN ABATE AND JOE SUTLIFF SANDERS}

Published by the Billy Ireland Cartoon Library \& Museum in partnership with The Ohio State University Libraries

Columbus, $\mathrm{OH}$ 
A collection of companion essays to accompany the exhibit at the Billy Ireland Cartoon Library \& Museum, June 4 through October 23, 2016. It is published by the Billy Ireland Cartoon Library \& Museum in partnership with the Ohio State University Libraries Publishing Program.

Cover image: Nancy, by Ernie Bushmiller

Copyright 2016, all rights held by the authors This book was produced using PressBooks.com, and PDF rendering was done by PrinceXML. 


\section{Contents}

1. How Comics Became Kids' Stuff Joe Sutliff Sanders

2. "Let's Go Exploring!"

Illustrating Childhood Development in Calvin and Hobbes

fames Curtis

3. Traumatic Origins

Orphanhood and the Superhero

Jennifer Duggan

4. Striking Camp

Empowerment and Re-Presentation in Lumberjanes

Kyle Eveleth

5. The Great American Graphic Novel Jeff Smith's Bone and Its Influences Annette Wannamaker

6. There Are Some Things You Can't Fix with a Magic Wand Politics in Children's Comics

Camila Z. Tessler 
7. The Character in the Mask An Analysis of Mask in Art Spiegelman's Maus Taraneh Matloob Haghanikar

Acknowledgments 


\title{
1. How Comics
}

\section{Became Kids' Stuff}

\author{
Joe Sutliff Sanders
}

You might not remember it, but there was a time when we took for granted that comics were for children. Indeed, if you were born after 1978, when Richard Donner's Superman became the first blockbuster feature-length superhero film in history, you might very reasonably think that superheroes and the other major figures of comic books have always been part of mainstream U.S. culture. Today, it's hard to walk through a chain department store without seeing the likeness of at least one member of the Avengers, even if you avoid the toy section. It's easy to think now that comics and the intellectual properties they spawned have always been standard parts of our culture, that grown-ups should feel no surprise at finding a Batgirl halter top in an adult size or walking into a screening of the latest superhero film alongside an audience composed mostly of adults.

However, if you were born previous to 1978, you probably remember an alternate reality. Before Hollywood discovered that comics can be mined for major cash, the broad consensus was that 
comics were for kids, and adults who read them were considered a little simple. The cereal or candy advertised in the comics featured children happily munching away. The money-making schemes targeted boys and girls-I myself sold a lot of greeting cards because of an ad I saw on the back of an issue of fustice League when I was ten-and the animated shows inspired by comics tended to run after school or on Saturday mornings. Comics thought they were for kids, and so did most of the rest of mainstream culture.

The idea that comics were for children was really an idea that took hold in the middle of the twentieth century. Before that, using words and pictures together to tell a story sequentially was a good way to reach just about anyone who could read. ${ }^{1}$ In fact, no matter where you place the first historical instances of comics-Swiss editorial cartoons? The Bayeux Tapestry? Japanese scrolls with cartoon frogs? Hieroglyphics?-you can easily make the argument that comics have been for a mixed audience of grown-ups and children for much longer than they've been for kids alone.

At what point, then, did comics for children begin?

I'm glad you asked.

\section{The Prehistory of Children's Comics}

As with every art form, comics for children arose from what came before, and in looking at what came before, we can find the pieces of the form that would eventually become comics for children. ${ }^{2}$

1. And, David Hajdu adds, even those who couldn't read, especially through the funny pages' "accessibility to nonreaders in the immigrant population" (12).

2. Histories of and historical approaches to comics are plentiful, and I won't bother in this essay to summarize them all, but seeing as I'm about to sketch a history of my own that builds on many of the insights from those previous works, I'll mention a few of the best histories of comics here for a reader interested in learning the bigger picture. For 
I want to locate three specific characteristics in this prehistory and trace them into the proper history of comics as a product for children. The first of these is format, by which I mean simply the size and shape of the pieces of paper that delivered comics to their readers.

Let's start with newspapers. If we're thinking about format, then the oversized, spread-out-on-the-living-room-floor sheets of paper on which newspaper comic strips were printed look quite different from the magazine-style periodicals that we think of today when someone uses the name "comic book." Considering the familiar image of middle-class children sprawled out on a living room floor reading the funny pages, it is tempting to assume that children's comics start here, in the same place modern adult comics began. It is certainly true, as Charles Hatfield has written, that young people of the late nineteenth and early twentieth century read newspaper comics "in droves," but, he rightly insists, "those comics were not made 'for' them or assigned to them in any exclusive sense" (170).

What Hatfield means is that newspapers were shared objects, and the comics within them were passed between or even read simultaneously by adults and children. That sharing was encouraged by the shape and size of the newspaper page. As a result, although certainly children did read comics in newspapers,

my money, the best history of US comics is Jean-Paul Gabilliet's Of Comics and Men: A Cultural History of American Comic Books, first published in 2005 and translated in 2010. I have also relied heavily on Paul Lopes' Demanding Respect: The Evolution of the American Comic Book. More specialized histories that have nonetheless been extremely important to me here and elsewhere in my work on comics have been Trina Robbins' From Girls to Grrrlz: A History of Women's Comics from Teens to Zines and Roger Sabin's Comics, Comix \& Graphic Novels: A History of Comic Art. Jan Baetens and Hugo Frey's The Graphic Novel: An Introduction provides an excellent history that was published too recently for me to use in this study. Also of note are pages 10-18 of Scott McCloud's Understanding Comics and Gérard Blanchard's Histoire de la bande dessinée, which is, alas, only available in French. 
we can't think of newspaper comics as precisely "children's comics." Hatfield talks about what he calls a "zone of ambiguity" that the comics section created in newspapers: children read the comics, but so did adults, and smart writers, illustrators, and editors remembered that mixed audience, that "ambiguous" audience, as Hatfield would have it, when they put the comics sections together (169). If we want to point at something and say with confidence that it's comics for children, then we can't point at newspapers, which were designed for and consumed by a mixed audience. And we can tell that they were designed for a mixed audience because of their format.

That format didn't last forever, and when it changed, the potential for comics that were specifically for children began to take shape. I've been arguing that we can't call newspaper comics of, for example, the late nineteenth century "children's comics" because the format anticipated a mixed audience. However, when comics began appearing as magazine-style commodities in the early twentieth century, that format changed dramatically. Newspapers are oversized and easily read by multiple people simultaneously, but magazines are not, and it feels uncomfortable for multiple readers to consume a magazine together (if you don't believe me, pay attention to your blood pressure the next time you're reading a magazine and someone tries to read over your shoulder). Because comic books were of a size and shape that invited solitary, private consumption, ${ }^{3}$ they, like other magazines, could target narrower reading audiences than newspapers. And if they could be, indeed if they were assumed to be, consumed privately, then they could target specific sections of the comicsreading audience. They could be, for the first time, for kids. 
However, before these new products in this new format could really be considered to be for children, they had to divest themselves of a characteristic left over from the newspaper days, a characteristic that, much like format, marked the early comics as for both children and adults. I'm talking here about content. Today, we think of comic books as the venue in which new tales are told on a monthly basis. Indeed, the thicker books that many people call "graphic novels" are often just reprints of materials that first appeared in the monthly comics, by which I mean the magazine-style comic books that collectors today affectionately call "floppies." Because graphic novels tend to be compilation reprints of comics that first appeared serially in the floppies, we tend today to think of comic books as sources of new material, but the content of the first floppies was anything but original. Instead, in a move that anticipated the majority of the graphic novel industry by more than half a century, publishers took material that had originally appeared in the newspapers and reprinted it on cheap paper, with the old strips now packaged in a magazine format and sold at newsstands alongside the newspapers where the comics themselves had first run. In fact, this is where the name "funny books" came from: the comics section of the newspaper was the funnies, and these new magazines were just books made from the funnies. If the material in the funny pages was for a mixed audience, then the material in the new funny books was, too. Therefore, although the shift from newspaper format to magazine format allowed for a private reading experience that could specifically target children, the content in that new format was still content that came from the mixedaudience $^{4}$ venue of newspapers.

4. My use of "mixed" here recalls all sorts of other ways that the audiences for comics were mixed, such as according to nationality, race, socio-economic class, and so on. There's not room in this chapter to explore that point, and I'm isolating age in order to 
We've talked about format and content as two of the characteristics that mark the early comics as for-or, more accurately, not solely for-children, but one characteristic remains: price. Up through the early 1930s, comic books were almost exclusively promotional items designed to draw customers-the adults and children who read newspaper comics-to support the sales of other products, much in the same way that comics in newspapers existed in order to help sell newspapers. As John Goldwater puts it, at this point, the medium was not exactly a target of consumer desire in its own right, "but was used as a premium by a number of firms to promote the sale of their products" (19). The purpose of the first comic books was to induce people to buy other products , as Jean-Paul Gabilliet has noted, at a Gulf service station or Woolworth's department store (8-9). Thus, when Harry I. Wildenberg and Maxwell C. Gaines developed premiums in the 32-page, stapled magazine format that would come to be associated with comic books, ${ }^{5}$ they were initially only expanding the reach of cross-written comics in an effort to draw shoppers of various ages into the sponsors' retail venues, not creating something inherently for children. In these early years, when comic books were giveaways, their function was cross-generational in the same way that newspaper comics were cross-generational.

However, when comic books became priced commodities, the sort of thing that could be called children's comics became much more likely, maybe even inevitable. In 1933, when Wildenberg and Gaines produced Famous Funnies as a free premium, the point of the book was to attract readers of various ages to buy other 
products. ${ }^{6}$ Its content (reprinted from newspapers) and price (free) indicate that its purpose was cross-generational. In 1934, however, when Famous Funnies was re-launched with a ten-cent price tag and "specifically intended to be sold" (Goldwater 19), the audience began to shift from a mixed audience induced to buy other products to a young audience who wanted to and, crucially, could buy the comic book as an end to itself. Walt Simonson, whose scripts and pencils would become mainstays of superhero comics, recalls that "There was a time when [comic books] were the first thing a kid could buy with his own money, that their parents had no control of," and it is that financial availability to children that is key to the history I am constructing (qtd. in Irving 79). The price was so low, in fact, that, according to Bradford W. Wright, it wasn't until the sixth issue that the relaunch of Famous Funnies earned more money than it cost to make. The first issue alone netted a loss of $\$ 4000$ (4). If Eastern Color, the publisher of Famous Funnies, hadn't shown significant patience with the experiment, it's very possible that comics would have reverted to and remained forever giveaway rather than commercial objects in their own right.

It's here, finally, that we can begin to see a separation between the comic strips that were for shared audiences and the comic books that were for children. Before, the format indicated an anticipated shared audience, and even when the format changed, the content in the new floppies still came from the shared newspapers. When the new floppies (with their mixed-audience content) were given away, their purpose was to draw both adults and children to buy another product. But once the comic book became something for sale, it became a product in search of a

6. The history I am telling here has been documented in many places, but perhaps the most compelling version, with far more details than I can include here, is in Hajdu's The Ten-Cent Plague, especially pages 19-22. 
specific market. That market did not have to be children, but it could be. This shift in price for comics sold in the new, more individual format is how the potential for an object that can be called "children's comics" came to be. Stephen Kline explains that comics publishers came to realize that although children wanted stories, they "did not have enough money to buy books on their own. Comics could be produced on cheap newsprint. At ten cents a comic, these new books were marketed so that children themselves could become the purchasers, using their allowance, savings or disposable earning" (100-1). To be sure, adults could also buy Famous Funnies, but the price suggested a product that was courting the dimes of children who had very little money to spend and who, presumably, also did not need to spend that money on necessities. The content of early for-sale comics magazines such as this one still drew heavily from newspapers, so the stories themselves were cross-written tales rather than tales for children. However, the format and cost of Famous Funnies in 1934 provided another step toward establishing children's comics. Within a year, Famous Funnies' sales were so strong that they all but guaranteed the future of magazines in that format and at that price point. ${ }^{78}$

7. See Ron Goulart's entry on Famous Funnies in The Encyclopedia of American Comics, which claims that by 1935 , "the new magazine was netting $\$ 30,000$ an issue" (125).

8. Gabilliet, however, records a comic in tabloid format that was for sale earlier than Famous Funnies. He points to George Delacorte's The Funnies, a book that debuted in 1929 but died an early death. Gabilliet, following Mike Benton, theorizes that it was the book's initial cover price (30 cents until issue 22) that doomed the venture. Delacorte eventually lowered the price to five cents, but Gabilliet proposes that the change came too late. The Funnies did run fifteen issues at the lowered price, perhaps indicating that it was sustainable at that selling price. If Gabilliet is right, and if Delacorte had launched his tabloid with the lower cost, perhaps the history of children's comics would have begun there. 


\section{Turning Points: Original Content and Themed Comics of the Mid-1930s}

The first issue of New Fun Comics, also published in 1934, is a watershed moment in the history of children's comics. Because "most of the first wave of comic books from 1934 to 1938 used reprinted comic strips" (Lopes 18), New Fun stands out-because of its atypical original content-from the other comics that immediately followed the relaunch of Famous Funnies. And with a ten-cent cover price, New Fun presented itself as a commodity ideal for children's budgets. Moreover, the pages of New Fun included the funny animal story "Pelion and Ossa," a strong indicator of what the future held for children's comics. New Fun was published in a tabloid format, so we shouldn't imagine it quite as the sort of comic book we can buy today. Today's format was popularized by Wildenberg and Gaines, and its sheets are smaller, more emphatically indicating a private audience. However, the tabloid format was smaller than that typically used in the funny pages of newspapers. Further, the cover of New Fun was made of card stock, firmer stuff than the paper covers of other comics magazines, which meant that although the pages were larger than we think of as ideal for private consumption, the covers could be gripped in a way that facilitated private reading. As a result, New Fun represents a fundamental shift from the cross-written, free, broadsheet comics to the comics written and priced for private consumption by children. Although the great flood of children's comics would not rush into the market until the end of the decade, New Fun demonstrates that publishers were attentive to children as consumers of comics by the mid-1930s. It had an adapted format, original content (including the funny animals that would later dominate children's comics), and a price that invited children 
as its audience'. If we need a single title to point to and claim as the first comic book really for children instead of an audience of children heavily mixed with adults, the first issue of New Fun is probably our best bet. ${ }^{10}$

\section{But New Fun was followed in short order by a sea of change in the comics industry that would massively alter the nature of the content in children's comics yet again. Detective Comics, whose}

9. The year 2000 saw an interesting reply to New Fun: Art Spiegelman and Françoise Mouly launched the Little Lit series, the first volume of which included a variety of short comics explicitly aimed at children, some of the entries reprints, some of them new. The book was published in an oversized hardcover and at a price point well outside the pocket change of children at the turn into the new century. Little Lit, then, is evidence of two things: the changing market strategy of children's comics in the age of graphic novels and the deep historical awareness of many contemporary comics creators.

10. Comics scholars have grown increasingly suspicious of defining comics in the mechanical ways that I use in this essay, especially because such techniques lead toward exactly what I have (reluctantly) offered in this paragraph: an argument for "firsts." On the one hand, I understand and even agree with such skepticism, having witnessed many times the endless scholarly circling around which item can really be said to be the "first" of anything. On the other hand, the point of this essay is precisely to provide a historical starting point for something called "children's comics," so, tedious or not, I'm afraid that I'll have to provide some guidelines for distinguishing between newspaper comics, children's comics, and other comics. For a recent and alternative approach to the idea of how to define comics in a way that sidesteps the problems of my argument, consider Bart Beaty's endorsement of a "comics world," a formulation that investigates a community of people around something that they call comics and allows their consensus to define comics rather than using a set of objective hallmarks. Beaty points to the professionals who produce the comics (37), the distribution network of the comics (42), and the formal and informal published conversation about comics (103) as cornerstones of the "comics world." As useful as Beaty's term is, though, I'm not convinced that it will provide much illumination on the early days of children's comics in which I am interested in this essay: although certainly a set of professional cartoonists existed at this time, the channels of distribution for children's comics was difficult to distinguish from the channels of distribution for newspapers at the time, and the published conversation about children's comics was limited and dispersed during the days when the genre took form. Therefore, like it or not, we're probably stuck for now with the necessity of recognizing children's comics using the more ham-fisted techniques I offer in this essay. 
first issue was cover-dated March 1937, has been widely hailed as the first themed comic (see for example Feiffer 5 and Lopes 19), a significant break from anthology comics, including comics such as New Fun and all of the other comics drawn from the funnypages model found in newspapers. Newspaper comics sections acted as a sort of compendium, including multiple genres and even more styles and storylines on every spread. ${ }^{11}$ When National, the publisher of Detective Comics, followed that title with Action Comics \#1 in 1938, the result was an explosion in comics' popularity that continued well into the 1950s (Lopes 2). If you recognize the name Action Comics today, that's almost certainly because it was in that floppy that National-today known as DC Comics-introduced Superman, followed a year later with the premier of Batman in Detective. The rest of the industry quickly learned from National's example. Not only did other publishers largely discard mixed-genre comics in favor of themed books, but they followed the lead of National and developed books focused on specific characters (Lopes 20). In less than half a decade, comics had transformed from giveaway premiums recycling a variety of newspaper strips to a thriving industry of cheap magazines presenting not just original content, but original content focused on individual themes and characters.

\section{The Early 1940s and the Ascendancy of Children's Comics}

The explosion of single-character titles was not precisely an event of children's comics, but of comics as a whole. Nonetheless, the new focus of comics set the stage for what must be regarded as the beginning of the high point of children's comics. Although 
comics of the previous half-decade had certainly attracted young readers all along, "the age range" of comics, as Roger Sabin puts it, "took a marked tumble with the rise of the funny animal genre in the 1940s" (35). That rise began in 1940 with Dell Publishing's extraordinary success selling themed comics about funny animals, especially the first major work in the genre of children's comics, Walt Disney's Comics and Stories. Its first issues reprinted colored, reformatted strips, but by 1942 the book featured original content. The book was a massive success, and from 1940 to 1953, similar titles proliferated, offering a host of Looney Tunes characters to complement Mickey Mouse, Donald Duck, and friends (Lopes 21-2, Sabin 36). Again, the industry's turn from the anthology model borrowed from the funny pages to the themed and singlecharacter model was not exactly an event of children's comics. However, when comics shifted from anthologies to more focused titles, the groundwork for funny animal comics was laid. As funny animal comics expanded to dominate the industry, the submarket of children's comics became the main market. It is here that the idea of comics as for children, an idea that for decades became a truism, took hold.

For roughly 20 years, funny animals dominated comics. Walt Disney's Comics and Stories, for example, rose from an initial monthly circulation of 252,000 to over a million in 1942, two million in 1947, and three million in 1953 (Andrae 6). Children were not the only readers of funny animal comics, and considering the extraordinary quality of art and writing in the books-think of Carl Barks' legendary work on Disney's duck family, Floyd Gottfredson's work with Mickey Mouse, and Walt Kelly's work for both Disney and Looney Tunes before going on to develop the classic strip Pogo-naturally readers of any age would have sought them out. Still, children were the industry's most successfully targeted readers. Led by the massive success of funny animal 
comics, the comics industry as a whole began to lean toward younger readers in a way that it never had before. Norbert Muhlen's 1949 study of the effects of comics on children claimed that

Between six and eleven years of age, 95 per cent of the boys and 91 per cent of the girls throughout the nation, with few regional differences, read an average of 15 comic books per month. In the age group between twelve and eighteen, more than 8 out of 10 children still read at least a dozen every month, with the boys again slightly leading the girls. (81-2)

The industry's quick change from anthology comics to comics organized around a single theme or character made possible the boom in funny animal comics, with the result that 1940 marked the beginning of a period of American comics history dominated by children's comics.

Funny animal comics were perhaps the most visible of the new dominance of children's comics, but others also cut a wide swath in the 1940s. For example, when Gabilliet writes that "humorous comic books for young children were among the true innovations of the 1940s" (24), it is tempting to assume that he means only funny animal comics, but humor helped sell comics well outside the typical venues. Gabilliet even includes Captain Marvel as a "deliberately humorous" superhero (25), and since the Big Red Cheese, as he came to be known, first appeared in a comic book cover dated February 1940, well before the fall debut of Walt Disney's Comics and Stories, Captain Marvel represents a link between the themed superhero comics of the late 1930s and the funny animal comics of the early 1940s. More overlap between funny animal comics and Captain Marvel became evident 
with the 1947 debut of Cap's friend Mister Tawky Tawny, the well-mannered, well-heeled, talking tiger. Paul Lopes has noted the launch of more funny animal books during the 1940s-Funny Frolics in 1945 and Animal Antics in 1946-as well as humorous comics featuring child characters-famously including Lulu (who first appeared in strips in the 1930s and became the star of the comic book Marge's Little Lulu in the late 1940s) and Casper (who first appeared in animation and made his way to comic books in 1949) (23). Humor in many forms was a booming business in children's comics, and since children's comics dominated the market, humor dominated the market.

You may have noticed, though, something about Muhlen's 1949 study of the consumption of comics that looks startling in the light of how comics have recently been perceived. One important difference between comics for children at the end of the century and those of the mid-twentieth century is that although adults in, say, 1990 tended to assume that comics appealed more to boys than to girls, girls were major consumers of comics in the 1940s, as Muhlen's statistics testify. In 1941, the organization behind Parents magazine began publishing Calling All Girls, with comics features running alongside prose. Sabin describes the magazine as "centred around 'morally proper' role models, such as nurses and historical heroines, with articles on etiquette and 'back to school fashions,' and comments from 'Advisory Editors' such as Shirley Temple" (89). Sabin also notes other part-comics, partprose magazines for girls including Polly Pigtails and Sweet Sixteen, the latter of which boasted "Comics and Stories for Girls" as a subtitle. Both were published by the Parents Magazine Press beginning in 1946. Lopes reports that "The publisher boasted a combined circulation of 750,000 copies in 1942" (25-6). Although Parents had stopped publishing comics by the middle of 1950 (26), these and other comics for girls remain evidence that girls were 
a vital component of mid-century comics readership. For many contemporary comics aficionados, comics are a boy's medium, but the origin story of children's comics demonstrates that there is nothing inherently pro-boy or anti-girl in the medium of comics. Examining how and why comics abandoned girls is a task that requires space far beyond what I have here, but a history of the emergence of children's comics is duty-bound to point out that from the very beginning, girls were reading comics right alongside boys.

The success of comics for children also led to some launches that had little to do with gendered focus...or humor. Lopes notes, for example, the religious series Topix Comics, first released in 1942 and remaining in print until 1972, long after most comics marketed to children had disappeared (26). Gabilliet, to take another example, points to the True Comics series, again by the same publisher as Parents magazine, launched in early 1941 and containing "biographies of Winston Churchill and Simon Bolivar and pages on malaria and the marathon" (26). Also under way in 1941 was Classic Comics, today better known by the name it adopted in 1947, Classics Illustrated. Gabilliet explains that the publisher, Albert Lewis Kanter, "was dismayed by his own children's interest in comic books and dislike of books without pictures. He thought that children would want to read the classics if they were first treated to comic book versions of the same stories" (27). "Classic Comics," writes Lopes, "had sold one million copies of its twenty-eight titles by 1946" (25). Gabilliet takes what is perhaps a common position in arguing that this sort of educational comic book, though it might have been an "immediate commercial success," owed its success not to children, but to the parents buying the books on behalf of the children (27). "Classic Comics," he opines, "became a long-lived best seller because it seemed to perfectly respond to the expectations of educators and, 
above all, proved an inestimable means for children to write book reports without reading the original works" (28). Evidence for this position is probably impossible to locate, and although I disagree with his opinion-adults routinely underestimate children's interest in nonfiction and challenging literature-I'm not sure that our disagreement matters. If one can consider as "for children" materials including picture books, nonprofit television programming, and other media designed by adults for children to absorb in ways that flatter adults' priorities, then didactic comics such as these must also be considered as for children. ${ }^{12}$

\section{Conclusion}

The story I have been telling in this essay has been how children's comics split from comic strips for a mixed audience in the 1930s and burst in several artistic directions in the 1940s, but my disagreement with Gabilliet points to some of the larger issues implicit in a debate about the emergence of an art form explicitly for children. Indeed, my chronological approach to this story obscures one of the most interesting issues accompanying the birth of children's comics: the debate over who would control what those comics meant and what role they played in maintaining a status quo in which adults were deeply invested. I opened my study by pointing to the shared audience anticipated by newspaper comics, but another comics specialist made that point in the 1950s: Fredric Wertham, whose best-selling (and, as Carol Tilley has demonstrated, deceptively argued) Seduction of the Innocent touched off a controversy over comics, said exactly the same thing in the 1954 book that made him famous. For Wertham, though, the point was not how comics were read, but 
what authority oversaw them. "When comic strips are reprinted as comic books," Wertham warned, "the censorship that existed before, when they were intended for adults, disappears and the publisher enjoys complete license. He can (and sometimes does) add a semipornographic story for the children, for example, and a gory cover-things from which censorship protects the adult comic strip reader" (14-5). Wertham takes for granted the adult readership that I postulated, but whereas for me that readership makes a historical point, for Wertham, the point is that adults-in this case, censors-prevent comic strips from offending adult standards, but other adults-in this case, publishers of comic books-produce subversive materials by sidestepping conventional authority. At stake in the separation of mixed-audience comic strips and comic books marketed for children is not just a historical argument about where children's comics start, but a debate about who gets to control the cultural impact of the content in comics.

Adults were the ones best positioned to control comics and their meanings, but adults were never completely transparent about their goals, and the extent to which they were successful is similarly doubtful. When Ian Gordon first encountered the quotation from Wertham that I just highlighted, his reaction was one of puzzlement. "This comment struck me as odd," he recalls, "because a number of comic strips, such as Chester Gould's Dick Tracy, seemed just as violent as the fare offered in comic books" (3). Gordon is of course right: the distinction between the content of the two is not so much that one was sparkling pure and the other sensationalist, but that comic strips, because of their censors as much as their anticipated audience of adults reading alongside children, carried the impression of having been vetted by adult society in a way that comic books did not. To that end, Gordon demonstrates, comic book publishers of the early 1940s 
repositioned themselves in the public eye so that their wares appeared to require no external oversight. Squeaky-clean characters such as Superman, for example, "sold more than ray guns; in the early 1940s he sold the virtues of comic books themselves" (135). But while many publishers were doing their best to provide fare that pleased parents, writers also encoded within comic books a sense that children could push back at adult authority. Martin Barker's reading of early children's comics is that comics presented a sober view of the prevalence of adult power, but also offered "an exercise in children's handling of" that power (86). Barker stops short of saying that such comics provided any kind of genuine subversion, but he argues that children's comics spoke frankly to children about under whose power they would find themselves outside of the pages of comics, but within those pages, "a child can 'play' at challenging adult authority in a way that acknowledges that s/he cannot defeat it" (276). Even as comics were separating from adult authority, they were both acknowledging and, sometimes, poking at that authority.

Comics were, I have been arguing, originally for children and adults together, and it was only through the slow drift of format, content, and price, that a sort of comic book specifically for children emerged at all. In the early days, children and adults fought over whose turn it was to read the funny pages. As comics for children developed into their own genre, the fight was increasingly over who would control what comics meant.

\section{Works Cited}

Andrae, Thomas. Carl Barks and the Disney Comic Book: Unmasking the Myth of Modernity. Jackson: UP of Mississippi, 2006. 
Baetens, Jan and Hugo Frey. The Graphic Novel: An Introduction. Cambridge: Cambridge UP, 2015.

Barker, Martin. Comics: Ideology, Power and the Critics. Manchester, UK: Manchester UP, 1989.

Beaty, Bart. Comics versus Art. Toronto: U of Toronto P, 2012.

Blanchard, Gérard. Histoire de la bande dessinée. 1969. Verviers, Belgium: Marabout Université, 1974.

Feiffer, Jules. The Great Comic Book Heroes. 1965. Seattle, WA: Fantagraphics Books. 2003.

Gabilliet, Jean-Paul. Of Comics and Men: A Cultural History of American Comic Books. Trans. Bart Beaty and Nick Nguyen. 2005. Jackson: UP of Mississippi, 2010.

Goldwater, John L. Americana in Four Colors: A Decade of Self Regulation by the Comics Magazine Industry. NY: Comics Magazine Association, 1964.

Gordon, Ian. Comic Strips and Consumer Culture: 1890-1945. Washington, D.C.: Smithsonian Institution Press, 1998.

Goulart, Ron. "Famous Funnies." The Encyclopedia of American Comics. 1990.

Hajdu, David. The Ten-Cent Plague: The Great Comic Book Scare and How It Changed America. New York: Farrar, Straus, and Giroux, 2008.

Harvey, R.C. "John Goldwater, the Comics Code Authority, and Archie." The Comics fournal. 28 July 2011. Web. Accessed 17 November 2013.

Hatfield, Charles. "Redrawing the Comic-Strip Child: Charles M. Schulz's Peanuts as Cross-Writing." The Oxford Handbook of Children's Literature. Ed. Julia L. Mickenberg and Lynne Vallone. New York: Oxford UP, 2011: 167-87. http://dx.doi.org/ 10.1093/oxfordhb/9780195379785.013.0009

Irving, Christopher. Leaping Tall Buildings: The Origins of American Comics. Brooklyn: PowerHouse Books, 2012. 
Kline, Stephen. Out of the Garden: Toys, TV, and Children's Culture in the Age of Marketing. London: Verso, 1993.

Lopes, Paul. Demanding Respect: The Evolution of the American Comic Book. Philadelphia: Temple UP, 2009.

McCloud, Scott. Understanding Comics: The Invisible Art. Northampton, ME: Kitchen Sink Press, 1993.

Muhlen, Norbert. "Comic Books and Other Horrors: Prep School for Totalitarian Society?" Commentary January 1949: 80-87.

Robbins, Trina. From Girls to Grrlz: A History of Women's Comics from Teens to Zines. San Francisco: Chronicle Books, 1999.

Sabin, Roger. Comics, Comix \& Graphic Novels: A History of Comic Art. London: Phaidon Press Ltd, 1996.

Sanders, Joe Sutliff. "Chaperoning Words: Meaning-Making in Comics and Picture Books.” Children's Literature 41 (2013): 57-90. http://dx.doi.org/10.1353/chl.2013.0012

Tilley, Carol. "Seducing the Innocent: Fredric Wertham and the Falsifications that Helped Condemn Comics." Information \& Culture: A fournal of History 47.4 (2012): 383-413.

Wertham, Fredric. Seduction of the Innocent. New York: Rinehart \& Co. 1954.

Wright, Bradford W. Comic Book Nation: The Transformation of Youth Culture in America. Baltimore: The Johns Hopkins UP, 2001. 


\title{
2. "Let's Go \\ Exploring!"
}

\section{ILLUSTRATING CHILDHOOD DEVELOPMENT IN CALVIN AND HOBBES}

\author{
James Curtis
}

\section{Introduction}

Bill Watterson's Calvin and Hobbes is undoubtedly one of the most well-known American comic strips. While Watterson's early years as a cartoonist would bring him much disappointment and rejection, he found his niche when "eventually, one syndicate expressed some interest in [his] work. They didn't like the strip [he] had done, but they liked one of the secondary characters-a boy with an imaginary stuffed tiger" (Watterson 9). By developing the personalities and creating the highly imaginative and extraordinarily humorous situations of this six-year-old boy and his stuffed tiger, Watterson would finally find success in the art that he had pursued since childhood. During its ten-year lifespan, 
Calvin and Hobbes was syndicated in over 2,400 newspapers around the world, and sales of the series' compiled book collections number in the tens of millions. Even now, twenty years after the comic's final strip appeared, Calvin and Hobbes continues to be reprinted in various newspapers world-wide. Moreover, there is little doubt that Watterson's creation was highly influential during its time; in fact, Pulitzer Prize-winning cartoonist Berkley Breathed famously drew one of his own characters sporting a "Calvin and Hobbes Rule!" t-shirt.

Watterson's Calvin and Hobbes depicts the various adventures, mischievous deeds, and flights of imagination of elementary-aged Calvin and his stuffed tiger, Hobbes, who-in Calvin's mind-is actually a living creature. One of the elements that makes the comic so interesting is that its readership is as broad as some of the complex issues that the characters address. ${ }^{1}$ During the span of its decade-long run, Calvin and Hobbes was enjoyed by readers young and old, male and female, rich and poor alike. Perhaps the reason for this diversity in readership is because Calvin and Hobbes touches on the imaginative potential of our own childhoods and how we ourselves might have used "attachment objects" (like Hobbes) to explore and to make sense of the world around us.

In terms of childhood development, Calvin is experiencing what D.W. Winnicott and other early child psychologists refer to as a "transitional phase," where children use "transitional objects" (like the proverbial "security blanket") to aid in negotiating their own place in the world at large. Winnicott was one of the first to draw attention to the importance of this developmental period. According to Winnicott, a child's ability to transfer some of its

1. "Reruns of the strip, no longer available to newspapers in North America, still appear in more than 50 countries around the world (Miss Wormwood sends Calvin to the corner in Chinese, Vietnamese, and Arabic" (Campanelli, n.p.). 
egocentric (or self-centered), libidinal energy onto an external object is a healthy, progressive step towards the beginning stages of socialization. In other words, although many parents-even in our own contemporary culture-manifest certain anxieties over their children becoming overtly attached to "comfort objects," Winnicott and others of his school of theory demonstrated quantifiably that this phase in a child's life is not only psychologically healthy but is, in fact, crucial to normal psychological progression from childhood to adulthood.

Of course, one of the many things that Calvin and Hobbes does is to explore the various nuances of the "transitional phase" of childhood. From Calvin's interactions with his parents, his friends, his teacher, and of course, Hobbes-his "transitional object"-Watterson illustrates just how children use transition objects to begin to negotiate their own place in the world around them. Employing a framework of developmental psychology supplied by Winnicott and others, this analysis aims to highlight the ways that Watterson's Calvin and Hobbes explores the many facets of the "transitional phase" and how Calvin's interactions with others (as well as his many moments of deep self-reflection and philosophical musing) reminds us just how psychologically beneficial "transitional objects" like Hobbes are. The purpose of this kind of analysis is to provide us with a renewed sense of the imaginative potential of childhood that serves, in part, to explain the universal appeal and popularity of this highly successful comic strip. 


\section{D.W. Winnicott and the "transitional phase": A brief overview}

Even to those who may be unaware of the history of psychology and psychoanalysis, the name Sigmund Freud is familiar. This notoriety exists, of course, because Freud's theories on dream interpretation, the structure of the human psyche, and psychological pathologies have been disseminated more widely than any other psychological ideology throughout the history of the discipline. Simply put, modern psychoanalysis as we know it would not exist without Freud. However, what some may not be aware of is the role that his daughter Anna played in shaping the conception of early childhood psychology and the analysis of child development. Indeed, Anna Freud was instrumental in the early days of child developmental psychology, taking many of her father's theories and applying them to the psychological progression of children towards adulthood. ${ }^{2}$

Another important early thinker in the first days of child psychology was Melanie Klein, whose focus on the infant's attachment to certain "objects"-specifically the infant's primal tendency to objectify the mother as first and foremost a source of nourishment and security-caused her eventually to split from other early childhood developmental psychologists like Anna Freud and to form her own "object relations" school of child psychology. In Klein's view, this primary relationship of the child to the mother forms the foundation of the child's entire psychological makeup, and his or her capacity to develop normally from childhood to adulthood will depend upon where the child shifts its focus after beginning to recognize him- or herself as a separate entity from the mother. ${ }^{3}$ 
One of the more important members of Klein's "objectrelations" school of developmental psychology was D.W. Winnicott, who-ironically-often cites Freud more than Klein in his own theoretical concepts. Indeed, the most significant contribution that Winnicott made to the burgeoning field of child developmental psychology was the notion of the "transitional object" and the "transitional phase." In his 1951 essay "Transitional Objects and Transitional Phenomena," Winnicott-no doubt drawing on earlier attachment theorists like Richard Bowlby-was the first to introduce the concept of the "transitional object" and to discuss the ways that the child uses such objects not only to begin the essential separation from the mother figure, but also to negotiate his or her own social, emotional, and mental space in his or her gradual progression towards independence and selfidentity. For Winnicott, there was a hitherto ignored yet vitally essential

...part of the life of a human being, a part that we cannot ignore, an intermediate area of experiencing, to which inner reality and external life both contribute. It is an area which cannot be challenged, because no claim is made on its behalf except that it shall exist as a restingplace for the individual engaged in the perpetual human task of keeping inner and outer reality separate yet interrelated. (230)

Arguably, nowhere in the history of American comics is the child's capacity to keep his or her inner and outer reality "separate yet interrelated" more apparent (or more well-illustrated in both a symbolic and literal sense) than in Bill Watterson's Calvin and 
Hobbes. By using Winnicott's theories as a critical framework for understanding the content of Watterson's work, we can begin to understand-at least in one respect-why Calvin and Hobbes was such a vastly successful comic during its ten-year run and why it remains both popular and relevant to this day.

\section{Hobbes and other transitional objects}

While the notion of the "transitional object" is most commonly conflated with the child's "security blanket"-and with good reason, since the two can be one and the same-Winnicott's notion of this item goes far beyond offering the child a sense of security after his or her initial sense of increasing independence. In fact, in terms of childhood psychological development, one of the more vital functions of the transitional object is that it allows for the child to negotiate the space between fantasy and reality. Winnicott makes it clear that this relationship is not meant to be symbolic: "when symbolism is employed the [child] is already clearly distinguishing between fantasy and fact, between inner objects and external objects, between primary creativity and perception" (Abram 344). In other words, for the child who is undergoing the transitional phase, the transitional object itself is just as real as everything else in the child's life. There is no difference between fantasy and reality, as the child has yet to progress fully through the transitional phase-the resolution of which, according to Winnicott's ideas, allows for the child's clear distinction between fantasy and reality.

From the very first Calvin and Hobbes strip, Hobbes serves as Calvin's primary transitional object. When Calvin tells his father, "So long, Pop! I'm off to check my tiger trap!" (22), we do not expect to see that Calvin has trapped an actual tiger. However, this is exactly the way that Watterson represents the experience 
for Calvin, who believes that he has indeed captured a real tiger. From this very first strip in the series, the comic itself gives us evidence-in three separate strip sequences-that indicate that Calvin does not distinguish between fantasy and reality. The first is when Calvin checks his tiger-trap and finds Hobbes eating a tuna-fish sandwich that Calvin had used to bait the trap. Calvin then approaches his father and asks, "So dad, what do I do when I catch a tiger?" (22). Calvin's father gives him the usual parental brush-off, and Calvin goes inside to feed his newly-caught tiger. The illustration that the strip then gives us of Calvin physically giving food to Hobbes and having Hobbes respond in turn reminds us of the reality of Calvin's relationship with Hobbes, at least in terms of Calvin's developing childhood psyche. The final-and most compelling-illustration of Hobbes as transitional object in this first strip comes during the final few panels, when Calvin's dad bursts into his bedroom, exclaiming, "What's all this noise? You're supposed to be asleep!" (22). Calvin responds with: "It was Hobbes, Dad! He was jumping on the bed! Honest!" (22). It is important to note that while Calvin's father is in the room, Hobbes appears as nothing more than a stuffed animal; however, immediately after the adult leaves the room, the next panel shows Calvin and Hobbes arguing with one another, and we see Hobbes once again as a living creature. Again, from the very outset of Watterson's Calvin and Hobbes, we are given explicit illustrations of Winnicott's theories insofar as Calvin is experiencing them. Calvin's blurring of the boundaries between fantasy and reality shows us that he is in the midst of the childhood "transitional phase." Furthermore, the comic's ambivalent (and never definitive) depiction of Hobbes as both a living creature and a stuffed animal show us that Hobbes is the "transitional object" through which Calvin is negotiating this essential childhood psychodevelopmental stage. 
Of course, Hobbes is not the only transitional object that Calvin utilizes throughout the series, and the effacement between imagination and reality is hardly limited to the first strip in the Calvin and Hobbes oeuvre. In fact, the imaginative aspect of the comic is probably the most central recurring theme throughout the entire series. Perhaps the richest (and most popular) illustration of this interplay of reality and imagination through use of a transitional object can be found in one of the comic's most recurrent of Calvin's alter-egos: "Spaceman Spiff." The first time that this infamous persona of Calvin's appears is in the November 29th, 1985 strip. In terms of Calvin's relationship to transitional objects and his use of them to create imaginative scenarios through which he makes sense of the world around him, two facts are essential. First, Calvin's "Spaceman Spiff" persona almost always appears at school (where Hobbes-his primary transitional object-is not present). And second, in the absence of Hobbes, Calvin (as "Spaceman Spiff") will always find some tangible object through which he can negotiate his often precarious situations, albeit through some sort of fantastic escapism. In the initial appearance of "Spaceman Spiff," the strip begins with Mrs. Wormwood-Calvin's teacher-chastising Calvin: "We'll see what the principal has to say about your attention span, young man!" (26). Immediately, Calvin assumes his "Spaceman Spiff" persona, and while the reader knows that, in reality, the protagonist is being marched to the principal's office by his teacher, the next panel shows "Spaceman Spiff" being led by a giant alien wielding a spear. Calvin's fantasy vision is captioned with the following exposition box: "The valiant Spaceman Spiff has been captured! The aliens doubtlessly want the secret formula to the atomic napalm neutralizer! Moments from the torture chamber, Spiff springs into action!" (26). The next panel returns the reader to reality, where a very perplexed Mrs. Wormwood 
and Mr. Spittle (the school principal) are watching a determined Calvin munching a piece of paper as Mr. Spittle asks, "Why is he eating his hall pass?" (26). Here, in this first appearance of "Spaceman Spiff," Calvin gives the reader definitive evidence that, despite being in the absence of Hobbes-his primary transitional object-Calvin is still very much in the mindset of the transitional phase, as he concurrently utilizes both his imagination and a tactile object to negotiate his position when he gets into trouble at school. While the humor in this scene is apparent, the illustration of the child-in-transition is stark.

Another instance of Calvin's use of transitional objects and alter-egos can be seen in yet another recurring character in the series-"Stupendous Man." Making its debut in the strip that appeared on October 30th, 1987, Calvin often uses his "Stupendous Man" alter-ego to escape the confines of authority and his role as an imaginary superhero to negotiate issues of power dynamics. The way that this plays into his use of transitional objects is that when Calvin appears in his "Stupendous Man" form, he is seen donning a red mask and cape that was made for him by his mother. Winnicott, like most of his other object-relations cohort, places primary emphasis on the child's early attachment to the mother, especially when he asserts that the child's development "depends on the actual mother and her ability to meet the absolute dependence of the actual infant at the beginning, at the stage before the infant has separated out the mother from the self" (56-7). In fact, one could argue that without this emphasis on the initial relationship between the child and the mother-which is, simply put, an objectification of the mother as food-source on the part of the id-driven (or self-centered, primal need-seeking) infant-there would be no "object-relations" school of childhood development in the first place. This theoretical notion makes Calvin's use of the red mask and cape which his mother made 
him-which is itself a literal maternal cloak behind which he can hide-an effective vehicle through which the young boy can use his imagination to negotiate his own place in the world.

Fittingly, Calvin goes on to begin this sort of psycho-social negotiation in various comical ways in each of the "Stupendous Man" installments of the series through his encounters with his "arch-enemies": "Crab Teacher" (Miss Wormwood, Calvin's teacher), "Mom-Lady" (Calvin's mother), "Baby Sitter Girl" (Rosalyn, Calvin's babysitter), and "Annoying Girl” (Susie Derkins, Calvin's neighbor). In one particularly hilarious strip, Calvin tries to get out of going to bed by donning his "Stupendous Man" costume. Calvin narrates, "A crimson bolt blasts across the night sky, striking fear into the hearts of all evildoers! Yes, it's Stupendous Man, champion of liberty, defender of free will!” (167). He goes on to exclaim, "Some diabolical fiend threatens to establish a totalitarian system of rule! Only Stupendous Man can save the day! Aha! Just as I suspected! My evil arch-nemesis, MomLady!" (167). Calvin's mother then appears and asks, "Didn't I tell you to go to bed?!?" and we see Calvin (still wearing his costume) being carried upstairs as he cries out, "Oh, no! Stupendous Man's stupendous powers are no match against his adversary! Stupendous Man is vanquished!” (167). Though the preceding examples are only a few of the dozens of appearances of Calvin's alter-egos, his attempts at subversion of authority through fantasy and the use of the transitional object in the various appearances of "Spaceman Spiff" and "Stupendous Man" remind the reader that such objects are not the stuff of infantile attachment; rather, these objects can be (and often are, in Calvin's case) used to express the child's creativity and intelligence. 


\section{Transitional phenomena and the importance of play}

As Winnicott asserts, the transitional object is instrumental in the healthy psychological development of the child during his or her transitional phase; however, in order to fully appreciate the role that the transitional object plays, one must also understand that the psychological development of the child during the transitional phase relies just as heavily on how the child uses the object. For developmental psychologists, children's attempts to use their imaginations as means to make sense of the world around them revolve around the notion of play. For most people, "play" simply means a physical or imaginative game for children, something they carry out either by themselves or with others. However, for child psychologists, play is not merely a set of meaningless games that children engage in for no other reason than to occupy themselves. In fact, play (as a psychological term) involves an assessment of how these seemingly insignificant games that children engage in actually help them to negotiate the space between reality and imagination and how play allows children the opportunity to form vital social connections that will ultimately prove essential to their ability to function as members of their own society and culture.

Following the child's initial discovery and use of transitional objects, the implementation of those objects in the process of play is the next stage in psycho-development for children. Winnicott reinforces this idea when he asserts that "in health there is an evolution from the transitional phenomenon, and the use of objects, to the whole play capacity of the child. It is very easy to see that playing is of vital importance to all children, and that playing is a sign of health in emotional development" (171). 
Furthermore, he claims that play is not only "vital" to the child in the transitional phase, but that it does, in fact, serve the multifaceted purpose of allowing the child the opportunity to "master anxiety, to gain experience, to make social contacts, to integrate facets of personality, and to communicate with people" (150-52). In Watterson's Calvin and Hobbes, we see many examples of Calvin engaging in the process of play, and, perhaps more importantly, we see the capacity of play as a vehicle through which Calvin will continue to develop psychologically and to learn vital social lessons that will no doubt be important later in life. One series of strips in Calvin and Hobbes involves Calvin's creation of a group of "duplicates" using a cardboard box that the character imaginatively turns into a "duplicator." This sequence of strips perfectly illustrates Calvin's transition from the use of objects for personal exploration to the capacity for "whole play" that Winnicott discusses. For example, after six "duplicates" are created, we see each duplicate express its own individual desire; one says, "I'm going outside!" Another says, "I wonder what's on t.v. now?", while yet another says, "I don't know about the rest of you, but I'm going to get some cookies!" (12). After Calvin expresses his worries about his mother seeing all of the duplicates at the same time-which the duplicates promptly dismiss or ignore-he quickly follows with this observation: "What a bunch of devious little stinkers! Where'd they learn to misbehave like that?!" (12) Of course, the underlying humor in Calvin's statement is that Calvin knows (albeit subconsciously) that the "duplicates" are facets of his own personality and, therefore, have learned their "misbehavior" from Calvin himself.

In terms of child development, the payoff for the child character in this particular exercise of play comes when-after a series of social mishaps involving Calvin's parents, teacher, principal, and neighbor Susie Derkins-he "transmogrifies" his 
duplicates into worms, thereby ridding himself of them forever. By subconsciously recognizing how each duplicate embodies a different part of him, Calvin eliminates the need to divide himself (and his personality) into fractured facets, thus allowing him to reabsorb those various facets by using his imagination. In relation to Winnicott's ideas, this fantastic termination of Calvin's duplicates points to the child's ability to "integrate facets of personality"-facets which each of Calvin's duplicates no doubt embodied-during the development of the "whole play capacity" of the child.

\section{The transitional phase and}

\section{the relational experience}

The ultimate goal of Winnicott's notion of the transitional phase of childhood is the successful transition of the youngster from a self-centered individual who is content only with satisfying his or her own needs to a person who is capable of thinking of and forming healthy social connections with others. In fact, Winnicott specifically asserts that "the [child] does not start off as a person able to identify with other people. There has to be a gradual building up of the self as a whole or a unit, and there has to be a gradual development of the capacity to feel that the world outside and also the world within are related things" (181). It is only natural, then, that many of the most memorable moments in Calvin and Hobbes come from Calvin's attempts to negotiate social relationships outside of his immediate family, especially during his interactions with his teacher Miss Wormwood, his babysitter Rosalyn, and-in particular-with his neighbor Susie Derkins.

In one of the longer-running sequences of 1993, Calvin and Hobbes hold a meeting of the GROSS (Get Rid Of Slimy girlS) 
club in Calvin's tree-house and devise a plot to trick Susie Derkins into getting pelted with water balloons behind Calvin's house. In this sequence, Calvin tells Hobbes that he intends to pretend to drop a fake "secret letter" to Hobbes that will inevitably lead Susie to a spot behind the young protagonist's house, where he and Hobbes will be waiting to unleash a horde of water balloons on her. Despite Calvin's hardest (and very vocal) efforts to get Susie to see that he has "dropped" the secret letter, Susie at first takes no notice of him and, when she finally does notice the letter, she returns it to the boy-much to his extreme annoyance. Calvin attempts once more to pretend to drop his "secret letter" to Hobbes in front of Susie, but this time she has clearly caught on to his plan. After reading the letter, she yells (with sarcasm and intent that is obvious to the reader): "Gosh, it's almost noon! I'd better hurry over to Calvin's house if I want to spoil his plans!” (109). Calvin, falling for Susie's feigned ignorance, hurries to the spot where he thinks Susie will end up. Unfortunately for Calvin, Susie is already there, lying in wait with a water hose. The next few panels show a dripping wet (and obviously dejected and angry) Calvin, and in the next strip Calvin proclaims, "It's a dark day for the Get Rid of Slimy Girls Club. Our great plan backfired and I'm the one who got soaked! Oh, the shame! The ignominy!” (111). Although the humor in this scene is more than entertaining and certainly speaks to Watterson's ability to maintain the interest of the reader over an entire sequence of strips, it also illustrates his ability to capture certain crucial child psychological processes. By using Hobbes-a figment of his imagination-to formulate and to assist in enacting this ultimately failed plan to humiliate Susie Derkins, Calvin undoubtedly demonstrates Winnicott's ideas about the child in transition, as Calvin's attempt to enlist an imaginary figure from his internal world becomes a water-logged failure when it meets the reality of the external world and gives us a 
very visceral demonstration of the child's burgeoning "capacity to feel that the world outside and also the world within are related things" (181).

Of course, in terms of childhood development, the purpose of using play as a means of negotiating the relationship between the inner world of the child's imagination and the external world of the child's reality is ultimately to allow the child to be able to function within society. The most important transition in this process is the move from egotism to altruism, or the progression from self-centeredness to the capacity to feel sympathy for others. Though many (if not most) of Calvin's adventures and interactions with others involve the fulfillment of his own desires, there are also several instances throughout the series in which Calvin demonstrates that he is indeed beginning to make this important transition from egotism to altruism. In fact, one of the more popular sequences of strips involves Calvin's discovery of a seriously injured baby raccoon. In this sequence, Hobbes and Calvin are outside playing as usual when they happen upon a wounded animal. Calvin says, "Hobbes look! There's a little raccoon on the ground...but he's hurt. See, he's hardly breathing...you wait here and guard him I'll run and get mom" (242). Calvin runs to get his mother, who asks him to fetch a shoe box and a towel-which he quickly does. The next series of panels shows Calvin and Hobbes gathered around the shoe box, and Watterson's use of the lines on Calvin's face register his concern and anxiety about the health of the raccoon. That night, we see Calvin and Hobbes lying awake in bed. Hobbes says, "I can't sleep," and Calvin responds, "Me neither. I keep thinking about the raccoon. I hope he lives" (243). Sadly, we soon discover when Calvin anxiously races down the stairs to his parents the next morning that the baby raccoon died the night before. The next few panels show Calvin weeping unreservedly while his father tries to 
comfort him. Although this particular sequence of strips is one of the saddest in the entire Calvin and Hobbes oeuvre, it is also one of the most important in terms of Calvin's development.

Through his experiences with the raccoon and the animal's subsequent passing-Calvin begins to learn about life and death. In fact, the next strip in the sequence (following the death of the baby raccoon) finds Calvin musing aloud to Hobbes about his experience: "This is where dad buried the little raccoon. I didn't even know he existed a few days ago and now he's gone forever. It's like I found him for no reason. I had to say goodbye as soon as I said hello. Still...in a sad, awful, terrible way, I'm happy I met him" (244). The next two strips in the sequence continue with Calvin struggling to figure out why the baby raccoon had to die and ultimately accepting death as a part of life: "Mom says death is as natural as birth, and it's all part of the life cycle. She says we don't really understand it, but there are many things we don't understand, and we just have to do the best we can with the knowledge we have. I guess that makes sense" (244). Calvin's encounter with the baby raccoon show us two important facets to Calvin's burgeoning psychological development: first, he is beginning to move from a position of self-centered egotism to one of caring altruism; and second, he is beginning to actively think in terms of his own reality and specifically about the cycle of life and death. In terms of Winnicott's theories, this sequence clearly shows us that Calvin is indeed moving progressively along his "transitional phase" into a gradually more mature psychological state that allows him to successfully negotiate the realities of the outside world-a negotiation which, according to Winnicott, is the driving impetus for the use of all facets of the "transitional phase." 


\section{Conclusion}

Bill Watterson's Calvin and Hobbes is one of the more complex American comic strips. Philosophy, morality, culture, psychology, child-rearing, and education are just a few of the many themes that are interwoven into the series. As of the writing of this article, Calvin and Hobbes ran its final strip twenty years ago. Despite this fact, the series has remained in syndication in newspapers the world over, and although Watterson attributes the overall success of the series to the immense influence of Charles Schulz's Peanuts comics ${ }^{4}$, the tremendous (and continued) popularity of Watterson's own creation shows that he has earned his place right alongside Schulz in the history of great American comic strips.

Furthermore, while Calvin and Hobbes is not (strictly speaking) a strip written solely for children, it is certainly worthwhile to consider the comic in terms of popular children's narratives, especially considering that the entire series revolves around the adventures of a child and his fantastically anthropomorphic, stuffed tiger. The many parallels between the childhood development theories of D.W. Winnicott and the adventures of Calvin and his pet tiger Hobbes show unequivocally that Watterson has the extraordinary ability to demonstrate the familiar and complicated transitional phase as Winnicott and the object-relations analysts theorized it. However, the preceding analysis is certainly not an attempt on my part to nail down any one cause for the continued success of Calvin and Hobbes. While the child psychology inherent in the series has served as the basis of my exploration of the series, the fact remains that it is only one possible reason-amongst many, many others-as to why

4. "I collected the annual Peanuts books all through childhood, and it's probably impossible to overstate the influence Peanuts had on me" (Complete Calvin and Hobbes 6). 
the Calvin and Hobbes series has continued to maintain a worldwide readership twenty years after the run of its final strip. This fact alone makes the series ripe for varying critical approaches to the comic that have yet to be undertaken; perhaps then, in order to further analyze the myriad nuances of the series, we must continue to engage in sustained critical analyses of Calvin and Hobbes and, indeed, take up the impetus given by Calvin himself in the series' final strip: "Let's go exploring!"

\section{Works Cited}

Abram, Jan, and Harry Karnac. The Language of Winnicott: A Dictionary and Guide to Understanding His Work. Northvale, NJ: J. Aronson, 1997. Print.

Campanelli, John. "Calvin and Hobbes Fans Still Pine 15 Years After Its Exit." The Plain Dealer [Cleveland] 01 Feb. 2010: n. pag. Web. 30 Dec. 2015.

Freud, Anna. Normality and Pathology in Childhood. London: Hogarth, 1966. Print.

Jacobs, Michael. D.W. Winnicott. London: Sage Publications, 1995. Print.

Klein, Melanie. The Psychoanalysis of Children. Trans. Alex Strachey. New York: Grove, 1960. Print.

Watterson, Bill. The Complete Calvin and Hobbes. Kansas City, MO: Andrews McMeel Pub., 2005. Print.

Winnicott, D. W. The Child, the Family, and the Outside World. Harmondsworth, Eng.: Penguin, 1964. Print. 


\title{
3. Traumatic Origins
}

\section{ORPHANHOOD AND THE SUPERHERO}

\author{
Jennifer Duggan
}

Richard Reynolds, in Superheroes: A Modern Mythology, ${ }^{1}$ lists "lost parents" as the first of seven common markers of the superhero genre, stating, "the hero ... often reaches maturity without having a relationship with his parents" (16) and pointing out that "few superheroes enjoy uncomplicated relationships with parents who are regularly present in the narrative" (12). Indeed, orphans have long been central figures in children's and young adult literature. The reasons for their centrality are manifold, ranging from the freedom allowed them by their orphanhood to the pathos they inspire. In the superhero genre in particular, orphans abound-Superman, Daredevil, Robin, Batman, and Spider-Man are all orphans, and their behavior follows a literary precedent.

Reynolds emphasizes superheroes' individuality, and yet, he also lists orphanhood as a central aspect of the superhero 
character and genre. This suggests that while many superheroes are orphans, their circumstances are unique, and for this reason, my paper will compare and discuss the importance of the orphan status and the superhero identities of only two superheroes: Batman and Spider-Man. I have chosen to examine these two superhero orphans because both suffered the violent and traumatic loss of one or more parents or guardians ${ }^{2}$ and responded to these losses in ways that are at times strikingly similar. Both lose their parents through their parents' resisting theft and, resultantly, being shot. For both, this loss is the underlying cause of their crime-fighting vendettas, which both preserves the memories of their parents and prevents the heroes from moving forward as their missions constantly revive their feelings of grief and guilt. This means that the comics' very seriality stems from the heroes' inability to recover from the loss of their parents. Simultaneously, the traumatic pasts of each character and their reactions to loss differ subtly, allowing us to discuss how the trauma of becoming an orphan shapes their identities with some nuance.

Interestingly, many of the reactions to trauma that these two iconic superheroes express directly reflect the tropes of the literary orphan established in the nineteenth and early twentieth centuries. In discussing Batman and Spider-Man's orphanhood, this paper will therefore bring together a discussion of literary orphans and trauma theory to examine why the violent loss of one or both parents and resultant interpersonal trauma cause SpiderMan and Batman to repeatedly and frequently fight crime. It will explore why these vigilantes oscillate between being "good" and 
"bad" in public perception, with reference to the orphan tradition, and it will further seek to show what their superhero identities might represent within this landscape of psychosocial trauma, synthesizing the work of scholars who have previously aimed to understand these superheroes as embodying aspects of trauma with scholars who have explored literary orphanhood.

In short, my paper aims to shed light on why orphanhood is so common in superhero narratives ${ }^{3}$ and in doing so, argues that Batman and Spider-Man would not be superheroes were they not seeking to comprehend, revisit, or atone for past losses. It further argues that the comics evoke the rich tradition of the literary orphan in their characterizations of Batman and Spider-Man and that these traditions reflect and expose the trauma suffered by both superheroes.

\section{Orphan Tradition}

Orphans, real or symbolic, have existed in Anglophone literature for centuries, but the orphans with whom we are most familiar developed in late eighteenth-century literature. During the Victorian and Edwardian periods, ${ }^{4}$ the common characteristics we still find in most literary orphans evolved. Nina Auerbach was one of the first to discuss literary orphans critically. She argues that nineteenth-century orphans are self-fashioning figures, able

3. Although "personal tragedy does not drive all comic book superheroes" (Langley 50 ), it is a very common part of their pasts (and, indeed, their presents).

4. Orphans were visibly present in Antebellum and post-Antebellum America as well as in Britain, as America was essentially a society founded upon real and metaphorical orphans. Indeed, many of the earliest settlers of the American colonies were children and youths transported under King James I's 13 January 1618 order that the "divers idle young people" who loitered near his palace be sent "away to Virginia" and "sett to worke there" as a "deed of charity" (Stewart). Orphans thus became a troubling yet foundational part of American society. See, e.g., Laura Peter's Orphan Texts: Victorian Orphans, Culture and Empire (Manchester UP, 2013). 
to move between social classes with ease because they have no family and "no past to give [them] shape" (397). This lack of social baggage also allows the orphan to "manufacture a self by assuming social definition" (400). However, later incarnations of the orphan invert this idea. They are emblematic of "pure selfhood" (404), able to achieve self-actualization precisely because of their lack of ties and yet more vulnerable to having their identity attacked for the same reason. Often, they are also symbolic of social or political causes, standing in for all those who are poor and abused yet "good" at heart, as in Dickens's novels.

This idea of orphans as essentially good reflects the pathos and empathy with which authors intended audiences to perceive them. Indeed, late-Victorian philanthropists at times "manipulated ... popular images of poor children in order to promote their cause," using "melodrama" and "preexisting narrative structure[s]" to create sympathy through their advertisements for charitable donation (Murdoch 14), building on images from social reform literature that position the orphan a sympathetic figure (Murdoch). ${ }^{5}$ Social reformist or philanthropic narratives often reward good orphans with reentrance into mainstream social structures: they discover their place within their bloodline or find a new family through, for example, marriage or adoption. ${ }^{6}$

And yet late nineteenth- and early twentieth-century authors sometimes characterized orphans as dangerous for many of the

5. Famous examples include W.T. Stead's "The Maiden Tribute of Modern Babylon" (1885) and Thomas John Barnardo's numerous publications. Lydia Murdoch argues that Dickens's crossing sweeper Jo, from Bleak House (1852-3), remained emblematic of the orphaned street child throughout the nineteenth century (20-1). Tamara Wagner suggests that the "undisguised sentimentality with which the orphan hero is portrayed" makes the eponymous Oliver Twist (1837-9) one of the most memorable Victorian orphans (68). See also Joe Sutliff Sanders's article "Spinning Sympathy: Orphan Girls and the Sentimental Tradition."

6. Other examples include Charlotte Brontë's fane Eyre (1847) and Jane Fairfax from Jane Austen's Emma (1815). 
same reasons earlier authors characterized them as good-because they defied social classification; because they had no families, the important central unit of society; because they symbolized both pure selfhood and, simultaneously, an empty shell clothed in their own self-made identities; because they had so much freedom; because their identities were malleable and subject to manipulation by both themselves and others. ${ }^{7}$

Orphans therefore became paradoxical figures to be both pitied and feared, signaling either the fulfillment of potential or its loss, and they often metamorphosed to reflect their inner moral state, good or bad (Floyd 6). They appear, metaphorically and literally, as dark in both their character and appearance, the latter due both to racialization and to the soot and dirt that covered street orphans (Murdoch 24-35). David Floyd argues that towards the end of the nineteenth and into the early twentieth century, the orphan figure came to display "a notable incredulity and confidence, and tended to depend less on the intervention of ... adult[s] ... and more on his or her own exertion of will and creativity" (8). ${ }^{8}$ The orphan became a fragmentary figure, a site of fin-de-siècle anxieties about the malleability and ephemerality of the self and identity. In some cases, the severe "emotional and psychic trauma endured" by orphans caused them to become monstrous, abnormal, destructive figures unable to fit into society or follow its rules (Floyd 11-3). Late nineteenth- and early twentieth-century literature, press, and even political and philanthropic discussions depict orphans as racially, morally, and

7. A notable example is Vanity Fair's Becky Sharp (1847-8). Even Oliver has a foil-the Artful Dodger-allowing Dickens to display "a spectrum of criminal children that showcases uncertainties about corruption and ... an ambiguity that was central to nineteenth-century discourses on endangered childhood" (Wagner 69-70). See also Mara Gubar's book Artful Dodgers: Reconceiving the Golden Age of Children's Literature.

8. Think, for example, of Peter Pan. 
biologically different, wild and tribal to the point of being "animalistic or subhuman" (Murdoch 26).

In short, because orphans are able to escape social limitations to identity, like family or class, and because their histories and contexts are implicitly obscure, they are able to fashion their own identities. Furthermore, they are better able to don identities appropriate to the social contexts within which they find themselves. This flexibility of identity and social freedom means that, in literature, they are either being extremely good or extremely bad, but never entirely "normal."

\section{Orphan Superheroes and Trauma}

Spider-Man and Batman were born in the popular press. Their origin stories are therefore fuzzy, sometimes even contradictory. With time, these origin stories have been told and retold, as well as refined, with small details removed, added, or changed. It is worth noting that these shifting, changing histories reflect the anxieties expressed about orphans in literature more generally. As suggested above, orphans, because of their lack of ties, are better able than most to shape their own history. They are often the only witness to their lives as a whole and are thus able to construct and reconstruct their pasts as they desire, even unconsciously. This "fuzziness" reflects both their fragmented nature and the uncertainty of their past. But while details shift and change, the core story remains the same: Batman witnesses the shooting, death, and robbery of his parents; Spider-Man believes he causes the subsequent shooting death of Uncle Ben through his own inaction. These traumatic losses kindle both boys' desire to don

9. We can see this, for example, in Barrie's depiction of the Lost Boys in Peter Pan, who run about "in the skins of animals they think they have shot" and only vaguely recall "the days before [they were] lost, with their manners and customs" (106). 
costumes and fight crime, and thus orphanhood is central to their superhero identities.

Previous research has largely discussed superheroes as metaphors for other orphanings, such as the orphaning of Jews during the Second World War, the movement of individuals from the country to the city, or the need to build an identity unrelated to family. ${ }^{10}$ However, superheroes have not been discussed as embodying previously established tropes of literary orphans' identities, and neither have these previously established tropes been clearly linked to the trauma of losing one's parents. The trauma of orphanhood is therefore central to the identities of orphaned superheroes, and particularly of Batman and SpiderMan, in a manner that goes beyond and subsumes survivor's guilt or other psychological reactions to trauma. ${ }^{11}$

Ronnie Janoff-Bulman defines trauma as "confrontation with mortality, real or symbolic, and with our own fragility" (xii). Trauma arises from the shattering of our basic assumptions about life, such as that the world is good and that we ourselves, whom we self-construct as good, will not suffer harm. Because these assumptions are central to our understanding of ourselves, traumas-which shatter these assumptions-also make us question who we are, what we are worth, and how we fit into society. We continue to revisit the assumptions we have lost and to experience their loss as "mysterious, dangerous, contradictory, horrific, mortifying, [and] uncanny" (Kauffmann 3) while we attempt to

10. See, e.g., McWilliams; Anders; Wandtke 56-7, 62.

11. Batman's troubled past has drawn comments that he may suffer from a psychiatric disorder such as PTSD. Travis Langley reminds us that "losing one's parent or parents ... [is] the single most stressful ... life event children can experience” (37), but despite this, he argues that Batman does not suffer from PTSD. S. Taylor Williams, however, believes that Batman does exhibit symptoms of PTSD and that the traumatic pasts of superheroes help audiences to sympathize and empathize with these characters. 
come to terms with our trauma. Thus, a traumatic event is not located at a single point in time but includes the continued revisiting of loss.

Children often hold the basic assumption that the world around them is "kind, protective, safe, consistent, and meaningful" and that their parents or guardians "will be there to provide love, protection, and meaning" (Goldman 194). Young children routinely view their parents as infallible and look up to them as role models. For orphans, then, the loss of one or both parents to a violent criminal act is a traumatic experience that not only shatters their assumption that their parents will always be there to provide love and protection but also their assumption that the world is a good place. Those who suffer the loss of or "abandonment ... by their caretakers" are therefore more likely to demonstrate "complex psychobiological disturbances" than victims of other traumas (van der Kolk and d'Andrea 57). Childhood interpersonal traumas can "affect regulation, attention, cognition, perception and interpersonal relationships" and often result in "explosive anger, self-destructive behavior, ... social withdrawal, ... risk taking, ... oppositional behavior and reenactment of trauma," as well as "distortions in self-perception and systems of meaning" and interpersonal difficulties, such as "poor boundaries" (van der Kolk and d'Andrea 57-8, 62), all characteristic of Batman and SpiderMan's personalities and, indeed, representative of literary orphans more generally.

\section{Repetition and Trauma}

A number of theorists have discussed the traumas that Batman and Spider-Man suffer. Spider-Man's loss of his Uncle Ben as a teenager spurs his desire to fight crime. Terrence R. Wandtke states, "the guilt that will motivate [Spider-Man] as a costumed 
crime fighter is not too different from the revenge motive of Batman" (125), and Forrest C. Helvie posits, "the traumatic event in [Spider-Man's] life changed him.... The death of his Uncle Ben serves as the moment of his being fractured apart from his community, and [the locus of] his continual attempt to return that broken community to its state of wholeness" and to "correct the mistakes of the past by preventing similar forms of trauma from being inflicted upon others" (148-9).

Helvie postulates that reenactment of a trauma "serves as a means by which the traumatized subconscious attempts to right itself by reenacting the events that caused the disruption" and create a different outcome to the original traumatizing event or heal (151). However, he simultaneously argues that the "adoption of the Spider-Man persona [is] an attempt to develop a new identity script to perform-one whose identity is a clean slate, and therefore free of the traumatic death of his 'father'" (151). These two statements are unfortunately somewhat contradictory, for if the reenactment of a trauma suggests that the traumatized is attempting to heal, and if Spider-Man's crime fighting is seen as a reenactment of his loss, then the Spider-Man identity must instead be an embodiment of the trauma that the superhero has suffered-a physical representation of his psychical trauma. Although he cannot, as Peter, allow himself to suffer-he must get on with his life, find a career, and support his aunt-Spider-Man serves as an eruption of his compulsion to repeat the traumatic event in order to create a different outcome, a representation of the fragmentation he feels. Thus, Spider-Man compulsively fights crime, doing what he failed to do at the start of his journey, in a continual effort to undo the past and retroactively save a man who can never be saved: Uncle Ben.

One of the main "symptoms" discussed by critics is Batman's constant return to the traumatic murder of his parents. As Batman 
himself explains, "The future's always in the process of interpreting the meaning of the past" (Tomasi, Gleason, and Gray). His comment reflects Cathy Caruth's suggestion that "knowing and not knowing are entangled in the language of trauma and in the stories associated with it" (4), for "what returns to haunt the victim ... is not only the reality of the violent event but also the reality of the way that its violence has not yet been fully known" (6). Batman's continual dwelling upon his moment of loss, then, is his continued attempt to grasp its slippery and changing meaning to his life. As Caruth reminds us,

the story of trauma, ... as the narrative of a belated experience, far from telling of an escape from reality ... rather attests to its endless impact on a life.... At the core of these stories [of trauma] ... is a kind of double telling, the oscillation between a crisis of death and the correlative crisis of life: between the story of the unbearable nature of an event and the story of the unbearable nature of its survival. (7)

Both Langley and Martyn Pedler argue that Batman does not actively avoid thinking about his parents' murders; rather, his continual return to his memories of their murder-which are, in most cases, purposeful reflections rather than unbidden, intrusive recollections-continually reaffirm his desire to fight crime. Pedler reminds us that Batman surrounds himself with artifacts reminding him of his parents' death: "the secret entrance to the Batcave is opened by moving the hands on a grandfather clock to show the minute of the Waynes' death.... [In Legends of the Dark Knight \#6, Batman sits] ... under a portrait of his dead parents in a whole room full of stopped clocks" (10). Indeed, in Batman and Robin: Born to Kill, Robin points out that "all the locks and 
passwords are set for that specific number" (Tomasi, Gleason, and Gray), and Batman continually reminds the reader that he fights crime for the sake of his parents, or, as is suggested above, so that he can understand the trauma of their loss. However if, as Caruth suggests, healing from a trauma is in essence allowing oneself to forget, Batman can never heal. He does not want to forget, for remembering and mourning give his life purpose and meaning.

In Beyond the Pleasure Principle, Freud discusses this need to repeat traumatic events, referred to in theory as repetition compulsion. The compulsion to repeat is, to Freud, an action completed in order to come to terms with death and mortality, an "impulse to work over in the mind some overpowering experience so as to make oneself master of it" (10). Thus, those who have suffered a traumatic event are compelled to reenact it in some way until they achieve a sense of mastery or resolution. This repetition may further spur traumatized individuals to transfer their aggressions or affections onto people or objects other than those originally involved. ${ }^{12}$ Batman and Spider-Man, for example, transfer their negative emotions from their parents' murderers to any criminal and their positive and protective emotions to any victim of crime. They are thus more willing to take personal risks to save victims of criminals than they otherwise would be. Transference and repetition compulsion suggest, therefore, that the violent death of their parents is the motivating factor for their crime-fighting endeavors: both repeatedly duplicate the event that caused their loss, working towards a closure they are unlikely to achieve; both transfer their anger and desire for revenge from a single perpetrator of a crime to all criminals; both are compelled to act in the way they wish they had acted when their parents were killed (stopping criminals) until they achieve mastery. However, 
mastery remains out of reach, as no matter how many criminals they put behind bars, they remain unable to save their deceased loved ones and unable to stop crime altogether. Spider-Man and Batman never feel as though they are in control of the situation. They must instead continue to revisit the trauma in an endless attempt to gain control and exert their mastery.

Batman, for example, states the following in the first incarnation of his origin myth: "I swear by the spirits of my parents to avenge their deaths by spending the rest of my life warring on all criminals" (Kane). Seeking to avenge his parents drives his continued existence as Batman, whose responsibilities and vendetta are almost always prioritized above those of his civilian self, Bruce Wayne. That he is seeking not only to avenge but to undo the moment of his parents' deaths is emphasized in Origin of Batman, First Batman, and Detective Comics 500, as Reynolds reminds us. These comics allow Batman not only to kill those responsible for his parents' deaths but also to retroactively save other incarnations of his parents in an alternate reality. Ultimately, however, none of these actions satisfy, as "no amount of successful crimefighting can ever undo his parents' death or alleviate the guilt to which [he] is perpetually subjected" (Reynolds 67). Indeed, as both Pedler and Reynolds argue, to allow Batman to achieve closure would defeat the purpose of the serial comic, for "complete atonement might spell retirement, which continuity can never permit" (74). ${ }^{13}$

Similarly, Spider-Man expresses guilt for not having stopped the murderer of his uncle "when [he] had the chance" (Lee and Ditko). He repeatedly calls his uncle's death "my fault" and learns

13. Pedler briefly discusses narrative circularity and recurring references to superhero origin traumas in his unpublished conference paper "Suffering and Seriality," although his paper focuses on repetition and atemporality as a function of comics' seriality rather than as a reaction to trauma. 
that he should stop criminals early (Lee and Ditko). The final panel of his original origin story, emphasizing his feelings of guilt and loss, is captioned as follows:

And a lean, silent figure slowly fades into the gathering darkness, aware at last that in this world, with great power, there must also come-great responsibility! And so a legend is born and a new name is added to the roster of those who make the world of fantasy the most exciting realm of all! (Lee and Ditko)

This caption underscores the necessity of loss to the superhero narrative by linking loss to the excitement of fantasy. In the panel, Spider-Man stands alone on a street at night, silhouetted against the dark sky, surrounded by dark buildings, with his head bowed. He is made to look small and distant. Unlike in the other panels, in which bright colors are in the majority, only dark, cold colors are used in the background, expressing his feelings of loss and guilt. The only splashes of color are his red costume and the yellow moon.

Langley suggests Batman's crime fighting is a purposeful immersion in reminders of the loss of his parents, a satisfying if painful reopening of an old psychological wound, while Marc DiPaulo proposes that Batman's childhood trauma and the resulting anger and frustration he feels result in the superhero's arrested development: Batman remains "a frightened and angry child" who views the world "in stark black-and-white morality" (55-6). Indeed, if Eric Tribunella's suggestion that, in life and in literature, "love and loss work as a catalyst for maturation" (xi), then Batman and Spider-Man's continued dwelling on their losses could indeed mark an inability to fully mature, a perpetual youthfulness. Both Batman's and Spider-Man's desire to fight 
crime stems from guilt or a desire to avenge their parents. If we consider what we have learned about trauma, repetition compulsion, and orphan status, we can further interpret their continual desire to fight crime as a desire to retroactively prevent the losses they have suffered; each is trying, ineffectually, to save his parent(s), and each believes that preventing all crime will in some way retroactively prevent the deaths of his parent(s).

\section{Fragmentation}

Batman and Spider-Man's superhero aliases clearly relate to their being orphans. As we have seen above, orphans are characterized by a fragmented nature as well as by an ability to self-fashion their own identities. We can see this self-fashioning very clearly in incarnations of superhero orphans: as civilians, both Batman and Spider-Man attempt to act as though they have gotten over the loss of their parents, but by allowing themselves to have superhero aliases and, in those guises, to seek to heal the traumas they have suffered, they are able both to act functionally as civilians and to attempt to come to terms with their traumas in a way that does not affect their day-to-day lives as Peter Parker and Bruce Wayne. As I briefly argued above, their costumed identities can therefore be read as physical representations of psychological traumas, fragmentations made flesh.

A creature of the night, Batman evokes earlier depictions of orphans as animalistic, wild, and uncontrollable. His superhero persona hints at an obsession bordering on instability. The Oxford English Dictionary suggests that battiness has two meanings: (1) "of or belonging to a bat, bat-like" and (2) "eccentricity" or "madness." The Corpus of Historical American English suggests that use of batty to connote madness or obsession peaked in America between 1910 and 1949, ${ }^{14}$ precisely when Batman came into being. 
As Dennis O'Neil suggests, "Batman permits his obsession to be the meaning of his life" (Pearson and Urucchio 21), and Batman himself describes his parents' murder as "the time that all sense left my life" (Tomasi, Gleason, and Gray).

Spider-Man's costume similarly depicts him as a creature of the night and of shadows. Intriguingly, both spiders and bats reflect the paradox of the orphan figure: both are good and bad, for while both get rid of vermin, they are also viewed as vermin themselves. This characterization of both Spider-Man and Batman as both helpful to and dangerous for society reflects this paradox. As Helvie reminds us, traumas can define individual identity: "Trauma creates a lasting shift within the individual's psyche, whose effects will remain a part of that individual's conception and performance of self" (149).

Both Spider-Man and Batman embody their trauma in their superhero costumes and personas. Indeed, the first thing Peter does after learning of his Uncle Ben's shooting from a police officer is to run upstairs, crying, to change into his Spider-Man costume so that he can hunt down the murderer, and the first thing he does when dressed as Spider-Man is to "relieve [his uncle's killer] of [the] gun" that killed his uncle (Lee and Ditko). Bruce Wayne, meanwhile, is shown to contemplate which animal would strike fear into the hearts of his enemies, stating, "My disguise must be able to strike terror into their hearts. I must be a creature of the night, black, terrible" (Kane). ${ }^{15}$

Furthermore, although both Spider-Man and Batman feel their crime fighting is just, their motives are often questioned by the populace and the police. At times, their behavior mirrors

14. For example, "to be batty for or over someone or something" suggests an obsessive love of that person or thing, as evidenced in the Corpus of Historical American English.

15. I cite the original versions of the origin stories here. There are, of course, other manifestations. 
that of their enemies, exhibiting destructiveness and an apparent disdain for societal rules. For example, when Spider-Man attempts to save his girlfriend Gwen in "The Green Goblin's Last Stand," he instead accidentally kills her, after which he punches a police officer. In the same issue, the press and police label him the murderer of Norman Osborn. In his grief, a full-page splash shows him to be haunted by those for whose deaths he blames himself, including both Gwen and Uncle Ben (Conway).

More, it is made clear through the characterization of the villains Batman and Spider-Man face that they could just have easily have reacted to their parents' murders with negative, destructive behavior. For example, the Joker is a character foil for Batman, an image of what his anger might have done to him, or perhaps even symbolic of the darker parts of himself he fights, a psychic specter who is always breaking out of Arkham Asylum, while Batman is continually wrestling him back into captivity. ${ }^{16}$ Indeed, the Joker suggests that loss of reason is a natural reaction to trauma: "When you find yourself locked onto an unpleasant train of thought, heading for the places in you past where the screaming is unbearable, remember there's always madness. Madness is an emergency exit" (Moore and Bolland).

\section{Conclusion}

The heroes' behavior and costumes underscore their characterization as both an integral part of society and fundamentally apart from society, as dangerous as they are helpful. ${ }^{17}$ This contradictory placement emphasizes their loneliness and the losses they have suffered. Literary orphans

16. For a discussion of the Joker as a completion of Batman, see Michael Goodrum's "'You Complete Me': The Joker as Symptom." See also Reynolds, 67-8, and Pearson and Uricchio's "I'm Not Fooled by That Cheap Disguise." 
exhibit not only a desire to develop an identity that would allow them to fit into society but also a feeling of being somehow excluded from society. The fragmented nature of the orphaned superhero reflects this liminality. We can therefore say of superhero orphans like Batman and Spider-Man that their superhero identities are an eruption of trauma, an expression of the things they attempt to keep separate from their civilian lives. They feel the need to assuage a wound that can never truly be healed, and in order to do that, they don costumes and fight crime, repeatedly attempting to memorialize or retroactively save the parents whose deaths left them fragmented, guilty, angry, and vengeful.

\section{Works Cited}

Anders, Lou. "A Tale of Two Orphans: The Man of Steel versus the Caped Crusader." The Man from Krypton: A Closer Look at Superman. Ed. Glen Yeffeth. Dallas: Benbella, 2005. 69-76. PDF file.

Auerbach, Nina. "Incarnations of the Orphan." ELH 42.3 (Autumn 1975): 395-419. FStor. Web. 19 Nov. 2015.

Barrie, James. "Peter Pan." Peter Pan and Other Plays. Oxford: Oxford UP, 2008. 73-154. Print.

Batty. Corpus of Historical American English. Web. 5 Jan. 2016. Batty, adj. Oxford English Dictionary Online. 2013. Web. 5 Jan. 2016.

17. A number of scholars have interpreted the outsider status of the superhero in other ways. Steve Ditko emphasizes the libertarian nature of individuality, citing, e.g., Ayn Rand as an important influence on his superheroes' exceptional and individual natures (Chad K.W.D.L.). See also the works listed in footnote 10 and Bradford Wright's Comic Book Nation (John Hopkins UP, 2001). 
Caruth, Cathy. Unclaimed Experience: Trauma, Narrative, and History. Baltimore: John Hopkins UP, 1996. Project Muse. Web. 1 Jan. 2016.

Conway, Gerry. “The Green Goblin's Last Stand!” Amazing SpiderMan Jul. 1973. YouTube. Web. 16 Dec. 2015.

-. “Just a Man Called Cage." Amazing Spider-Man Aug. 1973. YouTube. Web. 16 Dec. 2015.

Coogan, Peter. Superhero: The Secret Origin of a Genre. Austin: Monkey Brain, 2006. PDF file.

DiPaulo, Marc. War, Politics and Superheroes: Ethics and Propaganda in Comics and Film. Jefferson and London: McFarland and Company, 2011. EBL. Web. 3 Jan. 2016.

Chad K.W.D.L. Masters of Comic Book Art-Eisner, Kirby, Ditko, Adams, Wrightson, Miller-1987. Writ. Harlan Ellison. Dir. Ken Viola. YouTube. 25 Sept. 2015. Web. 2 Mar. 2016.

Floyd, David. Street Urchins, Sociopaths and Degenerates: Orphans of Late-Victorian and Edwardian Fiction. Cardiff: U of Wales P, 2014. ProQuest ebrary. Web. 3 Sept. 2015.

Freud, Sigmund. Beyond the Pleasure Principle. Trans. James Strachey. Int. Gregory Zilboorg. London and New York: W.W. Norton \& Company, 1961. PDF file.

Guber, Marah. Artful Dodgers: Reconceiving the Golden Age of Children's Literature. New York: Oxford UP, 2009. http://dx.doi.org/10.1093/acprof:oso/

9780195336252.001 .0001

-. An Outline of Psychoanalysis. International fournal of Psychoanalysis 21: 27-84. PDF file.

Hatfield, Charles, Jeet Heer, and Kent Worcester, eds. The Superhero Reader. Jackson: UP of Mississippi, 2013. ProQuest ebrary. Web. 4 Jan. 2016.

Helvie, Forrest C. "The Loss of the Father: Trauma Theory and the Birth of Spider-Man." Web-Spinning Heroics: Critical Essays 
on the History and Meaning of Spider-Man. Ed. Robert Moses

Peaslee and Robert G. Weiner. Jefferson: McFarland \& Company, 2012. Google Play eBook. 146-53.

Janoff-Bulman, Ronnie. Foreword. Loss of the Assumptive World: A Theory of Traumatic Loss. Ed. Jeffrey Kauffman. New York and London: Brunner-Routledge, 2002. xi-xii. PDF file. Jenkins, Harry. "Death-Defying Heroes." The Superhero Reader. Ed. Charles Hatfield, Jeet Heer, and Kent Worcester. Jackson: UP of Mississippi, 2013. ProQuest ebrary. Web. 4 Jan. 2016.

Kane, Bob. "Batman." Detective Comics 1 Nov. 1939: n.p. PDF file. Kauffman, Jeffrey. Introduction. Loss of the Assumptive World: A Theory of Traumatic Loss. Ed. Jeffrey Kauffman. New York and London: Brunner-Routledge, 2002. 1-12. PDF file.

Langley, Travis. Batman and Psychology: A Dark and Stormy Knight. Hoboken: Wiley, 2012. EBL. 5 Jan. 2016.

Lee, Stan, and Steve Ditko. "Spider-Man!" Amazing Fantasy Aug. 1962: n.p. Marvel Unlimited. Web. 10 Dec. 2015.

McWilliams, Ora. "'Hey Batman, What Are Your Parents Getting You for Christmas?': The Orphan Narrative and Non-Traditional Families in American Superhero Publications." MA Thesis. Bowling Green University, 2009. ProQuest. Web. 11 Oct. 2015.

Moore, Allan, and Brian Bolland. The Killing foke. New York: DC Comics, 2008. Print.

Murdoch, Lydia. Imagined Orphans. New Brunswick: Rutgers UP, 2006. Project Muse. Web. 4 Dec. 2015.

Pearson, Roberta, and William Uricchio. "Notes from the Batcave: An Interview with Dennis O’Neil." Many More Lives of the Batman. Ed. Roberta Pearson, William Uricchio, and Will Brooker. 2nd ed. London: Palgrave, 2015. 21-32. Google Books. Web. 4 Jan. 2016.

-. "I'm Not Fooled by That Cheap Disguise." PDF file. 
Pedler, Martyn. "Suffering and Seriality: Memory, Continuity, and Trauma in Monthly Superhero Adventures." Media in Transition 5: Creativity, Ownership, and Collaboration in the Digital Age. Massachusetts Institute of Technology. Kendall Square, Boston, MA. 27-29 Apr. 2007. Conference presentation. Web. 5 Jan. 2016. Reynolds, Richard. Superheroes: A Modern Mythology. Jackson: UP of Mississippi, 1992. Print.

Sanders, Joe Sutliff. "Spinning Sympathy: Orphan Girl Novels and the Sentimental Tradition." Children's Literature Association Quarterly 33.1 (2008): 41-61. http://dx.doi.org/10.1353/ chq. 2008.0005

Stewart, King James I. Letter to Sir Thomas Smyth. 13 January 1618. London Metropolitan Archives, London. "Did You Know?" On Their Own: British Child Migrants. Australian National Maritime Museum and National Museums Liverpool. 2010. Web. 5 September 2015.

Tomasi, Peter J., Patrick Gleason, and Mick Gray. Batman and Robin: Born to Kill. New York: DC Comics, 2011. Print.

Tribunella, Eric. Introduction. Melancholia and Maturation: The Use of Trauma in American Children's Literature. Knoxville: U of Tennessee P, 2010. ProQuest. Web. 10 Jan. 2016.

van der Kolk, Bessel A., and Wendy d'Andrea. "Towards a Developmental Trauma Disorder Diagnosis for Childhood Interpersonal Trauma." The Impact of Early Childhood Trauma on Health and Disease: The Hidden Epidemic. Ed. Ruth A. Lanius, Eric Vermetten, and Clare Pain. Cambridge: Cambridge UP, 2010. 57-68. ProQuest. Jul. 2010. Web. 11 Dec. 2015.

Wagner, Tamara. "The Making of Criminal Children: Stealing Orphans from Oliver Twist to A Little Princess." Victorians: A Journal of Culture and Literature 121 (2012): 68-83. Gale. Web. 6 Jan. 2016. 
Wandtke, Terrence R. The Meaning of Superhero Comic Books. Jefferson: McFarland \& Company, 2012. EBL. Web. 3 Jan. 2016. Williams, S. Taylor. "'Holy PTSD, Batman!:' An Analysis of the Psychiatric Symptoms of Bruce Wayne." Academic Psychiatry 36.3 (May-June 2012): 252-255. Springer Link. 4 Jan. 2014. Web. 22 Dec. 2015. 


\section{Striking Camp}

\section{EMPOWERMENT AND RE-PRESENTATION IN \\ LUMBERJANES}

Kyle Eveleth

"I solemnly swear to do my best

Every day, and in all that I do,

To be brave and strong,

To be truthful and compassionate,

To be interesting and interested,

To pay attention and question

The world around me,

To think of others first,

To always help and protect my friends,

[line scribbled out; handwritten:] then there's a line about God, or whatever

And to make the world a better place

For Lumberjane scouts

And for everyone else."

The Lumberjanes Pledge 
The Eisner-award-winning serial comics series Lumberjanes (2014-present), crafted by the Hardcore Lady-Type squad of writers Shannon Ellis, Grace Waters, Noelle Stevenson, and a bevy of hardcore guest artists, ${ }^{1}$ has been lauded by critics like Alison Berry as "the book so many have asked for, both accessible and girl friendly without sacrificing entertainment value for the older set" (Berry, n.p.). ${ }^{2}$ Spinning the deep-woods tale of the eponymous Lumberjanes troop of Miss Quinzella Thiskwin Penniquiquill Thistle Crumpet's Camp for Girls Hardcore Lady Types, Lumberjanes simultaneously revitalizes and revises the centuryold scouting girl genre of popular fiction that was made lucrative by the Edward Stratemeyer Syndicate in the late 1910s and thrived until the 1940s. Following a slew of other popular multimedia reformulations of the summer camp story, such as Wes Anderson's critically-acclaimed film Moonrise Kingdom (2012) and Katie Rice's award-winning webcomic Camp Weedonwantcha (2013-present), Lumberjanes captures the exploratory mysticism of camp stories without rehashing their problematically narrow depictions of gender, sexuality, racial hierarchy, and American imperialism (more on that later). Rather, Lumberjanes deftly and thrillingly foregrounds opportunities for scouts to covertly or overtly resist

1. As a staunch proponent of equally recognizing all the contributors involved in large-scale comics creation, I list here the creative team that has worked on Lumberjanes issues 1 through 20. Writers: Noelle Stevenson, Grace Ellis, Shannon Watters, Faith Erin Hicks; Artists: Brooke A. Allen, Brittney Williams, Aimee Fleck, Faith Erin Hicks, Becca Tobin, Carolyn Nowak, Felicia Choo, T. Zysk; Letterer: Aubrey Aiese; Colorist: Maarta Laiho; Editor: Dafna Pleban.

2. Lumberjanes is a continuing comics series. As of the end of 2015, it is on its 21st issue; the first twelve are collected in trade paperbacks, cited at the end of this essay, but the best way to get the story in its entirety is to visit the local comic-book dispensary. As with most comics, they do not have page numbers; I have given issue number and approximate pagination where necessary. 
the sometimes pernicious gendering of appropriate scouting activities and naturalization of sexual difference that have long characterized the scouting movement and indeed novelizations of it.

The scouting novel tradition from which Lumberjanes draws its form was short-lived but intensely influential for popular conceptions of what it meant-and, indeed, still means-to be a scout. Enjoying their heyday between the 1910s and the 1940s, scouting novels encapsulated and fictionalized the nascent scouting movement. Sarah L. Peters explains that the scouting movement aimed be an outdoor panacea for rising "fears that the forces of modernity had brought about a crisis of masculinity," a cure that would toughen up "boys [...] overcivilized and weakened by technological advances that distanced them from the natural world and their primitive drives" (Peters 57). Driven by these perceived threats to gender roles, the scouting movement was launched by such figures as Lord Robert Stephenson Smyth Baden-Powell, author of Scouting for Boys (1908) and Ernest Thompson Seton, creator of the Woodcraft Indians (1902) to reconnect boys and girls with their "natural" roles. Girls were eventually offered separate-but-equal scouting groups, Luther and Charlotte Gulick's Camp Fire Girls (1911) and Juliette Gordon Low's Girl Scouts (1912), which, despite their focus on outdoor activity and Theodore Roosevelt's "strenuous life,"3 were never

3. The phrase comes from an April 1899 speech Roosevelt delivered at the Hamilton Club in Chicago, in which Roosevelt calls upon young Americans (men especially) to "lead clean, vigorous, healthy lives" of "toil and effort, of labor and strife." By turns profoundly racist, nativist, and pro-war-it is the speech from which the notion "the army and navy are the sword and the shield which this nation must carry if she is to do her duty among the nations of the earth"-Roosevelt's call to action preyed upon twin concerns in the greater American psyche: fear of overrun by foreign hordes (the 1898 Treaty of Paris effectively ended the Spanish-American war and granted the US Puerto Rico, Guam, and the Philippines) and fears of laziness driven by burgeoning modern ease. 
meant to subvert gender norms (Inness 93). ${ }^{4}$ Sherrie A. Inness historicizes boys' scouting, defining the movement's early groups as "pseudo-military organizations for boys that would provide the discipline of a military unit during a non-war period" (91). Susan A. Miller, analyzing Camp Fire Girls creator Luther Gulick's letters and other documents outlining the burgeoning Camp Fire Girls organization, notes that the goal of the Camp Fire Girls was to "develop womanly qualities in the girls" (15). Further, Helen Buckler, Mary F. Fiedler, and Martha F. Allen report in Wo-HeLo: The Story of Camp Fire Girls (1961) that Gulick "wish[ed] to develop girls to be womanly" because "to copy the Boy Scout movement would be utterly and fundamentally evil, and would probably produce ultimately a moral and psychological involution" (qtd. in Buckler 22). Thus, though girls were allowed to be outdoors and take part in more strenuous activities than they would in, say, church groups, their excursions were always founded upon honing "womanly qualities"-skills like social mediation, community activism, and housekeeping rather than riflery, archery, or wayfinding.

Scouting novels, rarely officially sanctioned by the organizations they depicted, reified these conservative gender roles. They were not complex, thoughtful literature. Rather, they were a marketing ploy designed by the enormous Stratemeyer Syndicate (producers of other gendered works like Nancy Drew and The Hardy Boys) to capture the hearts, minds, and increasingly

4. Despite the largely oppressive gender expectations espoused by the scouting movement's major players, there has been a relatively recent trend since 1999 to examine individualized resistance within scouting. See Susan Charles T. Groth's "Scouts' Own: Creativity, Tradition, and Empowerment in Girl Scout Ceremonies," Dissertation: University of Pennsylvania, 1999; Laureen Tedesco, "A Nostalgia for Home: Daring and Domesticity in Girl Scouting and Girls' Fiction, 1913-1933," Dissertation: Texas A\&M, 1999; and Tedesco, "Progressive Era Girl Scouts and the Immigrant: Scouting for Girls (1920) as a Handbook for American Girlhood,' Children's Literature Association Quarterly 31.4 (2006): 346-368. 
disposable allowances of middle-class white American youths. To that end, books for all the major players in the scouting world were published, but the most commonly available and widely read targeted Boy Scouts, Girl Scouts, and Camp Fire Girls. Riding on the coattails of the exploding scouting movement, the works were largely formulaic and moralistic adventure stories that affirmed the pioneer mythology of American culture while appealing to the essentialism of gender difference. Inness describes scouting novels as "churned out by the score by various obscure writers working for slim salaries" and as invariably "approximately 225 pages long, hardbound, [...] cost[ing] a nominal fifty to seventy-five cents" (93). The iconic Boy Scout, mobilized both by the mythology promoted by the organization itself and in the wildly popular but still unsanctioned "Boy Scout" books, ${ }^{5}$ is invariably as good a shot as Wild Bill Hickock, as skilled a pioneer as Daniel Boone, and as courageous a woodsman as Paul Bunyan or, for maximal patriotism, as a young Teddy Roosevelt. He is a paragon of truth, justice, and the American way, his adventures taking him from perilous Pacific shining sea to patriotic Atlantic shining sea, and when he is not in the woods, he uses his impeccable marksmanship to save beautiful, virginal, white middle-class girls from "vile, leprous Chinamen" (Hoover 229). ${ }^{6}$ The fictive "Girl Scout" or "Camp Fire Girl" was as peerlessly domestic as her brother was masculine. Real-life girl scouts, Inness explains, were

5. It is at first bewildering why organizations as concerned with preserving an image as scouting groups would not send takedown notices to the Stratemeyer Syndicate for clear copyright infringement. However, the popularity of the books correlated with booming scouts enrollment despite severe economic downturn and two world wars, suggesting that longtime publisher and Boy Scouts co-creator, William D. Boyce, may have benefited from the free publicity the unsanctioned novels afforded.

6. For more on the intriguing relationship between the American fascination with sharpshooting, pioneer mythology, and the NRA, see Jay Mechling, "Boy Scouts, the National Rifle Association, and the Domestication of Rifle Shooting," American Studies 53.1 (2014): 5-25. 
roped into a "moral crusade" to keep an orderly, clean, and hygienic home (Inness 95). This ideology of "cleanliness is next to godliness" is reproduced in scouting fiction, which Inness argues is "very much aware of its responsibility to instruct young girls about socially acceptable gender behavior" (95). Thus, fictive Girl Scouts become "nicely trained little helpers for the home" (Garis 16; qtd. in Inness 95). Ellen Singleton explains that "girls went to camp to learn to keep house. If they did not want to be homemakers, they went to camp to learn why they should" (66). Carolyn Carpan notes that the books relentlessly championed "domesticity, femininity, and heterosexual romantic love" such that girls in the stories "learn such domestic skills as cooking and basic nursing care, even while they are camping" (39). Learning these skills is all subordinate to the ultimate goal of finding a suitable husband (perhaps a Scout himself). Inness contends that the flash of outdoor activity represented in scouting fiction is merely a lure that "depicts scouting as offering [girls] escape from stereotypical gender roles" (93). But ultimately, Singleton reminds us, "romantic love and a life lived happily ever after were the incentives held out to 'womanly' females, and innumerable examples were presented in these stories to young readers" (67). The reward for learning domesticity and going on romps in the woods is a husband and domestic security.

Lumberjanes borrows many of these familiar elements of scouting novels, both male and female. Set in idyllic, pristine woodland camps, Lumberjanes depicts the iconic scout "always undaunted, always high-spirited"-always prepared, as it were- to safely negotiate "dangers that would be insurmountable to nonscouts" (Inness 93). The covers of most scouting girl novels feature a high-quality, "colored picture of a group of girls engaged in some scouting activity" (Inness 92). Lumberjanes continues this trend with its covers, featuring the ladies of the Lumberjanes-Jo, Molly, 
April, Mal, and Ripley-engaged in a myriad of scouting activities like canoeing, navigating the woods in the dark, and looking on in full scouting regalia as their camp fends off (plays with?) an albino sasquatch ( $L \mathcal{F} \# 4$, cover). Just as in scouting novels, the Lumberjanes' adventures are ones no single real-life scouting troop could ever experience. In the first four issues, the hardcore lady-types battle supernatural foxes, eagles, sea-monsters, and possessed Scouting Lads. They also outwit and befriend hipster sasquatches, master ancient logic riddles, overcome stone guardians in feats of arm-wrestling strength, and take possession of divine implements of war like Artemis' fabled bow. Like fictional female scouts, the Lumberjanes' friendships, camp spirit, and attire never waver nor fail during their trials and travails; like fictional male scouts, the girls manage to avoid receiving any major punishment or injury for breaking camp rules or engaging in outrageously dangerous behavior. Merit badges, like the "Pungeon Master Badge" (awarded for deft punning to April in Lf \#2, p.7 ) and the "Everything under the Sum Badge" (awarded to Jo for enviable skill in mathematics,), are freely awarded; every issue is thematically linked to a badge. Even Molly's outfit, with its living (?!) raccoon hat calls to mind frontier representations of Daniel Boone, cutting his way westward through the Kentucky wilderness. Through their strenuous activity, the scouts gain a deeper understanding of their own relationships and the particulars of the world, both natural and supernatural.

At the same time as it recounts the familiar tropes of the adventurous scouting novel, Lumberjanes carefully navigates around the more problematic content these novels propagated in their earliest iterations. Specifically, Lumberjanes is dedicated both narratively and structurally to avoiding gender binarism-the belief that there are only two gender identities. Broadly, Lumberjanes disallows biological sex or gender identity any 
significant influence on a person's ability to achieve their goals. The girls run the visual gamut of possible gender expressions, from the exceedingly androgynous (Ripley, ostensibly the youngest) to nonbinary (Mal, who half-shaves her head; Jo, who is transitioning) to the outwardly cisgender (April, Molly). Their lack of commonly-worn uniform, unheard of in real-world scouting, emphasizes the Lumberjanes' difference from one another. This allegiance to visual differentiation calls to mind the individualism of boys' scouting novels while destabilizing the misconception that women are naturally more communal-more uniform-than men. In scouting novels, boys tend to come from a wide array of economic backgrounds and, though often white, are often portrayed as individual components of a team. Girl scouts, on the other hand, tend to be interchangeable; their power is as a mob, not a collection of individually-empowered teammates. In Lumberjanes, this expectation is inverted: the Scouting Lads appear uniform, undifferentiated, and domestic.

Beyond visual cues, Lumberjanes resists narrative expectation that girls prefer domestic spaces and boys prefer to be outdoors in the wild. Rather, gender differences are ablated, as Janes and Lads take part in a variety of tasks, domestic, rational, or pioneering, with aplomb. Many of the girls demonstrate the "feminine" traits of domesticity for which Girl Scouts in scouting fiction are renowned. April keeps a flawlessly detailed diary and is always equipped with the powerful but practical Scrunchie ( $L F \# 1)$, while all the girls prove adept at the tried-and-true domestic camp activity of friendship-bracelet weaving ( $L \mathcal{F} \# 5)$. At the same time, their skills extend well into the outdoor fundamentals that were once limited to boys' scouting novels. Roanoke Cabin scout-leader Jen is an adept student of the natural world, with peerless plant and animal recognition (by proper Latin nomenclature, Lf \#4) undergirded with important anthropological uses of the flora and 
fauna she identifies. Her mastery of the night sky $(L \mathcal{Z} \#)$ and its secrets is ultimately what allows the Lumberjanes to save their little corner of the woods from certain domination by the warring divinities, Diana and Apollo ( $L F \# 8)$. Molly, the quiet one, handles bows and arrows as nimbly as she can rearrange sentences into anagrams, both skills that end up saving the Janes' lives ( $L \mathcal{F} \# 6$ and \#8). Mal is a battlefield tactician of some renown with a rocket

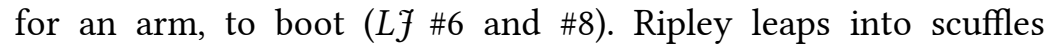
both headlong and footlong, and ultimately channels the divine privilege over which Artemis and Apollo fight (which, of course, she wisely disperses into the universe to prevent its misuse, $L f$ \#2 and \#8). Even the outwardly "girly" April, red of hair and pink of shorts, has a tomboy streak: when Jo aptly comments that the pair are caught in a whitewater current, April triumphantly raises her canoe paddle overhead, saying, "YEAH WE ARE!" (LF $\# 2$, p. 10). It is her arm-wrestling prowess ("It all comes down to leverage," $L \mathcal{f} \# 3$, p.9) that aids the group in defeating an ancient, musclebound stone guardian. Finally, in a scene reminiscent of the "name of God" pit puzzle in Indiana fones and the Last Crusade, Jo's knack for mathematics-recognizing the Fibonacci sequence in a series of seemingly random numbers and remembering it to 233 ( $L F \# 3$, p. 18-19) helps the girls navigate the correct path across the bottomless pit. Perhaps the most gender fluid of them all is Rosie, director of the camp. Styled as a flannel-clad Rosie the Riveter, Camp Director Rosie is an apt homemaker, offering the ladies hot chocolate after a late night romp, as well as an accomplished woodcarver and, apparently, supernaturalist ( $L \mathcal{F} \# 1$, 6 , and 8). Interested in carving wood with any variety of bladed implements from hatchet to penknife and fond of woodland creatures, taxidermied or otherwise, Rosie is the quintessential Lumberjane: a mix of domestic gentleness and rustic tenacity. Her approach is, by turns, motherly and gruff: she (perhaps knowingly) 
gives the girls a long leash on which to explore and solve the mysteries of the woods around camp even as she offers Jen tough encouragement by pretending not to know the troop leader's name or care about her troop's misconduct ( $L \mathcal{f} \# 1,6$, and 8 ). Jen, the constant pushover, gets angrier about this as the series goes on until Rosie reveals that she had faith in Jen's leadership all along (LJ \#8, p.23).

Conversely, boys in Lumberjanes show a true knack for domesticity and nurturing. When Mal is rendered unconscious and not breathing due to water inhalation, the girls panic and don't know what to do. Molly flails her hands, cries, and is told to blow into Mal "like she's a balloon" before ineffectually kissing her. Quick-thinking Ripley saves the day by leaping feet-first onto Mal's diaphragm ( $L \mathcal{F} \# 2$, p. 17). The boys, on the other hand, are apt nurses: they treat the Lumberjanes' poison ivy rashes with skin ointment, attentively serve their guests fresh cookies and hot tea, and keep an impossibly clean cabin ( $L \mathcal{F} \# 4$, p. 8 and 11$)$. Jen gapes at the scene-her idea of perfect campers!-in which domesticity reigns supreme. It stands in stark contrast to the Lumberjanes' filthy cabin and the girls' poor manners. That the lads are so "orderly and obedient," the hallmarks of the perfectly socialized scouting novel lady, therefore reinforces how far from that sexist ideal the Lumberjanes are $(L \mathcal{f} \# 4$, p. 7$)$. Unfortunately, the Lads are revealed to be feral boys when they turn into werewolves shortly thereafter (LF\#4, p. 18). ${ }^{7}$

At this point, it would be easy to say that Lumberjanes merely inverts traditional gender roles, making girls "tomboys" and boys "dandies." In a work that seeks to unsettle traditional gender norms, simple inversion is problematic because the work (perhaps

7. For more on the American trope of the quasi-feral boy-child, see Kenneth B. Kidd, Making American Boys: Boyology and the Feral Tale, Minneapolis, MN: University of Minnesota Press, 2004. 
unwittingly) makes more real the very gender roles it seeks to unsettle by perpetuating the use of binary gender categories. A work that unquestioningly inverts traditional binary gender may actually strengthen the credibility of claims that some skills are inherently masculine or feminine, and that any non-normative gender expression is merely play-acting. The fear of women and men "playing at" gender informs Luther Gulick's concerns that allowing women access to knowledge and experiences once reserved for men would upset the fragile balance of the world. For, if women and men can so easily "enact" gender, how can it be inherent or essential? Judith Butler, philosopher and critical theorist, is a pioneer in queer studies, a branch of cultural studies that seeks to destabilize, among other things, the intertwined notions that gender is binary, intrinsic, and determined solely by biological sex. Instead, queer theorists like Butler suggest that gender is performative, derived from a myriad of cultural norms and social expectations. For queer theorists, genders are not inherent or instinctual; instead, they are formed by a pastiche of actions that have been deemed appropriate to that gender. Thus, it is not enough to merely say that the genders are inverted, as the statement reinforces the fictional intrinsic nature of gender. In order to truly disturb normative ideas of gender, a work must expose binary and incommensurate gender roles, as Judith Butler does, revealing them as "cultural fictions" that are perpetuated by "tacit collective agreement to perform, produce, and sustain discrete and polar genders" (179). Put another way, a work must demonstrate that gender roles, traditional or not, are all cultural fictions. Lumberjanes does not invert traditional gender roles; rather, it shows that the supposedly incommensurate spheres of masculinity and femininity are deeply interwoven. The Lumberjanes' mastery in the sciences and the martial arts does not impede their ability to relate to one another and build strong 
homosocial relationships. By the same token, the girls do not demonstrate an innate connection to domesticity, as evidenced by their poor caregiving skills ( $L \mathcal{f} \# 2$, p. 17 and \#3, p. 15). In fact, the girls' lack of domestic instincts is made a campy joke at the height of narrative tension. Jo has been turned to stone by an ancient curse. Through her logical anagramming skills, Molly discovers that the cure is the power of friendship ( $L \mathcal{F} \# 8, \mathrm{p}$. 11). The girls group hug Jo, heal her, and Mal metanarratively comments that she "can't believe that actually worked. 'The Power of Friendship?' Is this place for real?" (13). Even the feral boys, ostensibly a symbol of innate masculine animalism, are ultimately severed from the instinctual notion of feral boyhood. In order to escape the boys, scoutmaster Jen spills food all over their cabin, causing them to immediately halt pursuit to clean up the mess ( $L F \# 4,19)$. Lumberjanes ultimately shows that such differentiations as male versus female are trivial and imposed-not essential.

This dismissal of binary gendering extends to Lumberjanes' narrative core via sibling rivalries. Sibling rivalries between cisgender males and cisgender females (both mundane and divine $)^{8}$ dramatize the polarizing effects of binary gender constructions. A camper with the Lumberjanes, Diane, is actually Artemis in disguise and reveals that she is locked in a struggle with her brother, Apollo, for control of supreme deific power over the universe. Diane/Artemis is a paragon of modern femininity: trendy, a self-styled "mean girl," too cool for camp and too aloof to participate in weaving friendship bracelets, learning astronomy, or the camp-wide game of capture the flag. When the Lumberjanes

8. Though it is not entirely clear if the namesakes of the Scouting Lads' and Lumberjanes' camps are related, the similarly lengthy pseudo-Victorian names and shared surnames suggest that Mr. Theodore Tarquin Reginald Lancelot Herman Crumpet's Camp for Boys and Miss Quinzella Thiskwin Penniquiquill Thistle Crumpet's Camp for Hardcore Lady Types are the result of sibling rivalry. They also hearken nostalgically back to a romanticized British history of genteel Imperial conquest. 
believe they have cracked her shell, she initially appears nurturing and caring, but it is quickly revealed to be a ruse to get her to the prize. Her presence alone begins to inspire catty in-fighting between close friends Jo and April. The "Camp Director," actually Apollo in disguise, is a caricature of frontier masculinity: he is tall, dark, handsome, and clothed in dirty paramilitary garb. He loudly admonishes his charges, the Scouting Lads, brandishes his hatchet, calls their use of teakettles "pathetic" ( $L F \# 4$, p. 10), and gives the only appropriate response to girls in the cabin: "ew" (10). Real men, after all, do not bake cookies and make tea: as Apollo says, "cookies are for the weak. Real men should be splitting wood and smoking pipes" before stomping off to "catch a fish by wrestling it away from a bear" (10). These statements are reminiscent of the kind of hard-edged, pseudo-military masculinity hinted at by Roosevelt and the scouting movement. Put simply, Artemis and Apollo are caricatures of stereotypical femininity and masculinity. As much as Artemis and Apollo signify traditional gender difference, they also symbolize the inadequacy of gender polarity to describe modern identity, and their casting as irredeemable villains reinforces that they are untenable subject positions: nobody can live up to their expectations. Neither seems a strong candidate for ultimate deific controller of existence: through equivocation or duress, each has misled their charges, misrepresented their roles as leaders, and (most importantly to the campers) cheated in the contest for control of all creation. Faced with a seeming Gordian knot of who to endorse, the Lumberjanes refuse to follow precut paths; they make their own way. Instead of allowing one of the siblings to take control of Zeus' supreme power, the Mal hurls Ripley into the path of the power-granting lightning bolt. She steals the divine gift, taking from gods what was never meant from mortals: the power to re-shape reality $(L f$ \#8, p.18). For the Lumberjanes, that means dispelling the power 
so it can never be used against mortals again; symbolically, Ripley casts aside the outmoded systems-binary gender norms, the conservative tradition of scouting novels, Imperialist messages of frontiersmanship and conquest-in favor of a new system, yet to be seen.

The use of Artemis and Apollo here is also an important opportunity for Lumberjanes to distance itself from the imperialist, racist stereotypes upon which many scouting trials and rituals were based. Jennifer Helgren, writing on the appropriation of Native American rituals for white consumption by Camp Fire Girls, explains that Camp Fire Girls co-owner Charlotte Vetter Gulick "intend[ed] to carry out, so far as possible, the ideal out-ofdoor Indian life" ("Camp Gulick on Lake Sebago"). For the Gulicks, the way to return lost (fictional) natural domesticity to Camp Fire Girls was via "making Indian jewelry and costumes, performing Indian dance and music, learning Indian myths and folklore, and using the Indian form of government" (Helgren 333). Racist, "noble savage" imagery and practice profoundly influenced scouting organizations, from the use of seemingly Native American naming conventions for camps and cabins to pseudo-native decorations on fringed leather dresses and eagle-feather headdresses (Helgren 334). Only a few decades after the cessation of governmentsanctioned violence against Native Americans, the appropriation of these forms allowed white Americans to redefine their bloodspattered past: Shari Huhndorf writes that the "imperialist nostalgia" for the noble savage symbol "veils the terrible violence marking the nation's origins" (75-6). Helgren adds that these appropriations conveniently "essentialized gender and created racial hierarchies within the nation" (334). The staking out of once-held ideological territory became the new frontier of AngloAmerican conquest in the 20th century; as more and more white girls were called to "go native" in scouting organizations, true 
native experience eroded. But the girls had recourse to resistance even then; forced to "perform an idea of Indianness within a white institution not of their making," Camp Fire Girls were subversively empowered to "[articulate] their own identities as modern girls" (334). Helgren argues that, "Sometimes contesting and sometimes accommodating prevailing gender and racial hierarchies," (334) Camp Fire Girls, both white and indigenous, were empowered to articulate hybrid cultural practices. In a similar way, Lumberjanes resists the purely indoctrinational values of the imperial discourses that brought about the scouting movement, substitution hybridity in place of essentialism. The use of the twins Apollo and Artemis replaces traditional "noble savage" mysticism; instead of appropriating the mythology of a conquered victim, Lumberjanes rewrites Hellenic myth, making the poetic and intelligent Apollo a gruff buffoon and the huntress of the hills Artemis a mean girl with no outdoor sense. ${ }^{9}$ Instead of hiding the upper-crust origins of scouting behind pseudo-native naming, Lumberjanes foregrounds its roots in high-society England, as suggested by the long, Victorian-esque namesakes of its camps. The lone use of a native name-Roanoke, the Lumberjanes' cabin-calls to mind beneficial multicultural blending, hybridization by another name. In popular conception, Roanoke colony was "lost" when settlers intermingled with nearby tribes of Native Americans; according to historian Giles Milton, evidence found at the former colony site supports this popular belief (265-266), while, according to Glenn Ellen Starr Stilling, DNA testing has shown significant intermixing in the Lumbee tribe near that area ("Lumbee Origins"). Even the opportunity given

9. As a Bakhtinian, I understand this revision as one with "a glance to the side"-the reader is expected to know the myth and laugh at the recasting of these mythic figures, not take it at face value. This kind of knowing reading suggests deeper engagement with the myth than scouting organizations would have done in appropriating Native American figures like the Crow. 
to (appropriated by) Ripley functions as a hybridizing measure: the idea of "godliness" the Lumberjanes have come to recognize is not an institution of their own making, but instead has been shaped by Artemis and Apollo's actions throughout the course of the narrative. They are not native to the practices therein, so when Ripley chooses to utilize the power and dictates her newly-divine will, she subverts the dominant paradigms controlling masculinity, femininity, scouting, and even relations between mortals and immortals. ${ }^{10}$ Her choices range from silly to wise, but she ultimately resolves the sibling rivalry by destroying the divine gift (Lf \#8, p. 21). Perhaps most importantly, the Lumberjanes represent diversity in race, economic background, gender identity, and sexual preference even as their adventures suggest an inward turn for exploration. Rather than colonizing the woods where they adventure, taking over and making their will the law of the land, the Lumberjanes attempt to live harmoniously within it; what few creatures they harm are mythical creatures put there by Artemis and Apollo to deter the other sibling. Even when they traverse the cave of trials, the girls make friends with the guardians, rather than destroying them. When faced with opposition, such as the Scouting Lads-as-werewolves or a band of magical raptors (the dinosaur, not the bird of prey), the girls find a way to band together with the opposition. Ripley tames a raptor and rides it into battle at the end of volume two, and the Lads are saved with only minor injuries and the promise to team up again. The recurring message in Lumberjanes is "friendship to the max", but it may be fruitfully revised as "mutually beneficial" and "nonablative of individual difference" friendship to the max.

10. Ripley's appearance in this section of book eight alludes to the shonen manga-comic books written specifically for teenage boys-Dragon Ball and Dragon Ball $Z$. 
The history of the scouting movement retold through the scouting novel has been, as Inness maintains, primarily "saccharine and uncritical" (Inness 98), failing to recognize the problematic gender constructions these movements outwardly perpetuated. However, critics have begun to note progressive undercurrents in some of the literature these groups produced. Rebekah E. Revzin and Laureen Tedesco challenge the traditional notion that all scouting materials reinforced early 20th century gender norms. Revzin argues that an ideological reading of Girl Scout handbooks and guides from the 1920s reveals that "[T]he Girl Scout organization (1) promoted feminist ideology to young girls in the early 1900s, (2) expected a woman's sphere to be restricted to the realm of children, religion, and the home, and (3) encouraged women to display independence either surreptitiously or overtly" (261). She admits that much of the content of official Girl Scout literature "promoted a traditional ideology of female domesticity, but she notes a "significant amount of material that challenges the more conventional feminine doctrine of the time" (268). In addition to traditionally feminine domesticity, Revzin reveals that the Girl Scouting handbooks espoused traditionally masculine virtues as well: to be "strong, educated, self-reliant, and goal-oriented, rather than timid, meek, subservient, and helpless" (268). As Mary Logan Rothschild puts it, "Girl Scouting emphasized both traditional feminine roles and a kind of practical feminism. At different times, one of these emphases has waxed and the other has waned, but neither has ever vanished from the program" (316). Tedesco maintains that such outwardly subversive cultural work was overlooked because "the Girl Scout program tried to solve some problems popularly believed to be immigrant problems-sanitation issues, ignorance about democratic processes, health deficiencies, inadequate maternal knowledge" (362). By visibly dedicating themselves as "home missionaries" 
(Tedesco 350), Tedesco argues, the Girl Scouts provided themselves with cultural cover. Appearing to solve issues that "resonated with the middle class, who had the leisure, money, and education to resolve them in their own lives" (362), Girl Scouts more likely "addressed those matters among the organizing class, not the class perceived as needing instruction" (362). And when "Progressive era interest in helping or besting the immigrant" ended, the Girl Scouts turned their collective eye to international peace, the next conservative talking point on a long list. By keeping questions of American conservation close to the surface, the Girl Scouts enjoyed "a measure of outdoor independence and soldierly role-play" (362). By the same token, Boy Scouting and boys' camps may have focused on traditional, if mythological, markers of manliness, but a primary component of maintaining paramilitary orderliness, cleanliness, and hygiene lies squarely in the domestic sphere. Just as Gulick feared, allowing Girl Scouts access to the "masculine arts" produced an androgynous blurring of differences between Boy and Girl Scouts.

Lumberjanes is not a single piece of resistance against gender binarism in an otherwise hopeless quagmire. Other revisions of the scouting novel, such as the aforementioned Moonrise Kingdom and Camp Weedonwatcha have made great strides in recovering this lost, once-popular genre from obscurity. ${ }^{11}$ Even scouting organizations have taken note and begun to change, albeit slowly. Scouting novels and the conservative organizations that inspired them, especially the Camp Fire Girls, seem inherently flawed

11. These works are complex enough that they deserve a much longer treatment than I could give them here. In particular, Wes Anderson's ambivalent treatment of the "heteronormative first love" story alongside the dissolution of parental marriage is provocative; Katie Rice's webcomic is true to children's literary forms in that absolutely no adults are present, and the resulting wide-open space affords personal and interpersonal exploration that powerfully counteracts the highly-structured form of scouting in which many contemporary children participate. 
creations wedded to the idea of preserving binary gender difference. But just as the novels can and have been rehabilitated and revised, so too can organizations. In 1975, as the Boy Scouts and Girl Scouts remained predominantly single-sex, Camp Fire announced an internal vote to become co-educational. Though the Boy Scouts symbolically opened their organization to girls through the Venture program and the Girl Scouts maintained that it had always been a feminist organization, Camp Fire's coeducational approach represents the most progressive take on scouting precisely because it eschews gender difference. Indeed, gender presentation and sexual orientation has been a hot topic in scouting during the 21st century: the Girl Scouts made their inclusive stance public in 2011, though they noted it had always been their position to allow lesbian-gay-bisexual-transgender girls into the fold, while the Boy Scouts allowed gay leadership and members only in 2013. Regardless of this openness, the dedication by the Boy and Girl Scouts to, apparently, preserve the incommensurability of boyhood and girlhood is troubling. Like Lumberjanes' reiteration of the girl scouting narrative, which revises the early form by removing its problematic representation of gender as an exclusive binary, Camp Fire seems to be taking steps toward dismantling gender binarism in youth groups. Even as Lumberjanes takes on issues of inequality in comics artisanship and publishing, it also participates in a wide-ranging, multimodal cultural reconsideration of youth and gender" "to make the world a better place, for Lumberjane scouts and for everyone else".

12. In addition to the scouting films and comics I listed at the beginning of this article, see Conn Iggulden and Hal Iggulden, The Dangerous Book for Boys, New York: William Morrow, 2007, and Andrea J. Buchanan and Miriam Peskowitz, The Daring Book for Girls, New York: William Morrow, 2007. The books are guidebooks in the style of early Boy and Girl Scout handbooks. 


\section{Works Cited}

Berry, Alison. "Review: Lumberjanes \#1." Comicosity. Published Apr. 14, 2014. Web. 12 December 2015.

Buckler, Helen, Mary F. Fiedler, and Marth F. Allen. Wo-He-Lo: The Story of Camp Fire Girls 1910-1960. New York: Holt, 1961. Print. Butler, Judith. Gender Trouble: Feminism and the Subversion of Identity. New York: Routledge, 1990. Print.

Carpan, Carolyn. Sisters, Schoolgirls, and Sleuths: Girls' Series Books in America. Lanham, MD: The Scarecrow Press, 2009. Print.

Garis, Lilian. The Girl Scout Pioneers or Winning the First B.C. New York: Cupples, 1920. Print.

Gulick, Charlotte V. "Camp Gulick on Lake Sebago." Camp Fire USA. Kansas City, MO: CFUSA, 1910.

Helgren, Jennifer. "Native American and White Camp Fire Girls Enact Modern Girlhood, 1910- 39.” American Quarterly 66.2 (June 2014): 333-360. Print. http://dx.doi.org/10.1353/ aq. 2014.0031

Hoover, Latharo. The Camp-Fire Boys in the Philippines. New York: Burt, 1930. Print.

Huhndorf, Shari. Going Native: Indians in the American Cultural Imagination (Ithaca, NY: Cornell UP, 2001).

Inness, Sherrie A. "Girl Scouts, Camp Fire Girls, and Woodcraft Girls: The Ideology of Girls' Scouting Novels, 1910-1935.” Nancy Drew and Company: Culture, Gender, and Girls' Series. Ed. Sherrie A. Inness. Bowling Green, OH: Bowling Green State University Popular Press, 1997: 89-100. Print.

Levy, Harold P. Building a Popular Movement: A Case Study of the Public Relations of the Boy Scouts of America. New York: Russell Sage Foundation, 1944. Print. 
Miller, Susan A. Growing Girls: The Natural Origins of Girls' Organizations in America. New Brunswick: Rutgers UP, 2007. Print.

Peters, Sarah L. "'Moon Lake' and the American Summer Camp Movement." Eudora Welty Review 6 (2014): 55-67. Print. http://dx.doi.org/10.1353/ewr.2014.0014

Revzin, Rebekah E. "American Girlhood in the Early Twentieth Century: The Ideology of Girl Scout Literature, 1913-1930." The Library Quarterly: Information, Community, Policy 68.3 (Jul 1998): 261-275. Print. http://dx.doi.org/10.1086/602982

Roosevelt, Theodore. "The Strenuous Life." Hamilton Club, Chicago IL, 10 April 1899. Full text available: http://www.bartleby.com/58/1.html. Web.

Rothschild, Mary Logan. "Girl Scouts." Girl Culture: Studying Girl Culture: A Reader's Guide. Eds. Claudia Mitchell and Jacqueline Reid-Walsh. Westport, CT: Greenwood Publishing, 2007: 314-317. Print.

Singleton, Ellen. "Camps and Tramps: Civilization, Culture, and the Use of Leisure in the Early Twentieth-Century Outdoor Adventure Series Books for Girls and Boys.” Leisure/Loisir 29.1 (2005): 49-70. Web. 27 December 2015.

Tedesco, Laureen. "A Nostalgia for Home: Daring and Domesticity in Girl Scouting and Girls' Fiction, 1913-1933," Dissertation: Texas A\&M, 1999. Web. 19 December 2015.

-. "Progressive Era Girl Scouts and the Immigrant: Scouting for Girls (1920) as a Handbook for American Girlhood." Children's Literature Association Quarterly 31.4 (2006): 346-368. Print. http://dx.doi.org/10.1353/chq.2007.0011

Watters, Shannon, Grace Ellis and Noelle Stevenson. Lumberjanes Volume 1: Beware the Kitten Holy. Collects issues 1-4. Los Angeles: Boom! Studios, 2014. Print. 
90 Good Grief! Children and Comics

-. Lumberjanes Volume 2: Friendship to the Max! Collects issues 5-8. Los Angeles: Boom! Studios, 2015. Print.

-. Lumberjanes Volume 3: A Terrible Plan. Collects issues 9-12. Los Angeles: Boom! Studios, 2016. Print. 


\title{
5. The Great
}

\section{American Graphic}

\author{
Novel
}

\section{JEFF SMITH'S BONE AND ITS INFLUENCES}

\author{
Annette Wannamaker
}

Comics scholar Joseph Michael Sommers writes that "Comic books are American mythology" ("On the American Comic Book" xxiii). While many would assume this American pop mythos is inhabited exclusively by a pantheon of costumed super heroes like Batman, Wonder Woman, and Superboy keeping the world's Gothams, Paradise Islands, and Smallvilles safe from crime, Jeff Smith's popular fantasy comic Bone also participates in a version of myth making that interacts with its American contexts in profound ways. Although Smith's work of fantasy, on the surface, appears to be far removed from American cultural and literary traditions, this epic 1,344-page graphic novel is modeled, in part, after great American novels like Herman Melville's Moby-Dick and Mark 
Twain's The Adventures of Huckleberry Finn. Indeed, Smith has said in interviews that he was inspired by both of these classics. For example, he explains, "If we are dignifying issues as chapters, Huckleberry Finn was perfect for the overall structure. It starts like a boy's adventure story (which I enjoy anyway) like Tom Sawyer [...] but goes on to get darker and more sophisticated as the story progresses" (qtd. in Williams 54). Bone is a work that combines the narrative structures of Huckleberry Finn with motifs from Moby-Dick and then intertwines these with visual nods to famous American cartoonists and multiple references to American popular culture, and those are just the surface ways in which the story grapples with its American roots. Even though the graphic novel draws upon older fantasy tropes and aspects of the heroic epic, it remixes these with story structures, themes, and artistic styles central to literary and popular texts created in the United States to such an extent that it reinvents older forms in order to create a specifically American adventure story. In this chapter, I examine Bone's influences to demonstrate that it is a work firmly grounded in styles created by earlier American writers, cartoonists, and animators, which provides the work with a historical and cultural context that situates Bone within a larger literary tradition and can provide deeper understandings of its meaning and significance.

One obvious way in which the series invites readers to consider its American roots is in its references to the work of Herman Melville, a point that Jennifer Hughes and Philip Nel have thoroughly explored. They argue that readers do not need to have read Moby-Dick in order to understand Bone, but that readers who have read or who have some degree of familiarity with Melville's masterpiece will gain an "understanding of some of Bone's deeper meanings" (130). The main character, Fone Bone, carries a copy of the novel with him wherever he goes and frequently reads 
aloud from it, much to the dismay of other characters: "It's my favorite book! I've read it three times!" he explains to Thorn, adding, "Every time I try to tell people about Moby Dick their eyes glaze over!" (70). The novel also shapes some of Fone Bone's prophetic dreams, where he imagines himself, for example, as Ishmael afloat in an ocean clinging to a casket (891-2). Hughes and Nel explain that, because Bone alludes so frequently to MobyDick, it touches on similar themes as Melville's great American novel: They argue that "both offer a meditation on power, nation, and citizenship" and that both books ask readers to consider the morality of characters' decisions and actions in the context of a capitalistic society (118).

For example, the three Bone cousins are depicted "at varying points on the moral spectrum" (Hughes and Nel 119). Phoney Bone is pathologically driven to make money, partially because he feels obligated to support his family and partially because he is single-mindedly greedy (much like Uncle Scrooge McDuck); the kind and generous Fone Bone is torn between his loyalty to his cousins and his significant, spiritual connection to Thorn; and the gullible, goofy, and sometimes amoral Smiley Bone adopts a Rat Creature baby (which he names Bartleby, in a nod to a short story by the author of Moby-Dick) despite the protestations of his cousins and the residents of The Valley that he is harboring the enemy. Through the experiences and actions of the Bone cousins especially Phoney's multiple get-rich-quick schemes - Bone raises questions that have long been central to American history, culture, and literature, especially about the ethics of the free marketplace.

Cued by Hughes and Nel, we can look more deeply at ways that Smith's story explores issues dear to an American identity, specifically capitalism, and we can quickly discover that this theme extends beyond the most obvious character. Phoney's get- 
rich-quick schemes are comic in their excessiveness, but they also ask readers to think critically about the Bone cousins' moral choices. After all, Phoney's schemes are never victimless plots, they are fueled by greed, and they often have the potential to create very real suffering. The narrative depicts several disagreements between Phoney and Fone Bone, each of which dramatizes the implications of Phoney's dubious entrepreneurial enterprises by highlighting the differing ethical stances of the two cousins:

Phoney: So I got us run out of Boneville and a lynch mob chased us for two weeks! Jeez! One little mistake, and I gotta pay for it the rest of my life?!

Fone: Maybe you'll think twice next time you build an orphanage on a hazardous waste landfill!!

Phoney: What is wrong with that?! That's two community services rolled into one! It was th' ultimate tax shelter!

Fone: You never learn, do you? (89-90)

Significantly, Phoney never does learn. He rigs a race so that he can collect bets from the people of Barrelhaven, his attempts to swindle the same gullible townspeople out of all their savings a second time almost result in the death of a dragon, he uses the distractions of a battle to steal the kingdom's treasury while its capital is under siege, and up until the very end of the narrative he even tries to return to Boneville with the kingdom's treasury, which Queen Thorn will need to repair and run the kingdom. It's no wonder that Fone imagines Phoney as the single-minded and destructive Captain Ahab in his Moby-Dick inspired dreams.

It is important, though, to think of Bone's American roots as grappling with traditions that are more subtle. Much of Bone's 
success is also due to Smith's distinct style of storytelling and cartooning and to the lovable characters he has created. As the story of Bone begins, we gradually get to know the three Bone cousins, whom Andrew. D. Arnold describes as being part of "a peculiar-looking, diminutive race." He continues, explaining, "They are pure cartoon - cute and pantsless, with four fingers on each hand and smooth, rounded, sexless bodies. At first their personalities are similarly simple. Fone, the dreamy one, must constantly get out of the scrapes created by Phoney, the avaricious schemer, and Smiley, a goofball comic foil whose tongue hangs out like a friendly dog's" (Arnold). The Bone cousins are, as Arnold points out, "peculiar-looking" creatures that are not quite human or animal and who have bodies that can bounce, contort, and withstand physical abuse in ways akin to many of the animated characters that populate American children's cartoons.

That visual style both complicates the story's relationship with Melville and deepens its American roots. Unlike Captain Ahab, whose quest for the white whale tragically kills him and almost all of his crew, Phoney, his comrades, and his potential victims-all of them more cartoonish than Melville's creations in both their appearance and their resistance to abuse-are not harmed when each of his plans repeatedly backfires (or is comically subverted by his cousins). This difference in characterization and in consequence is due to Smith's visual style and his mixing of disparate genres, specifically the serious, philosophical, and highbrow Moby-Dick with silly, lowbrow, physical comedy culled from American popular culture of the midTwentieth Century. Comics scholar Scott McCloud explains that "Virtually any real strong work of fiction, I think, has a variety of tones to it. It represents the variety of the tones of life. So, to me, it's more an aberration not to have that mixture of humor and gravity that Jeff does so well” (qtd. in Mills). Smith's flawed, 
funny and sometimes conflicted characters are just as inspired by his childhood love of popular American comedy (Donald Duck, Bugs Bunny, Mad Magazine, the Three Stooges, the Marx Brothers and other comic book, cartoon, and television regulars) as they are by classic American literature.

Carl Barks's legendary run on that great American export, comics featuring Donald Duck, for example, inspired Smith's work in multiple ways. Donald Duck and Uncle Scrooge McDuck live in a town called Duckburg, and the Bone cousins hail from a place called Boneville. Uncle Scrooge is the richest duck in Duckburg, just as Phoney is the richest Bone in Boneville. But the similarities don't end there. For instance, in one 1952 Donald Duck comic (Walt Disney's Comics and Stories, No. 145), Uncle Scrooge goes to great lengths to collect a dollar owed to him by a character named "Rockjaw Bumrisk," an anthropomorphized and brutish bulldog (Spiegelman and Mouly 135). A major character in Bone is called "rock jaw." The giant, amoral, bully of a mountain lion is actually named "Roque Ja" but, much to the lion's disgruntlement, Fone Bone and other characters mispronounce his name as "rock jaw": "My name is Roque Ja, Not rock jaw," the lion says to a captive Fone Bone, "and you needn't worry about where my sympathies lie" (637). The direct allusion to a Donald Duck character adds a humorous element to an otherwise intimidating predator.

Another significant connection to Barks's Donald Duck and Uncle Scrooge comics is the way in which Phoney refuses to hand over a dollar, even in the middle of the desert. Indeed, his comedic quest to hold onto a dollar frames the entire narrative of Bone: In the opening scene Smiley Bone finds a map and teases Phoney Bone by holding it out of his reach:

Phoney: I'm saved! Give it to me! Smiley: Gimme a dollar first. 


\section{Phoney: What?}

Fone Bone: Go on, Phoney! Give him a dollar!

Phoney: What!?

Fone Bone: We're lost in the middle of the desert! Give him a dollar!

Phoney: All right, all right ... Hey! What is this? This looks like it was drawn by a five year old! This thing is worthless!

Smiley: It's worth a dollar! (19-20)

This opening scene is echoed on the very last page of the complete edition as the Bone cousins ride home to Boneville on an oxdrawn cart. Phoney has tried to steal the kingdom's treasure, but his cousins and Gran'ma Ben empty the treasure chest and fill it with sandwiches, leaving him with a small handful of gold coins. A defeated Phoney says, "Sigh. I don't even like hard, stuffed breadthingies," and Smiley answers, "Better learn to like 'em. They're the only food on board." When Phoney asks for one, Smiley says, "Gimme a gold coin first," to which Phoney responds, "What?!" Fone Bone then utters the last line of the graphic novel: "Oh, give him a gold coin, Phoney. We're out in the middle of the desert" (1332).

Phoney, like Uncle Scrooge, is a limited and static character. His experiences in The Valley don't significantly change him, and he often functions more as a foil for Fone Bone than as a fully realized character. Barks's characterization of his creation, Uncle Scrooge McDuck, could easily apply to Phoney Bone: "he did always have one characteristic, his desire for money. That was the first thought that would come into his head whenever he was in a dangerous situation, how to save his money rather than himself" (qtd. in Barrier, 191). Significantly, because they are not fully developed, three-dimensional characters, both Phoney Bone 
and Uncle Scrooge can sometimes function in ways that are allegorical and can be used for social commentary. One example of this connection between the characters is in a 1948 comic by Barks titled "Tralla La” (Walt Disney's Uncle Scrooge, No. 6), which begins with the wealthy Scrooge stressed out by having to manage his billions. He searches for a land where he can live free of stress, "where there is no money, and wealth means nothing" (Spiegelman and Mouly 254). He finds this mythical place in a remote valley in India, which a local describes simply as "the valley," "a round, deep valley, ringed by very high mountains [...] like a beautiful green bowl" (257). The depictions of the Indian inhabitants of Tralla La are deeply racist and imperialistic: the residents of the remote valley are colored bright yellow, are dressed in stereotypical and generic "Asian" clothing, and they are depicted as ignorant natives who are easily enthralled by the bottle caps with which Scrooge litters their valley. They soon turn these bottle caps into currency, trading sheep, pigs, and labor for the "shiny bauble[s]" (265). The people of Tralla La, in their lust for bottle caps, eventually turn on Uncle Scrooge, saying things like, "If this rich old miser doesn't give his bottle caps to-uh-people like me, he's an old meanie!" and "Raise his taxes!" (267). In order to appease the natives, Uncle Scrooge arranges to have a billion bottle caps dumped via airplane on Tralla La, a plan that both backfires and works because he pollutes the valley so badly that he is forced to return to Duckburg. While the political and cultural insights provided by "Tralla La" and Bone are very different (Bone avoids the overt racist and imperialistic assumptions behind the 1948 Scrooge comic), the influence of Barks's work on Smith's is pronounced: The Valley in Bone is isolated by mountain ranges and looks like a "beautiful green bowl" (figure 1), the people who live there barter for goods, and the rural residents are gullible. Smith read a lot of Barks's comics as a child and said, "I always wanted 
Uncle Scrooge to go on a longer adventure" (qtd. in Mills). In many ways, the character of Phoney Bone fulfills this childhood wish.

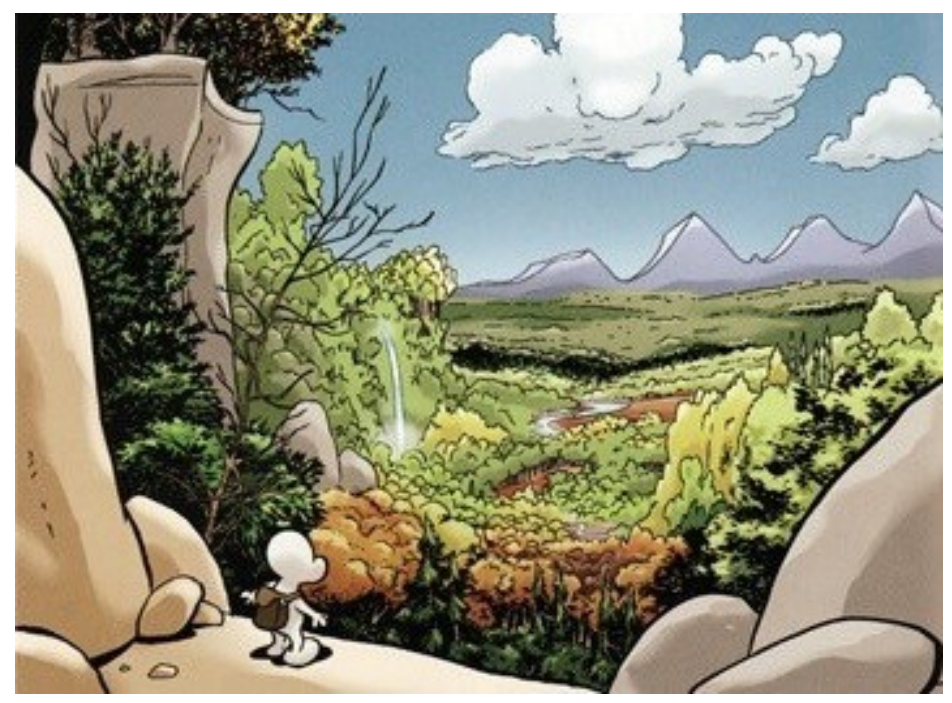

Figure 1: The Barks-style valley. (Smith, Jeff. Bone: Out from Boneville. Columbus, OH: Cartoon Books, 2005. Page 18, panel 1)

Smith calls Barks a "comics genius" because "he knew how to move characters through panels, he knew how to have the characters move and look like they're full of life. You could always tell what the characters were thinking" (qtd. in Mills). The influence of Barks's illustrative style, as well as his characters and story lines, is reflected in Smith's style of cartooning, perhaps because both worked as animators as well as cartoonists. Michael Barrier writes that, as Barks worked transferring animated Disney characters from films into comic books, he figured out how to "adapt characters designed for animation to the printed page" and, ultimately, his characters "were emphatically creatures of print, even though their origins in animation were never in doubt" (Barrier 181). Smith, who ran an animation studio for seven years 
before working on Bone, has said that he was as influenced by animated television cartoons as by printed comic books and comic strips printed in newspapers.

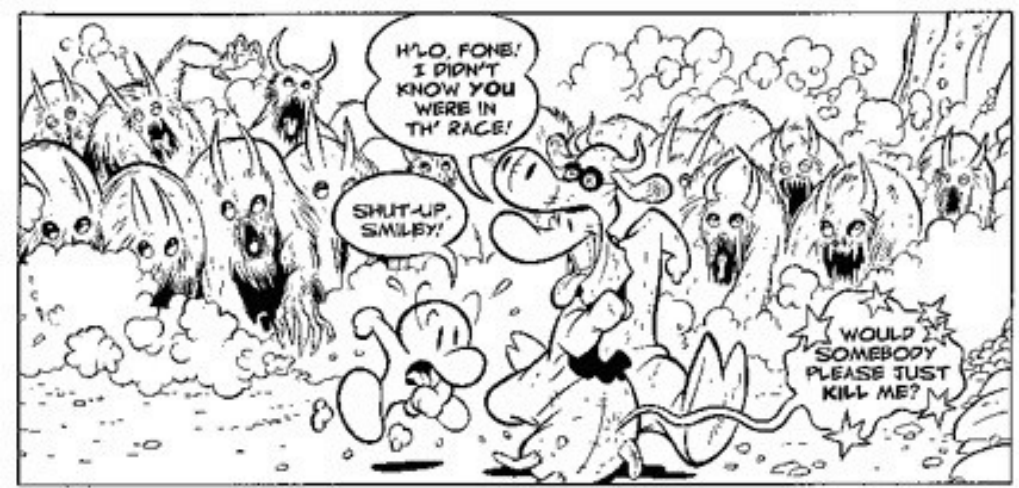

Figure 2: The Bone cousins in the Great Cow Race. Notice the contrasting line work between foreground and background. (Smith, Jeff. Bone: The Complete Cartoon Epic in One Volume. Columbus, OH: Cartoon Books, 2004. Page 231, panel 3.)

Another important childhood influence on Smith was Walt Kelly, the American cartoonist who created the beloved Pogo comic strips. Smith lovingly thanks Kelly for being his "teacher," saying that reading Kelly's collection Prehysterical Pogo convinced him, at the age of nine, that he wanted to become a cartoonist. Smith carefully studied and copied Kelly's illustrations: "I learned to make characters look like they are thinking and speaking with their own unique voice," Smith said of Kelly's influence. "I learned to ink with graceful thicks and thins, to make one line appear to go underneath another" (qtd. in Schutz 17). This technique is used to great effect throughout Bone, especially in larger cinematic scenes depicting detailed scenery or crowds of characters. The climactic ending of the Great Cow Race, for example, depicts the Bone cousins, with Smiley and Phoney wearing the front and back of a 
cow costume, running away from a mob of Rat Creatures (figure 2). In the original black-and-white comic, there are no colors and there is very little shading, factors that make it difficult to convey perspective. In order to distinguish between the rat creatures in the background and the Bone cousins in the foreground, Smith uses heavier and lighter lines of ink to create the illusion of threedimensional space. Carefully placed dust clouds create strategic white space separating the cousins from the army of Rat Creatures on their heels. The result is a scene that is both comic and alarming, depicted in a panel that is a snapshot of one frozen moment in the midst of much chaotic movement.

The Pogo comics, which also featured both slapstick humor and social, political commentary, were populated by a large cast of odd characters who lived in the Okefenokee Swamp, a large swamp in the United States that straddles the border between Georgia and Florida. Like Barks and Smith, Kelly also worked as an animator, an experience that influenced his style of illustration: "Trained as an animation artist at the Walt Disney Studio, Kelly filled Pogo's Okefenokee Swamp with masterfully rendered flora and fauna" (Walker 356-7). Smith also adopted this aspect of Kelly's illustrative style, using Ohio's Hocking Hills State Park as inspiration for the terrain of The Valley. Caswell said, of the scenery depicted in Bone, "Jeff has taken growing up in central Ohio and his love of the Hocking Hills and incorporated that into his narrative in a beautiful way" (qtd. in Mills). Smith's illustrations of the caves, gorges, and waterfalls in the Hocking Hills not only place the fictional Valley in an American setting but also add another layer of visual (and, again, American) allusions to an already rich text.

Even Bone's creation story follows the American ideal of succeeding through spunky individualism, stick-to-itiveness, and creative entrepreneurship. Following in the tradition of the 
American poet Walt Whitman, who self-published Leaves of Grass, which he then continued to write and rewrite and publish and republish for the rest of his career, Smith handwrote, hand drew, and self-published his behemoth of a narrative over a period of 13 years from 1991 to 2004, and he continues to rework it in various formats. He started drawing the Bone characters much, much earlier, when he was a child growing up in central Ohio in the 1960s and 70s, and he has spent much of his lifetime working on Bone. Bits of what would become the Bone narrative were first published in 1982 when Smith penned a comic strip called "Thorn" for the Ohio State University newspaper, The Lantern. A decade later, Smith further developed the story and wrote, drew, printed, marketed, and distributed the first black-and-white issues of the Bone comics on his own. "I wrote out a business plan in 1989, before I started self-publishing Bone," he said in an interview. "You kind of have to, it goes alongside the creative process. If you were making a movie you would have to plan it out completely before it started. Way ahead of the ending I knew how the story was going to conclude" (qtd. in Williams 49).

After a year of being responsible for every aspect of publishing his comic - "I was doing everything myself", he said. "I was packing the boxes and putting them on the UPS truck and I was drawing the comics and I was trying to answer the letters in the letters columns [...] I was starting to screw up" (qtd. in Mills) - Smith became overwhelmed and asked his wife (the initial inspiration for his character Thorn), Vijaya Iyer, to take over the business side of Cartoon Books, the company he created to publish Bone. Cartoon Books has since continued to publish and republish various versions of the Bone narrative. It initially appeared in black-and-white comic books that Smith sent directly to comic book stores. Then these were collected into bound volumes, which were later assembled into the complete, collected, phonebook- 
sized graphic novel. Most recently, colorized volumes have been published and distributed through Scholastic Books to schools, thus helping to create a whole new generation of comics fans. The popularity of Bone, propelled largely through the tenacity of Smith and Iyer, is an indy comic success story one might see romanticized in a Horatio Alger-inspired Hollywood biopic: Ohio kid draws his way to the American Dream!

Hughes and Nel explored the story's explicit references to a great American novel, and I have been arguing that Bone is deeply rooted in even broader American traditions, but I want to close by pointing out that Bone does more than reflect and borrow from other American cultural and literary texts; it also resists and influences them. Despite its literary and artistic complexity, Bone is often ignored or only briefly mentioned in academic textbooks focused on the graphic novel, which devote most of their space to "serious" and "adult" works by the likes of Chris Ware, Art Spiegelman, Marjane Satrapi, Alison Bechdel, and Alan Moore. It is also largely overlooked in collections of academic essays that categorize comics by visual style or by genre. This may be the case because Smith's work is so difficult to categorize: it appeals to both children and adults, it is a strange mix of slapstick comedy and high fantasy, and Smith's illustrative style is both realistic and stylized in the ways it combines cartoon-like characters with lush, detailed backgrounds. Indeed, in an essay that attempts to categorize comic books by genre, Sommers uses the Bone comics as an example of a work that resists classification, explaining that "comics, such as Jeff Smith's ingenious Bone, could easily classify, given a particular audience, under 'adventure comics,' 'fantasy comics,' 'humor comics,' 'comics for children', etc. as Smith's genius and transcendence defies simple classification and stratification" ("Negotiating” 75). 
Smith's genre-defying experimentation is what simultaneously connects Bone to other innovative, independently published graphic novels being created in the 1990s and what distinguishes it from them. Although the comic was originally meant to appeal to adult fans of indy comics, once it was released in bound volumes, it quickly gained a following among children, parents, librarians, and teachers. In their book, Comics: A Global History, 1968 to the Present, Dan Mazur and Alexander Danner argue that Bone's ability to cross generational divides helped to make visible a significant problem in the comics industry of the late twentieth century: there were very few comics being created for children or an all-ages audience, which meant that future generations of readers might not cultivate a love of comic books:

The success of Bone as an all-ages title served to highlight an unexpected problem in the industry: despite people's assumptions about the audience for comic books, most mainstream superheroes were no longer remotely geared to young readers, especially as the 'grim and gritty' aesthetic dominated in the late 1980 s and the 1990s. There was a dearth of material for young readers, leaving a wide opening for Smith's Bone to become a runaway hit for an underserved audience. (231)

While most American comics of the 1980s and 1990s had become "grim and gritty," oftentimes edgy, material aimed at a niche market of adult comics aficionados, Smith tapped into other influences from American culture - classic novels, popular films, television cartoons, newspaper funnies, and commercial animation - to create an all-ages adventure story with a much broader and, perhaps, longer lasting appeal. 
American literature and culture has often reflected anxieties about adulthood: As citizens of a former colony and young nation, American writers long resisted depicting American identity as childish or adolescent. When Bone is situated within this larger historical context, as well as within a comics culture of the late twentieth century that was very invested in distancing itself from childhood, it stands out as a work of literature that both is inspired by and actively resists its influences. The fact that Bone evolved from a comic aimed at adult readers to one marketed directly to child readers marks a significant shift in comics readership in the US. Indeed, in 2005, Scholastic inaugurated Graphix, its highly successful line of graphic novels for children, by publishing colorized versions of the nine Bone volumes. The popularity of the Graphix editions of Bone among children assures that Smith's work will most certainly inspire the next generation of comics artists and writers. In these ways, Bone is not simply a work that was influenced by classic American comics; it has itself become an influential classic, a great American graphic novel.

\section{Works Cited}

Arnold, Andrew. "No Bones about It." Time Magazine. September 17, 2004. Time.com. Web. 2 January 2016.

Barrier, Michael. Funnybooks: The Improbable Glories of the best American Comic Books. Oakland, Calif.: U of California P, 2015. Print.

Hughes, Jennifer A. and Philip Nel. "Re-imagining America: Jeff Smith, Herman Melville, and National Dreamscapes." Journal of Graphic Novels and Comics 4.1 (2013) 117-113. Tandfonline.com. PDF. http://dx.doi.org/10.1080/21504857.2012.718287 
Mazur, Dan and Alexander Danner. Comics: A Global History, 1968 to the Present. London: Thames and Hudson Ltd., 2014. Print. Mills, Ken. Director. The Cartoonist: Jeff Smith, Bone, and the Changing Face of Comics. 2009. DVD.

Schutz, Diana. Ed. The Art of Bone. China: Dark Horse Books, 2007. Print.

Sommers, Joseph Michael. "On the American Comic Book." Critical Insights: The American Comic Book. Ed. Joseph Michael Sommers. Ipswich, Mass.: Salem Press, 2015. Xiii-xxvii. Print.

-. "Negotiating Popular Genres in Comic Books: An Impossible Mission. Against All Odds. Yet, Somehow, the Chapter Is Saved!" Critical Insights: The American Comic Book. Ed. Joseph Michael Sommers. Ipswich, Mass.: Salem Press, 2015. 73-89. Print.

Smith, Jeff. Bone: The Complete Cartoon Epic in One Volume. Columbus, Ohio: Cartoon Books, 2004. Print.

Spiegelman, Art and Francoise Mouly, Eds. The Toon Treasury of Classic Children's Comics. New York: Abrams Comicarts, 2009. Walker, Brian. The Comics: The Complete Collection. New York: Abrams, 2002. Print.

Weiner, Stephen. Faster Than a Speeding Bullet: The Rise of the Graphic Novel. New York: Nantier, Beall and Minoustchine Publishing, inc., 2003. Print.

Williams, Paul. "Interview: Jeff Smith." The Rise of the American Comics Artist: Creators and Contexts. Ed. Paul Williams and James Lyons. Jackson: U of Mississippi P, 2010, 46-54. Print. http://dx.doi.org/10.14325/mississippi/ 9781604737929.001 .0001 


\title{
6. There Are Some
}

\section{Things You Can't Fix}

\author{
with a Magic Wand
}

\section{POLITICS IN CHILDREN'S COMICS}

Camila Z. Tessler

For most of us, Sunday morning funny pages are a whimsical and pleasant throwback to childhood, with the general perception being that the cartoons presented there are for children. Conversely, political cartoons have long been a staple of newspapers across the world, used to satirize and draw attention to events in the real world and demonstrate the ridiculousness of social and political events as they unfold, and common opinion is that they are for adults. But what happens when these two versions of comics overlap? While it's commonly believed that they are incompatible, the truth is that this meeting of the adult sensibilities of political cartoons and the colorful and cheerful world of children's cartoons is not only common, but historically 
significant in the evolution of children's comics. By examining children's cartoons with content that borders on the political, we can notice that often these cartoons speak to adults, too. Often these cartoons speak to adults by commenting in a way that borrows from both modes and therefore makes it possible for children's cartoons to appeal to both children and adults alike.

In order to discuss fully how children's comics touch on adult themes also found in political cartoons, first there has to be a definition of children's comics as well as a definition of political cartoons. In this paper, children's comics are defined as any comic that is popularly read by children, regardless of the intention and desires of the creator. Generally, comics published in the comics section of the newspaper, particularly the Sunday fullcolor splash pages, were published with the idea to capture a wide audience, children included (See Sanders, elsewhere in this volume). Meanwhile, a political cartoon is "a very specific genre, with its own history, distinctive styles, conventions and communicative purposes. It is an illustration, usually in a single panel, published on the editorial or comments pages of a newspaper” (El Refaie 184). This argument would suggest that political cartoons are designed for adults and that they can be recognized from their inclusion of figures, events, and situations that are thought to be beyond what a child may know and understand (183-184). For the purposes of this paper, then, political cartoons will be those cartoons that are published in the editorial pages, presumably with an adult audience in mind.

However, the fact that a cartoon has elements that are political doesn't necessarily make it a political cartoon. In that same vein, a children's comic does not become a political cartoon as a result of elements that are mildly political. Often, children's comics have a sort of satirical topicality marked by timeliness and a stripped-down shorthand (visual or verbal) that gestures toward 
ideas with political resonance. Such elements acknowledge a dual audience: a child audience who is engaged with play and an adult audience who understands the elements of the comic that are more concerned with the work of political thought.

Historically children's cartoons and political cartoons were often drawn and created by the same people. Tenniel, the famous artist of Alice in Wonderland (1865), was originally a political cartoonist for Punch, a British humor magazine. This fact is important to note because he was requested for the position of illustrating Alice in Wonderland by Lewis Carroll, who had read Tenniel's work in Punch from the time that Carroll was a teenager and enjoyed Tenniel's political commentary (Morris 139). His style of political commentary was then apparent when illustrating Alice. He may have "mined his Punch works for the Alice books" (206), making Alice more political than the books would have been otherwise. His most prominent work until this point was as a political cartoonist, and even when illustrating for children, he would comment on things like class differences, the pope, the judicial system, and gender differences, to name a few (206). This set a precedent for future creators of cartoons for children, but it also provokes the question of why he included these elements at all. For Tenniel, perhaps because he was a cartoonist for the most popular humor and satire magazine of the day, he simply felt more accustomed to including these elements in his cartoons. However, the anticipation that children would not understand the political jokes in Tenniel's illustrations was already present, because Carroll outright explains them in The Nursery Alice (214).

Tenniel as both an illustrator of political and children's cartoons was not an isolated case. Winsor McCay, who wrote Little Nemo in Slumberland (1905, 1914, 1924, 1926), also had a career as a political cartoonist, getting pulled from working on other material to illustrate political cartoons for William Randolph 
Hearst (Heer). Little Nemo in Slumberland tells the story of a boy named Nemo who goes to sleep every night and finds himself in a magical world of dreams, where he's been asked to be the King of Dreams' daughter's playmate. Every night he has an adventure, and at the end of every strip he wakes up, usually with some commentary from either his parents or himself about that night's dream. McCay's Little Nemo in Slumberland ran brokenly from 1905 to 1926, though McCay worked on other projects between 1914 and 1924. Throughout this time the story ranges from silly to serious. While most of the strip focuses on day-to-day (or night-to-night) adventures, occasionally there is commentary that is more aptly aimed at adults than at children. Most of these are moments that happen around Nemo as opposed to actions by Nemo; in the Mars sequence, which ran from April to August of 1910, it's mentioned that people are required to pay for air or they won't be able to speak or breathe at all (McCay 246). The notion of air as a commodity is a remarkably insightful comment, not to mention that it contains a great deal of foresight: present economics echo the notion of public goods being turned into commodities-witness Nestlé's argument that water is not a right but rather a good that should be bought. Another comic, from March 10th of 1907, features a beautiful ice palace being taken apart for the sake of selling the ice (82). This act of destruction could be read as commentary on the act of consumerism and on how the need for money requires the destruction of ephemeral, beautiful things. While it may only be minor commentary, this act is how the storyline ends. Once the palace is taken apart, Nemo and the princess must move on. The commodification of beauty into money simply becomes what forces the storyline along.

Although it is rare that Nemo himself engages in social or political actions (as opposed to the occurrences happening around him), when these actions do make an appearance in the comic they 
are often used to make a particular point. In a sequence spanning from March 22nd to April 19th, 1908 (four full-page strips), Nemo is given a magical wand to fix a dirty and run-down slum called Shanty Town and transform it into an upper-middle-class paradise (McCay 137-140). Gene Kannenberg, Jr. has complained that this sequence is unrealistic and lacking substance because it "exists merely as a narrative excuse for Nemo to demonstrate his fantastic and temporary transformative powers. The narrative offers no concrete economic or sociological reasons why Shanty Town exists in its dilapidated state; while certainly it is presented as undesirable, that fact alone can hardly constitute social criticism" (Kannenberg 9). As we try to explore the places where the critical modes of the editorial and funny pages overlap, certainly we can see that Kannenberg is right that this sequence disappoints as political theory. However, the strip does blend the whimsy and magic of children's comics with a stark sense of the potency of poverty: it says that the issue of poverty is not something likely to be solved through mundane measures. Magic is needed to create a world without poverty, sickness, or ignorance. I do recognize that these powers and this transformation are temporary; after all, they only address the outward signs of poverty, and thus Kannenberg's disappointment is valid. However, my point is that the strip takes a sensibility about an overtly political issue and offers an answer to the problem at home in children's fantasy. In that regard, McCay is presenting a conversation that is a watereddown version of something that might appear in a political cartoon aimed at adults: Is the notion of social reform only something that can be done through magic? It is hard to imagine that this question is aimed at the children reading the cartoon (although they might recognize it), but instead at the adults.

One of McCay's most successful successors in the funny pages is Bill Watterson, who drew and wrote Calvin and Hobbes 
(1985-1995). Watterson was very clear about his career as a political cartoonist. In high school and while drawing political cartoons for his college paper, he realized he had "never paid attention to government, history, politics, or, for that matter, the news" (Watterson The Complete Calvin and Hobbes, vol. 1 7), and he never suspected he was any good. This suspicion proved to be correct, because despite writing editorial and political cartoons, he didn't really find any success until publishing Calvin and Hobbes (8-9).

The dual sensibility latent in Nemo is more central, even cultivated, in Calvin and Hobbes. Watterson covers topics such as political polling, lobbying, and sex discrimination with a certain element of absurdity and play that is well suited to his child protagonist. For instance, in a strip from December 1985, Calvin attempts to get his father to give him more privileges. He takes up the position of a pollster and tells his father that to retain favorable numbers his father should take note that "of all those polled, virtually all favor increased allowances and the commencement of driving lessons" (Watterson The Complete Calvin and Hobbes, vol. 128 ). This is an example of a strip aimed explicitly at a dual audience of both children and adults. While children may be able to understand the concept of polling, it's a joke that's more geared toward adults. But wanting more privileges and more allowance and "playing" at an adult act to get it would be understandable to children. What the strip offers is not political in any pointed way, and, as Kannenberg noted about Nemo, it hardly qualifies as social critique. However, it does point to an awareness of an unequal distribution of power, and the play-acting that it presents addresses that inequality with a note of whimsy. The result is not something only for adults or only for children, but topical satire that, like all satire, is more interested in poking fun than solving problems. It is a satire that acknowledges the power imbalance 
that favors adults and the limited arsenal of responses available to children, both of which are certainly legible to both child and adult readers.

Another strip that is good at finding this balance is Mafalda, a comic strip that was written by Joaquín Salvador Lavado, or Quino, from Argentina. The strip is relatively unknown in the United States, despite being a best-seller around the world (Accorsi 31). It is a comic that focuses on the character of Mafalda, a little girl with a precocious sense of the world around her and a tendency to speak her mind. The strip is, Andres Accorsi claims, "the first reading material that Argentinean comic fans give to their offspring" (31) and operates like Peanuts, which Quino has admitted to using as an influence (Kuntz 72). Quino was a political cartoonist first, working on political humor magazines such as Rico Tipo. While he was to a degree successful his major hit came with Mafalda, and when he finished the comic's decade-long run, he opted to create wordless, single-panel comics (Accorsi 30). Like Watterson, Quino found his true success working with children's cartoons. And even more to the point, Mafalda has found fans in both children and adults in Latin America and the world over, including Taiwan, mainland China, and even Cuba, despite the anti-communist sentiments often expressed in the comic (Kuntz 71-72). Mafalda's facility with such sentiments in a strip for children suggests that the enduring legacy of this comic comes from its ability to speak to both an adult and a child audience.

Although the idea that children's comics could contain something explicitly political might seem strange in North America, Mafalda exemplifies a great deal of comics created in Latin America for children. For instance, in Brazil, the children's comic Perere (1959-1964), by Ziraldo Alves Pinto, was deeply focused on Brazilian national issues. It was cancelled when the military coup d'etat took over the nation, and Maurico de Sousa, 
a figure who is considered the Brazilian Walt Disney, was both censored and blacklisted during this same period (Vergueiro 93). Quino's own life became very difficult after the Argentine military coup, and he eventually fled the country from 1976 to 1983 (Kuntz 71). The censorship of these comics implies that there is a subversive element that other adults recognize as political in a way that would be at home on an editorial page, so at least some of the cartoons' elements are very likely not aimed solely at children. Again, the tradition of political cartoonists who also operate as cartoonists for children leaves a legacy of popular work enjoyed by adults and children alike with these popular artists and writers; this becomes a global trend.

When we look at the similarities in these works by McCay, Watterson, and Quino, which are separated both by time and geography, the same ideas and techniques crop up repeatedly. To begin with, all these children, even Nemo, act in a way that is considered stereotypically childlike for both their time and culture. For instance, Mafalda has a deep and unrelenting hatred of soup that comes up again and again as a repeated gag. Calvin, similarly, is deeply suspicious of new foods. Nemo falls out of the bed due to his enthusiastic dream life more often than he doesn't, often ending the strip with getting yelled at for not staying in bed. These are just examples of how they act in the ways that society expects children to behave.

Another example is through the act of play. Play is one of the fundamental markers of childhood. People perceive play as what children do, and when children's literature aims to make child characters conform to the reader's expectations of children and childhood, often play is used to mark innocence (Larkin-Lieffers 76). By making play a huge part of children's cartoons, these creators highlight child characters as children instead of as small adults. The entirety of Little Nemo in Slumberland can be seen as 
an act of play. Nemo and the princess play dress-up in elaborate costumes, which change with no discernible rhyme or reason. Flip, Nemo's nemesis and friend, and Imp, a jungle "savage" they pick up in an adventure, play multiple iterations of multiple games as they fly, swim, or run from misadventures. While the journeys that these three characters make may appear to be dangerous, the audience knows that because Nemo is dreaming, the worst thing that can happen to Nemo is that he can wake up. Dreaming is the ultimate version of playing pretend. And of course, the idea that the events of the comic are a dream means that this entire universe is created for the purpose of Nemo playing at night when he is meant to be asleep. Calvin's play is a prominent part of the strip, featured in how he relates to Hobbes, his friends, and his parents, as well as how he relates to everyday occurrences like baths, dinnertime, and even homework. In fact, he comments on how this behavior is unique to children to his father, asking, "how come grown-ups don't go out to play?" (Watterson The Complete Calvin and Hobbes, Vol. 3 377). Of the three of these, Mafalda is the one who plays the least, but even she manages to work it into her busy schedule.

Remarkably, often the adult audience is addressed almost directly through the act of play. In one memorable series of strips, Mafalda "plays as liberty." She places a chair on top of an ottoman and climbs up while Felipe, her best friend, questions her on how someone "plays as liberty." In reply, Mafalda takes the pose of Lady Liberty and announces, "with a burnt-out lightbulb in the right hand and a book of fairytales in the left," herself as "Liberty, illuminating the world with her effulgent light!...of 15 watts" (Quino Y Digo Yo...). To an extent, this example is political: the Statue of Liberty is recognized around the world as a symbol of America's relationship to outsiders, and the idea that her torch burns so dimly carries an obvious critique. But, as with the 
example of Nemo's wand, it is a comment that is more satirical than it is political in any focused way. Mafalda's satirical play, therefore, makes a statement in that blurry overlap between the domain of the editorial and funny pages, and she does so in a way that speaks to both audiences. A child might not understand that 15 watts is not very bright or that fairy tales are something stereotypically thought of as soothing to children, but an adult would. And although the exact political (and electrical) references might not speak to a very young reader, the activities of dressup and role-play would be quickly relevant to most. In Calvin and Hobbes, Watterson also interjects comments aimed at an adult audience through the act of play, which should be clumsy but is actually well done even from the beginning. For instance, when Susie responds to Calvin's edict that girls can't enter his clubhouse by announcing that she wasn't interested anyway, Calvin moans, "leave it to a girl to take all the fun out of sex discrimination" (Watterson The Complete Calvin and Hobbes, vol. 129). The child protagonists in these comics use play like children but words like adults to appeal to a dual audience, and although the strips can't fully develop a political argument, their topical satire is neither fully at home in a tradition of adult comics or children's comics.

The reason that commentary being included in play is important is because this combination blends topics in a way that makes the comics enjoyable for a dual audience. However, simply because the children in these comics comment in ways that make them appear more "adult" doesn't mean that they don't understand what they're saying. In the case of Mafalda, for instance, her interaction with her radio and her anxiety over the state of the world, which compels her to put the world (represented by her globe) in bed as "sick" (Quino Y Digo Yo...), indicates that she understands the correlation between what is happening in the world (things like communism, war, and even 
the Cold War, as a child of the sixties) and how this impacts the people who live in the world. The only thing that she can do is put the stand-in for the world in bed. She has no power to take on real, meaningful action because she is a child. And of course, whether the fictional child has any agency to effect change, the real child-and the real adult-can find significant meaning in the strip. Perhaps the specific meaning of the globe and its illness is transparent only to adults, but the sensation of seeing a problem and finding only limited ways to answer it is certainly one that both adults and children can recognize.

There may certainly be more than one reason for this overlap between editorial and funny pages. One may consider that political cartoonists are just unable to resist writing with an adult audience in mind, as was the case with Tenniel. Certainly McCay had a career as a political cartoonist that bracketed his work on Little Nemo in Slumberland, as did Quino with Mafalda. Watterson was, by his own admission, a failed political cartoonist, but for a time at least, he did work in that form. Another reason for adding adult humor of a political nature to children's comics might be to potentially duck some of the worst of censors: Watterson himself claims that the editorial process winnowed a lot of the bad humor, but never does he suggest that social commentary was on the cutting block (Watterson The Complete Calvin and Hobbes vol .112 ). Quino has stated that despite writing in Argentina, where political regimes might make political views dangerous, he has never been censored inside the country (Kuntz 72). Having to self-censor anything dealing with sexuality or the church doesn't seem to have stopped Quino from the political commentary he managed to include within Mafalda. By inserting political issues into children's comic strips, not only do these cartoonists have the ability to promote their own political views, but they also have the ability to influence an audience (both children and adults) 
who might not read the political cartoons in the editorial section. Further, they can speak to adults as well as children in a place where the censors may not be reading closely for commentary. Children's comics that feature political elements lighten the mood more than does the political cartoon and make the politics understandable to a broader audience.

By including commentary with political elements in children's cartoons, what the respective cartoonists have done is create a two-level reading that appeals in a satisfying way to adults and children alike. The creation of child characters who engage in childhood activities such as play and who are subject to the whims of adults but who have the savvy of adults when it comes to social and political commentary helps the artists develop this appeal. Perhaps this blend is why these comics did so well, both in marketability and in longevity. For instance, Quino and Watterson chose to end their runs as opposed to being cancelled, and McCay went back to Slumberland again and again. Whether inserting political elements was to be used as a teaching device, to further the personal beliefs of the artist, or to evade censors who might not look closely at children's media, what has resulted is an art form that speaks both to children and adults and has given these comics lasting power through much of the 20th century.

\section{Works Cited}

Accorsi, Andres. "Argentine Comics: A History." Cartooning in Latin America. Ed. Lent, John A. Cresskill, New Jersey: Hampton Press, Inc, 2005. 25-46. Print.

Eco, Umberto. "Mafalda La Disconforme." Confirmado (1966). Print. 
El Refaie, Elisabeth. "Multiliteracies: How Readers Interpret Political Cartoons." Visual Communication 8.2 (2009): 181-205. Print. http://dx.doi.org/10.1177/1470357209102113

Grossman, Ron. "The Magic of Sunday Comics." The Chicago Tribune 2014. Web. January 420162016.

Heer, Jeet. "Little Nemo in Comicsland." 2006. Web. December 6 2015.

Kannenberg, Gene Jr. "'Little Nemo in Shanty Town" and beyond: Social Commentary in the Works of Winsor McCay." Folder 2. Winsor McCay Biographical Files. Billy Ireland Cartoon Library and Museum, The Ohio State University, Columbus, Ohio. January 4, 2016.

Kuntz, Lucia Iglesias. "Quino, on the Funny Side of Freedom." UNESCO: The Courier 2000. Print.

Larkin-Lieffers, Patricia A. "Images Of Childhood And The Implied Reader In Young Children's Information Books." Literacy 44.2 (2010): 76-82. Education Research Complete. Web. 9 Jan. 2016.

McCay, Winsor. Little Nemo in Slumberland: Little Nemo in the Land of Wonderful Dreams, 1905-1914. Köln: Evergreen, 2000. Print.

Morris, Frankie. Artist of Wonderland: The Life, Political Cartoons, and Illustrations of Tenniel. Charlottesville, Virginia: University of Virginia Press, 2005. Print.

Quino. Mafalda \& Friends. Trans. Cullen, Terry. Vol. 1. Buenos Aires, Argentina: Ediciones La Flor, 2005. Print.

-. Y Digo Yo... Spain: Noveno Arte, 1974. Print.

Vergueiro, Waldomiro C.S. "Children's Comics in Brazil: From Chiquinho to Monica." Cartooning in Latin America. Ed. John A. Lent. Cresskill, New Jersey: Hampton Press, 2005. 85-100. Print. Watterson, Bill. The Complete Calvin and Hobbes. Vol. 1. Atlanta, Georgia: Lionheart Books, Ltd., 2005. Print. 
120 Good Grief! Children and Comics

-. The Complete Calvin and Hobbes. Vol. 3. Atlanta, Georgia: Lionheart Books, Ltd., 2005. Print. 


\title{
7. The Character in
}

\author{
the Mask
}

\section{AN ANALYSIS OF MASK IN ART SPIEGELMAN'S \\ MAUS}

\section{Taraneh Matloob Haghanikar}

Maus, by Art Spiegelman, consists of two parallel narratives. One is a story narrated by the author's father, Vladek Spiegelman, who, through a series of interviews, shares the horrors of the Holocaust with his son. The second narrative belongs to the author, who recalls and expresses his strained relationship with his father. Through these two narratives, it becomes clear that for the Spiegelman family, the Holocaust does not end in 1945. Both the father and the son are significantly scarred by their experiences. Vladek, a Jew in Nazi-occupied Poland and later in the Auschwitz Concentration Camp, endures the ever-present threat of death, humiliation, and horror. Also, Art, a child born after the Holocaust and "the heir of a non possessed experience" (LaCapra 154), suffers 
from the post-traumatic isolation and depression of the war present in their family. Maus is their survival tale.

The grave and horrific events of Maus, along with the scarcity of child characters, make discussing the book in the context of children's comics a strange, but not impossible, task. As Maria Nikolajeva indicates, "empirical research shows that children prefer to read about characters of their own age or some years older" (7), and since the majority of the characters in Spiegelman's tale are well into their adult years, such research hints that Maus should not be considered for readers under the age of eighteen. Furthermore, even the one element of Maus that makes it appear to be for children-the anthropomorphized animal characters-is really more a marker of its history as a comic for adults than for children. Spiegelman and other underground comix artists used the funny animal genre in venues that were expressly not for children. In particular, an early version of Maus first appeared in 1972, when Spiegelman's three-page comic was published in the Funny Animals underground comix anthology. The anthology's countercultural message made clear that the use of talking animals in this early version of Maus was not evidence that the book was for children. ${ }^{1}$

However, if Maus was not intended for young children, it should come as no surprise that it is nonetheless very popular with young adult readers as well as adult readers. Perhaps that popularity comes about because, as Phil Nel writes, "readers of different ages, different degrees of aesthetic experience, different kinds of emotional experience" may receive different levels of meaning from the same book. As he further discusses, "books are for all who are ready to listen to them [;] ... for all who recognize that art cannot be confined within ... narrow labels" 
(Nel). Also, it is noteworthy to remember that "Maus has been taught widely in U.S. high schools, and even elementary schools, as part of the literature curriculum for many years" (Canadian Polish Congress 1). Intended for teens or not, then, the book is frequently assigned to them, presumably within a classroom context that helps them make personal sense of it. Together with being a primary or a supplementary resource for middle and high school students, Maus might appeal to young readers who, like the narrator in the book, are in the process of discovering and shaping their own identity. In the same way that the narratorprotagonist Artie struggles with distinguishing between his own and his family identities, readers may experience the societal pressure of identifying themselves as they navigate between their personal and public worlds.

In this regard, one of Maus's persistent themes-masking-raises fundamental questions about the constructions of identity and double identities and provides the basis for understanding the tension between conflicting aspects of characters' identity. In particular, masking provides an increasing recognition that identities are not fixed. Instead of dividing the personal identity from the public, Maus constantly demonstrates the inconsistencies of these two forms of identity and calls attention to the ways these forms collapse into each other. Given this view, the aims of this paper are two-fold: firstly, to represent five different forms of doubleness created by the masking, and, secondly, to suggest how each form reinforces how personalpublic identities are subject to change. In this respect, the following discussion explores different levels of personal identity and double identity in Art Spiegelman's two-volume graphic novel Maus: A Survivor's Tale, examining visual and verbal narratives. "Personal identity" is identity in the familiar form: the state of having or showing characteristics by which people are recognized 
by others or by which they recognize themselves (Biro). Implicit in this definition is that personal identity is "developmental, and is entirely dependent on the influence of variables such as race, culture, religion, family, ideology, and embodiment" (Coats). Closely related to the notion of personal identity is the concept of doubleness or double identity. Borrowing from the sociologist Charles H. Cooley in 1902, Karen Coats introduces "the looking glass self," whereby the sense of identity emerges through how one imagines others to perceive him or her. "This 'looking glass self' is not," as Beverly Daniel Tatum writes, "a flat one-dimensional reflection, but multidimensional" (18). In many ways and under extreme circumstances, this self-awareness may force people to have public and private faces at the same time, developing a double perspective and a double consciousness. While people want to embrace their personal characteristics, they are drawn to conform to the agents and groups with the most power. As a result, people's private identity repeatedly conflicts with their public identities. With many different forms of doubleness in every society and culture, double identity in this paper is defined as identification with one's lack of a "cohesive, unified sense of self" (Tatum 20), embracing one aspect and disguising the other whenever necessary. It is the tension between these two kinds of identity that makes Maus not just a legitimate text for teens, but perhaps even an ideal text.

Also, Spiegelman's use of his anthropomorphic trope has more to do with the conflict of personal and public identities than in most cartoon representations of animals. Suzanne Keen explains that " $\mathrm{t}]$ he technique of representing groups and types by reference to an allegorized animal kingdom of course predates comic books and graphic novels, calling upon a long literary tradition of moralized animal fables, political allegories, and myths of origin in folklore" (137), but even these uses are too general 
for Spiegelman's purpose. Rather, Maus casts its characters as animals to portray the "dehumanization" ("Why Maus" 4) that was at the very heart of the Holocaust. Indeed, Spiegelman attributes a range of animal appearances, traits, and emotions to humans not to practice anthropomorphism but to employ a category that resonates the characters' identity conflicts. Spiegelman captures Hitler's categorization of Jews as inhuman when he quotes Hitler as saying, "The Jews are undoubtedly a race, but they are not human" (Maus I 4). The verbal as well as visual narratives in Maus gesture toward the dehumanized victims of the Nazi camps. Given this view, Spiegelman's depiction of people with animal masks aims not to conceal their human identity but to expose their double identity, the conflict between their understanding of themselves and the public identity of Jews that Hitler insisted they adopt. In view of that conflict, it seems within these two volumes the characters' inhuman identity is superordinate to their human identity: their public, dehumanized identity trumps their sense of themselves as valid human beings.

The conflict between the imposed, public, dehumanizing identities of Spiegelman's characters and the internal, personal, inevitably humanizing identities of the characters is particularly dramatized in the way that Spiegelman portrays their animal identities as natural or unnatural, especially when those identities are worn as literal masks. Masks are often associated with more than one meaning and are therefore especially well suited to indicate the double nature of their wearers. Masks have literal meanings for particular occasions or specific jobs. Jobs, of course, are fundamentally tied to public perception of one's identity. Spiegelman uses a visible exterior such as the animal mask to play up the conflict between the public identity and private identity of the characters. At times, in fact, Maus's masks reveal the true identity of the wearer. Therefore, masking in Maus not only covers 
the face, but, more importantly, changes behavior and appearance in public. It presents molding of individual goals and interests to accord with the welfare of the larger community and portrays a sense of people's identity within the group. Individuals, specifically Vladek and Artie, the two main narrators of the story, obtain self-awareness only by being masked: they internalize the attitudes others take towards them as social relations and present their behavior to others through the animal mask they wear. In this regard, Maus explores the tension between their public and personal identities as represented by their animality (and humanity) in five different ways.

\section{First Form of Double Identity}

Within the first form of double identity in Maus, people appear to be animal-humans, not human beings wearing animal masks (see fig. 1 and 2). As depicted in these two images, the characters look like animals, and their most distinctive animal part is their heads and thus their faces-which is supposed to be the most human; meanwhile they have human hands, human feet, the posture of human bodies, and they also show different human traits. Looking at these characters, it seems they are neither uniquely human nor exclusively animal, and "it remains unclear whether there are human faces beneath or whether there are masks all the way down" (LaCapra 163). While the characters' faces look like mice, their other traits do not reflect animal behavior. For example, as depicted in Figure 1, Vladek's body posture and compassion are expressions of understanding and care for Anja. Meanwhile, Anja's suffering and hardship is best represented through her "screaming mouth" (Meta 145) and her objection to Vladek's sympathy by saying, "why are you pulling me, Vladek. Let me 
alone. I don't want to live!" (Maus I 122). As Spiegelman explains further,

When I show the mouths, they're almost always there as cries and screams [...] It's that triangle inverted as you look at it from underneath with a kind of scream face. It allows for a kind of vulnerability, coming in toward the underbelly of the mouse. The screaming mouth completes the face; it's a way of making that face human. (Meta 145)

Also in this regard, it is noteworthy that "these characters might look like mice, or cats, or pigs, but what they are is people. They have the complexity and the surprisingness of human beings" (Pullman). Furthermore, Figure 2 depicts mice-people as "pathetic and defenseless creatures" (Meta 125). However, their striped prisoner uniforms make them instantly identifiable as imprisoned humans. Unlike other types of human clothing, a prison uniform is worn reluctantly and is a sign of punishment and oppression. Given this view, the first form of double identity in Maus emphasizes that these imprisoned characters are humans, but they are likened to animals. Their humanity, perceived internally through their personal identity, is in conflict with their public identity.

The new field of animal studies offers further insight about the relationship between human beings and other animals. In Maus, animals are given a prominent position, but that position is very complex and ambiguous. So it is easy to believe that animals and humans are inherently different from each other, to ignore what James Stanescu calls our "shared vulnerability" (Stanescu 574), and to avoid becoming "engage[d] in disavowal" (568) when animals are treated unfairly. Stanescu's argument, as well as the 
argument of animal studies theorists in general, thus seeks to emphasize our need as a society to think more critically about humans, animals, their relationship, and the relevant ethical considerations. For such theorists, it is the ability of humans and non-human animals "to be wounded," and thus it is "our very dependency that brings us together" (578). Human resemblance to animals in Maus, therefore, can be perceived as a metaphor of being wounded, oppressed, and troubled. Since mice are a metaphor for Jews, it is possible to speak of Jews and represent them symbolically, as they are human beings. In other words, Spiegelman both goes along with the typical understanding of a split between humans and animals in showing how the public persona of human beings is used to oppress them and manages to find humanity in the animal characters, which means he also thwarts the common understanding of the split between human and animal.

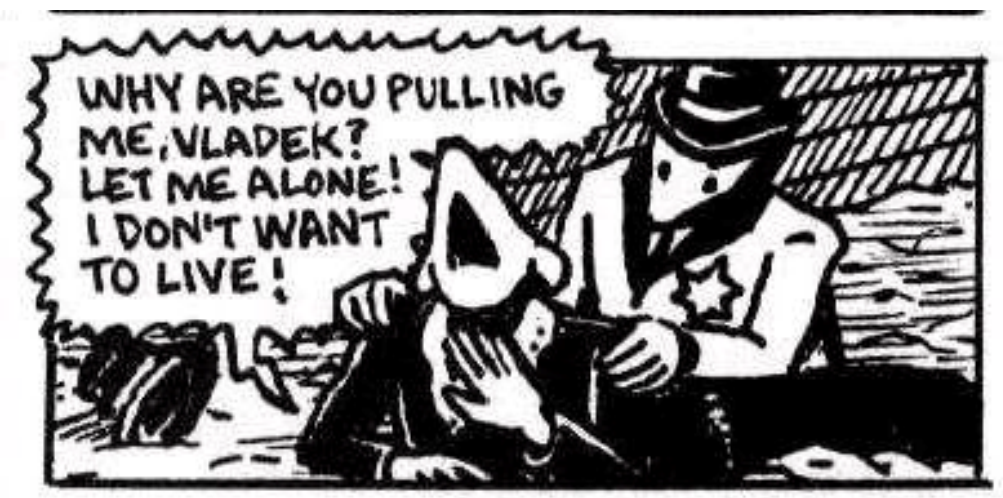

Figure 1. “Maus I 122”. Copyright (c) 1973. 


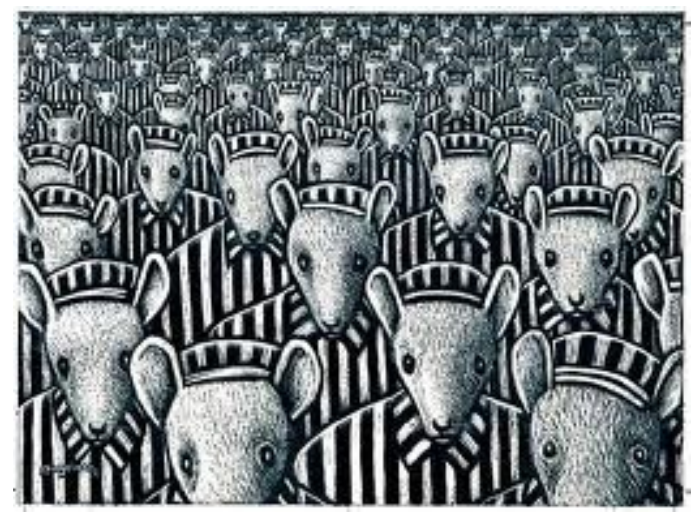

Figure 2. “Maus II”. Copyright $\odot 1986$.

\section{Second Form of Double Identity}

The second form of double identity in Maus portrays characters as real human beings, as opposed to animal-humans. One illustrative example is Vladek's letter and picture sent from the Auschwitz Concentration Camp to his family. As Figure 3 shows, Anja receives the letter from her husband and exclaims, "And here's a picture of him: My God-Vladek is really alive!” (Maus II 134). The real photograph of Vladek shows him as a human, not as a mouse. In contrast, the other panels on the same page feature Vladek as an aged animal-human being interviewed by his son, and, interestingly, they are both depicted as mice. Unlike other illustrated images, Vladek's photograph, posing in his prisoner uniform, is not drawn, but has been captured by a real camera at some other point in his lifetime. The juxtaposition of him as a human and a mouse provides a testimony, a form of evidence in support of all that has been narrated visually and verbally throughout the book. Art's choice to include a real photograph may seem counter-intuitive as an attentive viewer expects to see 
all characters in their illustrated form. However, this choice draws significant attention to Vladek's personal identity, "not a mouse any longer, but a man: a handsome man, a strong man, a proud and wary man in the prime of life who has survived appalling suffering" (Pullman). This portrait of Spiegelman's father reveals his true individual identity buried under the horror of the Holocaust. Paradoxically, this photograph of Vladek as he looked in the past is heavily skewed in one direction, not integrated into Spiegelman's other panels in the book. Through ongoing examination of conflicts between personal and public identities, we come to realize that Vladek has no desire to or cannot remember his individual persona. He is mainly overwhelmed by the compulsive memories and characteristics of his public identity, the identity of the mouse, the victim to the memoir's German cats.

\section{Third Form of Double Identity}

The third form of double identity in Maus is the figure of animalmasked humans. As depicted in Figures 4 and 5, Spiegelman draws himself as a human and an artist wearing a mouse mask. This particular combination of humans and their animal masks represents a significant transformation in the outward appearance of one of the main characters. It seems that through the course of the creation of Maus, something has changed. The altered narrator "has become a different person or persona due to the publication of the first volume of Maus" (Klepper 98). Spiegelman "draws Art seated at his drawing board on top of a pile of mouse corpses" (Rothberg). This is the first time he depicts himself "with a human head now wearing his former persona as a mask" (Klepper 98). The animal mask on his face is removable and temporary, and under that loose mask, he has a human head. However, as demonstrated in Figure 5, this Spiegelman as "a mouse-masked human contrasts 

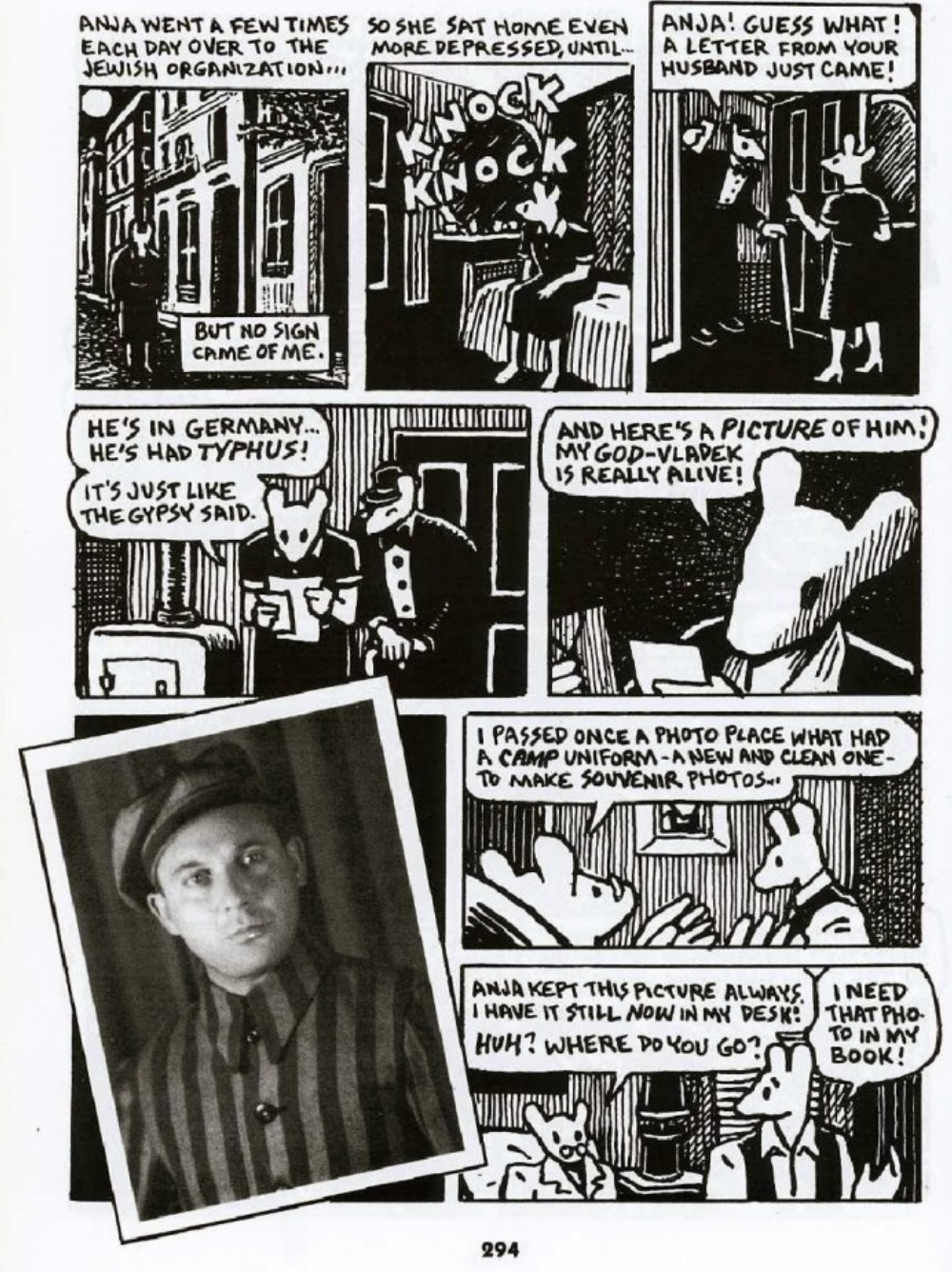

Figure 3. "Maus II 134”. Copyright $\odot 1986$ 
strikingly with the mouse-headed bodies piled below him" (Baetens 86). In particular, the mask is "the only thing protecting him from the rotting corpses (and the flies buzzing around and above them)" (Johnston). This contrast reminds us that as an artist, Spiegelman is accomplished because of the successful completion of the first volume, yet it is devastating to build a success based on telling the story of "the dead six million" Jews (Baetens 86).

Vladek survives the Holocaust, but the constant recalling of the traumatizing events leaves him emotionally crippled. Anja, Art's mother, survives the Holocaust as well, but she commits suicide in 1968. Art Spiegelman, "the secondary victim of events" (Klepper 97) and the son of these Holocaust survivors, struggles to comprehend the unresolved trauma his family has experienced. On the one hand, he feels a pressure to maintain a wounded identity with his parents, and on the other hand he attempts to develop a new distinct identification. The tireless process of interviewing his father, along with the struggle of their ongoing daily relationship, keeps Spiegelman's artistic voice prominent as the facilitator behind the scenes of the memoir. The "process of translation/interpretation makes it possible for him [the author] and the reader to confront history ('his father's passage through hell')" (Klepper 96). However, as Ian Johnston indicates, what makes Art Spiegelman different from his father is the fact that Artie addresses his pain: he speaks out. If his artistic creation is inconclusive, contradictory, and elusive, he does the only thing any of us can do-he makes the attempt. Exploring Vladek's past and his repressed memories of the war, Spiegelman calls into question his own emotional tolerance for continuing the journey he has already started. By completing the first volume, he is not a passive spectator of the harsh brutality anymore. He has initiated a project, a huge exhibition, and therefore all readers, critics, and those who acclaim or condemn Maus I are witnesses. Meanwhile, 
completing the task appears not thrilling but extremely painful. Not only is he building a career out of the story of dead Jews, but he is also putting on the victim-Jew persona of the mouse in order to fit the public role (of victim-Jew) that the broader society recognizes when it sees the publicity image (see Figure 4). Exploring this severe tension between his private and public identities, Art Spiegelman takes great pains "to deal with the events on his mind: his father's death, ... the publication of Maus I, [and] his resulting success and fame" (Klepper 98). In spite of developing a successful public image, he is targeted by the overwhelming publicity he receives. As Figures $\mathbf{4}$ and $\mathbf{5}$ indicate, the reporters invade his private space as they prepare him for his publicity photo: "Alright Mr. Spiegelman ... We're ready to shoot!" (Maus II 41). In other words, publicity consciousness has been imposed on him by outside circumstances.

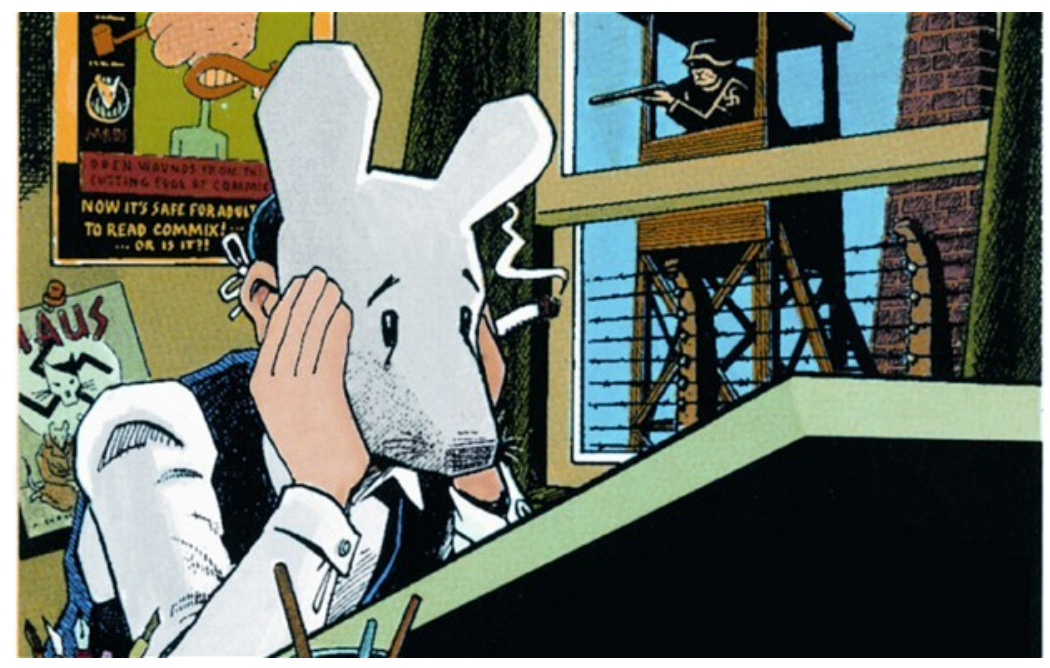

Figure 4. "Maus II Book Jacket". Copyright $\odot 1986$. 
Time flies...
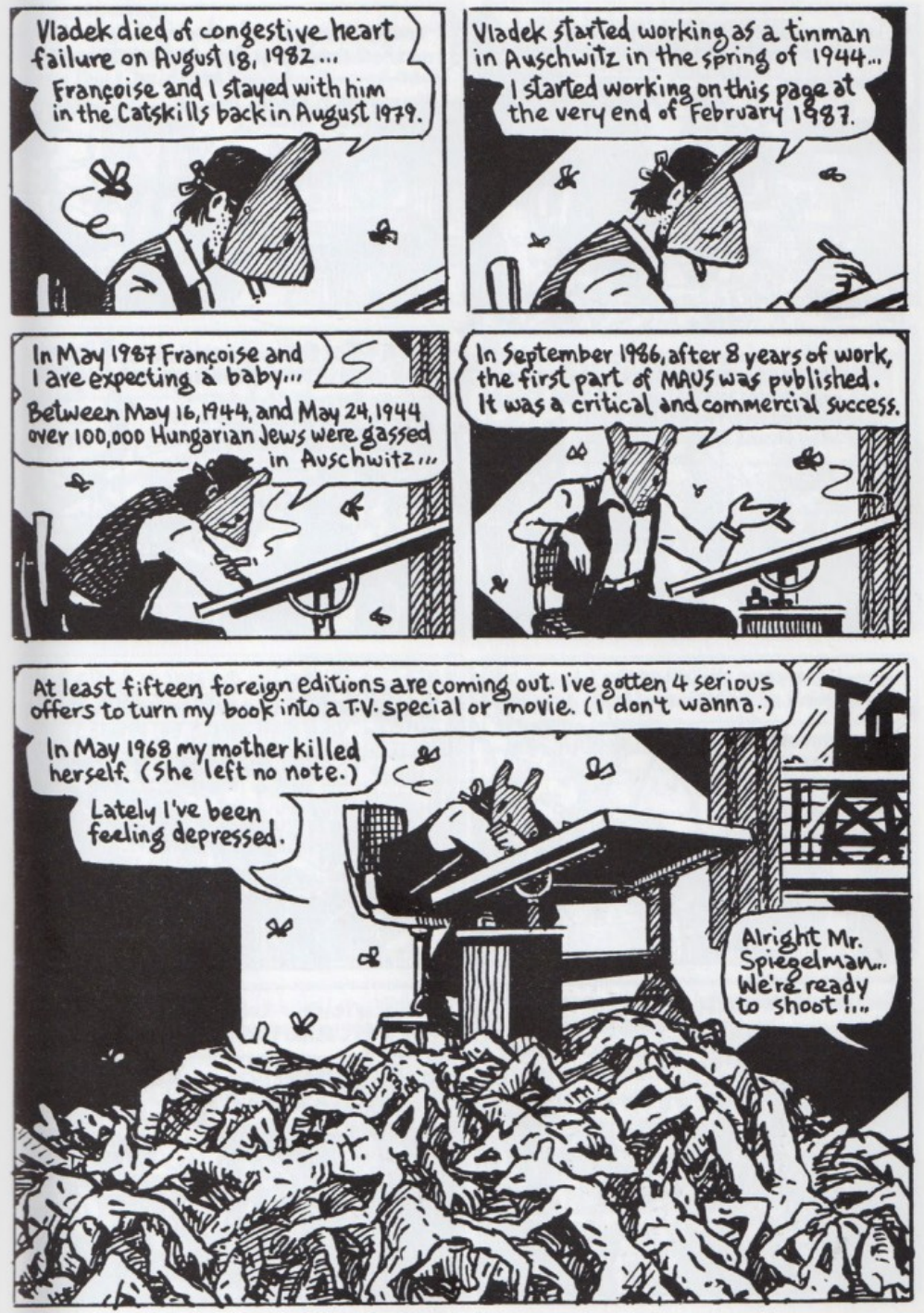

Figure 5. “Maus II 41”. Copyright (c) 1986. 


\section{Fourth Form of Double Identity}

The fourth form of double identity in Maus refers to humans with animal heads but covered with a different animal mask. Replacing one animal face with another gives the animal-humans a secret identity. Indeed, characters wear the masks of different animals to avoid detection in unsafe circumstances. In order to protect themselves, their friends, and their loved ones, these characters wear masks and keep their anonymity. By pretending to be other animals, they alternate between two entirely different identities, adopting the one that provides them more security. For example, “when Jews within Maus' narrative actively attempt to pass for non-Jewish Poles, they are depicted wearing pig masks, a graphic representation of their struggle to stand part from or outside of their own ethnicity, their Jewishness" (Baetens 83). What is striking here is that Jewish-Pole characters in the book wear a double mask of pigs while Christian-Poles are depicted as pigs without a removable mask. On closer examination, it becomes apparent that characters wear the masks of different animals to reflect their sense of belonging to a group. When the Jewish Poles wear pig masks, they disguise themselves as non-Jew Polish characters. Associating Christian Polish identity with temporary and removable masks, Spiegelman emphasizes the permanence and significance of the Jewish values, interests, and concerns beneath the pig mask. In fact, the created image implies that one's personal identity as a Jew is more important than one's national identity. In contrast, all Christian Poles are represented with the pig identity: for them, though, the personal and public identities are the same. What makes these Christian Polish characters appear as pigs is not their common personal traits but their membership in a bigger religious and ethnic community, one that is non-Jewish. 
Given the above discussion, the fourth form of double identity appears to complicate and dramatically change the notion of double identity throughout the book because the characters have two visibly noticeable identities that seem to be mutually exclusive. Their public persona requires them to wear a second mask, while their private character is buried under the mask. The extreme conflict between defining the individual and public identities raises questions about double masking as the most superficial form of outward appearance. The lack of freedom in choosing their public faces obligates the characters to racial, social, and national conformity. In reading and analyzing this type of double identity, sometimes the distinction concerning which character is the real one and which is the fake is blurred. This is mainly because in some panels "even we, as privileged readers, are at first kept in the dark" (Baetens 83). Only when the characters identify themselves as one race or nationality are readers allowed to discover that the mask is temporary and the characters are in the process of hiding or revealing their identities.

\section{Fifth Form of Double Identity}

The fifth and final form of double identity in Maus demonstrates "real animals that contrast with the figurative ones" (LaCapra 161). For example, "the vermin-like Jews are afraid of 'real' rats in a bunker [...] The Germans have vicious dogs. And Artie's analyst has a photo of a cat on his desk" (LaCapra 161). The most striking aspect of this type of demonstration is that the characters implicitly reveal their human side. Although they look like mice, "no Jew [in the book] states that he or she feels or felt like a mouse" (LaCapra 169). Instead, they are scared of real rats. While it is true that real mice, like humans, get easily terrified of rats, their fear behavior is very different from human beings. Real mice 
detect rats not by seeing but through "detection and processing of fear-evoking odors emitted from" them (Papes, Logan and Stowers 692). Humans generally consider rats to be unpleasant creatures, a nuisance. As depicted in Figure 6, Vladek attempts to soothe Anja when he tells her, “Those aren't rats. They're very small. One ran over my hand before. They're just mice!” (Maus I 147) Later, he confesses to Artie, "Of course, it was really rats. But I wanted Anja to feel more easy" (Maus I 147). The reality of the rat and some other real animals in Maus reinforces that these human-sized mice are afraid of rat-sized rats because the mice in this book have human understandings of what rats are like, and therefore they show a (human) "startle response" (Stolerman 1276), a peculiar and sudden defensive reflection to alarming and unexpected situations, such as seeing rats. The physiological reaction of these Jews-micehumans to the rats as depicted in the book suggests that although the characters look like animals, they react as most human beings normally do.

\section{Final Thoughts}

Much violence, terror, and loss are depicted in Maus I and II. The verbal and visual narratives of these two volumes demonstrate how Art is involved with and at the same time longs to become estranged from his parents' horrific experiences of the Holocaust. His tight connection to the intimate witnesses of the war and his desire for the alienation from the surrounded collective melancholy leave him with a deep sense of a double identity. In order to understand the nature of the doubleness expressed in the book, it is crucial to note that Maus does not simply portray the violence that occurs during the Nazi occupation. Rather, it also parallels Art's personal responses to the violent events experienced by his parents. To deal with the unresolved grief of 


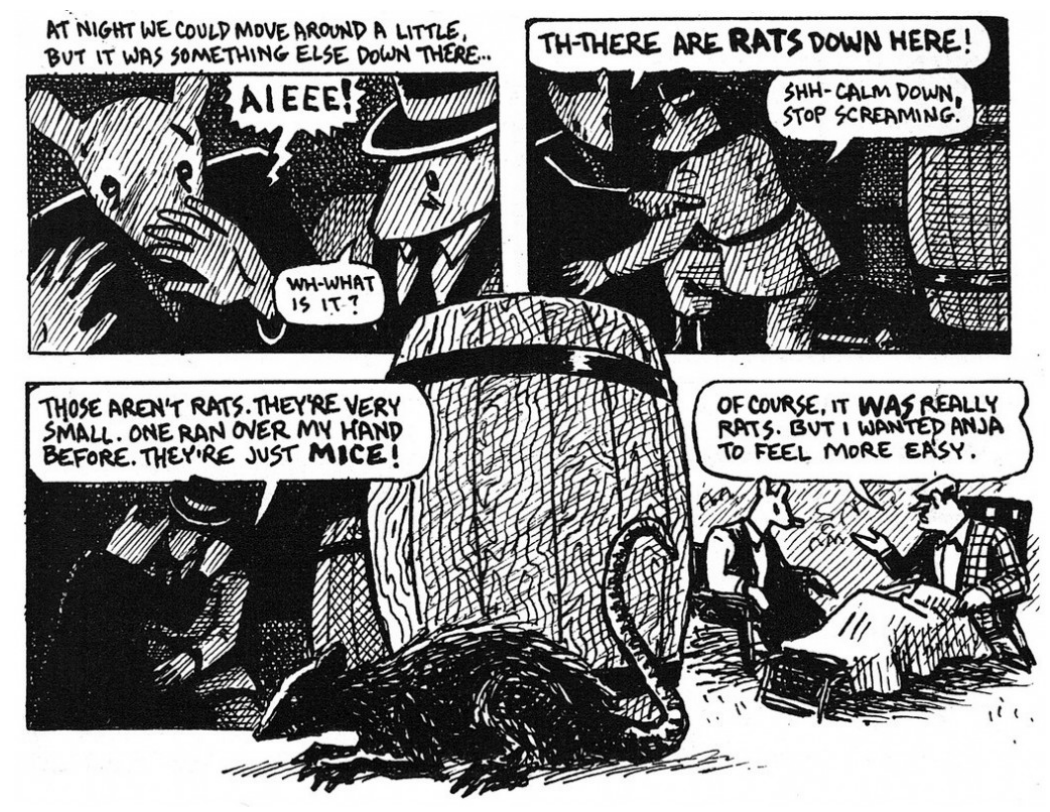

Figure 6. "Maus I 147”. Copyright @ 1973.

the Holocaust in his family, Art reveals what he has experienced with rigorous and remarkable frankness. In a conversation with Francoise, he shares his doubts about his ability to continue the Maus project when he explains, "I feel so inadequate trying to reconstruct a reality that was worse than my darkest dream...There's so much I'll never be able to understand or visualize...so much has to be left out or distorted" (Maus II 16). So it seems that "Art is worrying about art-about his art, and what it's doing to himself and to its subject matter" (Pullman). His goal therefore is not to provide a moralistic lesson but to reflect the complexity and brutality of reality as it is, a reality that is fundamentally about negotiations over Jewish identity, how deep it runs, what trauma it carries, and how it can be recognized. 
In addition to experiencing the horrors of reality inherent in the Holocaust, Art Spiegelman also watches the collapse of the Twin Towers on September 11, this time as a firsthand, not secondary witness. He shares his personal recollections of that tragic day, the aftermath of 9/11, and also his political opinions in a collection of unconventional comic strips called In the Shadow of No Towers. Throughout this book, "the mouse figure appears seven times and applies only to Spiegelman and his immediate family [including his wife and his children,] rather than to the Jews in general" (Versluys 984). Spiegelman's portrayal of himself and his family as mice in No Towers "does not mean that ... [he] arrogates to himself the role of Holocaust victim. What it does signify is that suffering a primary trauma as a close 9/11 witness allows Spiegelman to position himself within a larger Jewish tradition" (Versluys 985). Spiegelman's re-use of the mouse metaphor in No Towers is certainly not a coincidence, but tackles the continuation of his identity conflict in a post 9/11 lifestyle. For example, on one panel, when he looks at himself in a mirror, his face transforms from clean shaven, to unshaven and full bearded, to clean shaven again, and eventually to that of a mouse (In the Shadow 2). Another instance is the image of Spiegelman, in his mouse figure, dozing off at his drawing desk (In the Shadow 2). In contrast to the similar scene in Maus, this panel has no mouse corpses, but it pictures the artist's new dilemma as being "equally terrorized by Al-Qaeda and by his own government" (In the Shadow 2). Using the mouse figure in No Towers to a great extent emphasizes the helpless and paranoid state of Spiegelman's mind. Looking perplexed and terrified throughout the book, it seems Art Spiegelman is attempting to claim his identity through calling attention to his self-created Maus persona. The link between Maus and In the Shadow of No Towers is thus marked by his struggle in constructing 
his identity from being the secondhand victim to becoming the firsthand witness of the trauma.

Reviewing all five forms of double identity with different levels of complexity in these two volumes suggests that the rationale for using masks is threefold: First, "masks can force viewers to examine the character behind them all the more closely" (Baetens 83). By introducing the cast of disguised characters, Spiegelman draws everyone's attention to inquire and investigate more about what has been covered. Second, in addition to being mysterious, by wearing animal masks, these characters do not impersonate the animals; they do not imitate or reflect animal characteristics, such as their behavior, speech, or expressions. On the contrary, they demonstrate "the falseness of the environment" (LaCapra 164) in which they live, drawing attention to the falseness nurtured by the Holocaust and postwar. The contradictory animal-human representation is indeed a striking instance of the hideousness of war describing the state of being untrue and artificial. Third, assigning animal heads to human characters, specifically to Vladek and Artie, the two main narrators of the story, reflects what W.E.B. Du Bois famously called "a conflict and interaction between the internal and external visions of the self," and it implies the "sense of always looking at one's self through the eyes of others, of measuring one's soul by the tape of a world that looks on in amused contempt and pity" (Du Bois 2).

Examining how all of these five forms of masking are interrelated, two major themes of conformity and resistance stand out. Noteworthy is that these trends are not mutually exclusive. Regarding the theme of conformity, the fourth form of double identity represents characters adopting masking so as to make their public identity more visible. The individuals adopting these forms conform to being recognized by the groups with the most 
power and authority. They therefore behave according to the standards of behavior that are expected by their group. The individuals representing this theme only experience their identity through others' acts of recognition. Otherwise, separated from the group, they are lost and unidentifiable. In contrast, the first, second, third, and fifth forms of double identity reveal resistance as another facet of masking. A resisting character is an individual who senses his or her personal self, values, preferences, and choices. Characters representing this trend are capable of wanting to be different; however, their skills and abilities are too weak, undeveloped, or damaged in practice. They are under pressure to conform their personal identities to models imposed by society, so they adopt a range of strategies of resistance for their oppressive environment. However, their resistance is not an active practice but a silent internalized struggle. Resisting characters fail to make forceful efforts to get free of restraint, but they are aware, suffer, and struggle with the constriction.

While Spiegelman's art is primarily regarded as a form of personal and family memoir, it also offers unique opportunities to a wide range of readers. Consciously or unconsciously, Art Spiegelman incorporates trauma into his art and demonstrates it through the alchemy of his unconventional artistry. The doubt, confusion, and challenge of the ongoing process of Spiegelman's self-examination is reflected in his books' power to evoke a wide range of responses from various individuals, including adults and young adults. For those young adult readers who suffer confusion, self-loathing, and depression and are angered by different kinds of oppression, Maus serves as an example to illustrate the complicated process of self-discovery, but it offers no reassurance. Spiegelman's journey for his true self continues even after the completion of the Maus series. Spiegelman's identity crisis therefore is understood as a process, providing him with an 
opportunity to channel his frustrations as well as his efforts into public display.

\section{Works Cited}

Baetens, Jan. The Graphic Novel. Leuven, Belgium: Leuven UP, 2001.

Biro, John I. "Personal Identity." Encyclopedia of Empiricism. Eds. Don Garrett and Edward Barbanell. London: Routledge, 1997. Credo Reference. Web. 25 Dec. 2015.

Canadian Polish Congress. The Problems with Spiegelman's Maus: Why Maus Should Not Be Taught in High Schools or Elementary Schools. June 2015. 20 Nov. 2015 http://www.kpk-toronto.org/ 2014/docs/maus_2014_why_it_should_not_be_taught.pdf

Coats, Karen. "Identity." Keywords for Children's Literature. Eds. Philip Nel and Lissa Paul. New York: New York University Press, 2011. Credo Reference. Web. 26 Dec. 2015.

Du Bois, W.E.B. The Souls of Black Folk. 1903. Mineola, NY: Dover Publications, 1994.

Johnston, Ian. “On Spiegelman's Maus I and II." johnstonia. 28 Dec. 2001. 27 Dec. 2015. http://records.viu.ca/ Johnstoi/introser/ maus.htm

Keen, Suzanne. "Fast Tracks to Narrative Empathy: Anthropomorphism and Dehumanization in Graphic Narratives.” Substance 40.1 (2011): 135-155. http://dx.doi.org/ 10.1353/sub.2011.0003

Klepper, Martin. "Emergent Art: Textual Identity in Art Spiegelman's Maus." Anglistik 18.2 (2007): 83-101.

LaCapra, Dominick. History and Memory after Auschwitz. New York, NY: Cornell UP, 1998. 
Nel, Philip. “A Manifesto for Children's Literature; or, Reading Harold as a Teenager." Nine Kinds of Pie. Philip Nel's Blog. 28 April 2013. Web. 20 December 2015. http://www.philnel.com/2013/04/28/manifesto/

Nikolajeva, Maria. The Rhetoric of Character in Children's Literature. Lanham, MD: Scarecrow Press, 2002.

Papes, Fabio, W. Logan Darren, and Lisa Stowers. "The Vomeronasal Organ Mediates Interspecies Defensive Behaviors through Detection of Protein Pheromone Homologs." Cell 141 (2010): 692-703. http://dx.doi.org/10.1353/sub.2011.0003

Pullman, Philip. "Behind the Masks." Guardian. 17 Oct. 2003. 12 Nov. 2015. http://www.guardian.co.uk/books/2003/oct/18/ fiction.art

Rifas, Leonard. "Funny Animal Comics." Encyclopedia of Comic Books and Graphic Novels. Ed. M. Keith Booker. Santa Barbara, CA: Greenwood, 2010. 234-242.

Rothberg, Michael. "We Were Talking Jewish: Art Spiegelman's Maus as Holocaust Production.” Contemporary Literature 35.4 (1994): 661.

Spiegelman, Art. In the Shadow of No Towers. New York, NY: Pantheon Books, 2004.

-. Maus: A Survivor's Tale, Volume I. New York, NY: Pantheon Books, 1973.

-. Maus: A Survivor's Tale, Volume II. New York, NY: Pantheon Books, 1986.

-. MetaMaus: A Look inside a Modern Classic, Maus. New York, NY: Pantheon Books, 2011.

-. Why Mice? 20 Oct. 2011. 15 Nov. 2015 http://www.nybooks.com/blogs/nyrblog/2011/oct/20/whymice/ 
Stanescu, James. "Species Trouble: Judith Butler, Mourning, and the Precarious Lives of Animals." Hypatia 27.3 (2012): 567-582. http://dx.doi.org/10.1111/j.1527-2001.2012.01280.x

Stolerman, Ian P. "Startle." Encyclopedia of Psychopharmacology. 2010. 1276. Print.

Tatum, Beverly Daniel. Why Are All the Black Kids Sitting Together in the Cafeteria: And Other Conversations about Race. New York, NY: Basic Books, 2003. 


\section{Acknowledgments}

This publication was produced with support from the staff of the Billy Ireland Cartoon Library \& Museum, the Libraries Publishing Program, and the Libraries Exhibits Program, with help from colleagues in the Copyright Resources Center, Communications Department, and Information Technology.

The editors would like to thank the outside readers for their time and excellent feedback. Their input made these already excellent contributions even more insightful. 